\title{
EXPLORING THE ANALOGY BETWEEN MODERN TRAFFICKING IN HUMANS AND THE TRANS- ATLANTIC SLAVE TRADE
}

\author{
Karen E. Bravo*
}

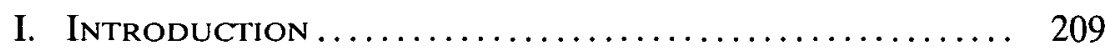

II. An Overview of the Trans-Atlantic Slave Trade, White Slavery, and Modern Trafficking in

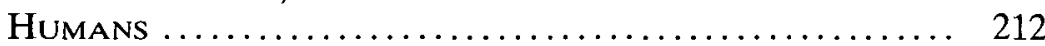

A. The Trans-Atlantic Slave Trade ................ 213

B. White Slavery ........................... 215

C. Modern Trafficking in Humans .................. 218

III. Combating Modern Trafficking in Humans:

Conceptual Frameworks..................... 221

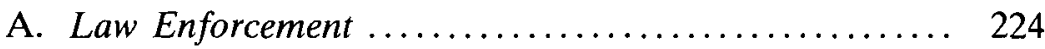

B. Human Rights........................... 230

C. Women's and Children's Rights ................ 232

D. Labor Rights ............................ 236

E. Another Voice: Market-Based Organizational Analysis . 238

F. Neo-Abolitionism........................... 240

IV. Analysis of the White Slavery and Trans-Atlantic Slave Trade Analogies and their Uses ............ 243

A. The White Slavery Analogy.................. 245

1. Media Reports and Commentary ............. 246

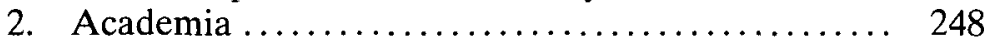

3. Legislation .............................. 249

B. The Trans-Atlantic Slave Trade Analogy ........... 250

1. Emotional Exhortation to Action ............ 251

* Assistant Professor of Law, Indiana University School of Law - Indianapolis; LLM New York University School of Law; JD Columbia University School of Law; BA University of the West Indies. Diane Amann, Janie Chuang, Paul Finkelman, Kevin R. Johnson, María Pabón López, Mary Harter Mitchell, James P. Nehf, Florence Wagman Roisman, and R. George Wright generously provided comments on earlier drafts. I am grateful for the comments and suggestions of the participants at the works in progress sessions at LatCrit XII in September 2006 and at the joint Association of American Law Schools/American Society of International Law MidYear Meeting in June 2007, and to my colleagues at Indiana University School of Law - Indianapolis who attended the March 2007 Faculty Colloquium. Reference Librarian, Debra Denslaw was invaluable in tracking down critical sources. Taffie R. Jones, Yvette LaPlante and April Shaw provided research assistance. 
2. Diminution of the Horror of Trans-Atlantic

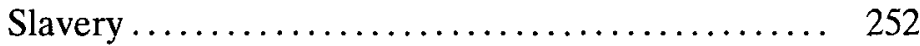

3. Assumption of the Mantle of Righteousness...... 254

4. Distancing Our (Enlightened) Time from Theirs or "How Far We've Come" ................... 256

5. Superficiality of the Uses Made of the TransAtlantic Slave Trade Analogy ............... 257

C. The Analogies Offer Much More ............... 259

V. A Perpetual Institution? Exploring the TransAtlantic Slave Trade Analogy ................ 260

A. Defining Slavery.......................... 260

1. International Law Definitions ............. 262

2. U.S. Domestic Law Definitions.............. 263

B. Comparative Analysis of Trans-Atlantic Slavery and Modern Traffic in Humans.................. 265

1. Legal Status of Slavery .................. 266

2. Status of the Slave ................... 269

3. Economic Structure ................... 280

4. State Complicity ..................... 291

VI. Conclusion: Beyond Neo-Abolitionism ........... 293

[I]ronically, there are more slaves now than there were even at the height of the transatlantic slave trade. ${ }^{1}$

We must show new energy in fighting back an old evil. Nearly two centuries after the abolition of the transatlantic slave trade, and more than a century after slavery was officially ended in its last strongholds, the trade in human beings for any purpose must not be allowed to thrive in our time. ${ }^{2}$

Apologists for the trans-Atlantic slave trade of yesteryear advocated for better ventilation and mattresses on ships for slaves, but all the regulation in the world would not have changed the fact that people used as slaves deserved freedom. The children and women of today deserve freedom too. ${ }^{3}$

1 Susan Llewelyn Leach, Slavery is Not Dead, Just Less Recognizable, CHRISTIAN SCi. Monitor, Sept. 1, 2004, at 16.

2 President George W. Bush, Speech Made Before the United Nations, General Assembly in New York (Sept. 23, 2003) (transcript available at http://www.white house.gov/news/releases/2003/09/20030923-4.html).

3 John R. Miller, Letter to the Editor, The Slavery of Prostitution, N.Y. TimEs, Dec. 20, 2005, at $\mathrm{A} 30$. 


\section{INTRODUCTION}

According to varied and sometimes conflicting sources, ${ }^{4} 27$ million people worldwide are enslaved, 4 million or 600,000 to 800,000 individuals are trafficked annually across international borders, ${ }^{6}$ and each year 14,000-17,500 people are trafficked into the United States. ${ }^{7}$ The trade in human beings has significant ramifications for international human rights, international criminal law, and the global economy. ${ }^{8}$ Despite the expenditure of a great deal of intellectual, economic, psychological, and other resources to prevent and punish the traffic in human beings, the trade appears to grow in scope annually. ${ }^{9}$

The modern "re-emergence" 10 of trafficking in human beings and of slavery is said to be linked to the deepening interconnection among coun-

4 "Unverified statistics, such as the figure of US\$5 billion to US\$7 billion a year in commercial profit, have remained a standard feature [of the discussions about human trafficking]." Diana Wong, The Rumor of Trafficking: Border Controls, Illegal Migration, and the Sovereignty of the Nation-State, in ILlicit Flows and CRIMINAL Things 69, 76 (Willem van Schendel \& Itty Abraham eds., 2005).

5 See Kevin Bales, Disposable People: New Slavery in the Global Economy 8-9 (2004) [hereinafter Bales, Disposable People]. Alternatively, according to other sources, perhaps "only" 12 million are enslaved worldwide. See Ethan B. Kapstein, The New Global Slave Trade, Foreign AfF., Nov.-Dec. 2006, at 105.

6 See Women as Chattel: The Emerging Global Market in Trafficking, 1 GENDER Matters Q. 1, 1 (1999) (citing to United Nations 1997 calculations); U.S. DEP'T OF State, Trafficking in Persons Report, June 2006, at 6.

7 Kapstein, supra note 5, at 110 (discussing 2006 U.S. Department of Justice report). Earlier estimates had indicated that up to 50,000 people were trafficked into the United States. See Amy O'Neill Richard, International Trafficking in Women to the United States: A Contemporary Manifestation of Slavery and Organized Crime iii (1999) [hereinafter Richard, CIA Report] (copy available at http://www.cia.gov/csi/monograph/women/trafficking.pdf.).

8 As used herein with respect to human "merchandise", "trade" does not imply the imposition of customs duties or imposts, licenses, or other revenue raising governmental regulation such as those that accompanied the trans-Atlantic trade in Africans in earlier centuries.

9 See, e.g., U.S. Dep't of State, Trafficking in Persons Report, supra note 6. Pursuant to the Trafficking Victims Protection Act of 2000, Pub. L. No. 106-386 $\$ 2$ A, 114 Stat.1464 (2000) codified at 22 U.S.C. $\$ 7101$, the State Department is required to provide annual reports on the anti-trafficking efforts of all other countries. The State Department is also required to rank all countries listed and described in the report according to its determination of the adherence of those countries to the minimum standards provided for in the Trafficking Victims Protection Act. See Trafficking Victims Protection Act of 2000, 22 U.S.C. $\$ 7101 \S \S 6(\mathrm{e})(3)(\mathrm{A})$ and (B) (2000).

10 In reality, human trafficking has re-emerged only in the sense that it has reentered public consciousness. Slavery has always been a part of human existence and was not eliminated by the nineteenth century abolition of trans-Atlantic slavery. See, e.g., Suzanne Miers, Slavery in the Twentieth Century: The Evolution of a 
tries in the global economy, overpopulation (with its consequent production of disposable people), and the victims' economic and other vulnerabilities. ${ }^{11}$ A significant number of academics and commentators highlight the evolution of the attempts to deal with modern trafficking in humans from the international and domestic U.S. reactions to the white slavery ${ }^{12}$ hysteria of the late nineteenth and early twentieth centuries and the international instruments formulated to combat white slavery. ${ }^{13}$ Also, in response to the reported increase, some academics have explored the potential applicability of the Thirteenth Amendment of the U.S. Constitution. ${ }^{14}$ References and analogies to the trans-Atlantic slave trade ${ }^{15}$ are also made in government policy statements, in the literature analyzing the modern traffic in humans, and in other fora. ${ }^{16}$ While the trans-Atlantic slave trade analogy is most frequently invoked, it is the efforts to combat the white slavery of the late nineteenth and early twentieth centuries that are the progenitors of the dominant frameworks applied to the modern traffic in human beings.

The content of these analogies varies with the intent of their users. The "old slavery" is compared to the "new slavery" with respect to, for example, the egregiousness of abusive treatment of slaves, the level of interconnection of the modern trade with the world economy, or the race or ethnicity of the victims, in order to distinguish the new slavery from the old. The implicit or explicit hypothesis is that modern trafficking in humans is more widespread and awful, and involves more victims and

Global Problem 345-50 (2003) (discussing the abolition of legal slavery in Saudi Arabia in the 1960s).

11 See, e.g. Bales, Disposable People, supra note 5.

12 For a description of "white slavery," see infra Part II.B.

13 See, e.g., Janie Chuang, Redirecting the Debate Over Trafficking in Women: Definitions, Paradigms, and Contexts, 11 Harv. Hum. RTs. J. 65 (1998); Stephanie Farrior, The International Law on Trafficking in Women and Children for Prostitution: Making it Live Up to Its Potential, 10 Harv. Hum. RTs. J. 213 (1997); A. Yasmine Rassam, Contemporary Forms of Slavery and the Evolution of the Prohibition of Slavery and the Slave Trade under Customary International Law, 39 VA. J. INT'L L. 303 (1999).

14 See, e.g., John M. Cook, Involuntary Servitude: Modern Conditions Addressed in United States v. Mussry, 34 Cath. U. L. Rev. 153 (1984); Neal Kumar Katyal, Men Who Own Women: A Thirteenth Amendment Critique of Forced Prostitution, 103 Yale L.J. 791 (1993); Tobias Barrington Wolff, The Thirteenth Amendment and Slavery in the Global Economy, 102 CoLum. L. REv. 973 (2002); Kathleen A. McKee, Modern-Day Slavery: Framing Effective Solutions for an Age-Old Problem, 55 CATH. U. L. Rev. 141 (2005).

15 As used herein, the term "trans-Atlantic slave trade" also includes transAtlantic slavery, in which the trade itself was embedded and of which it formed an ineluctable part.

16 See, e.g., supra notes 1-3 and accompanying text; and discussion infra Part IV. 
human degradation, than did the trans-Atlantic slave trade. ${ }^{17}$ Other commentators analogize to the trans-Atlantic slave trade in order to emphasize the similarities between the two phenomena and to urge that likeminded people should rise up to end the appalling practice, much as was eventually done to end the trans-Atlantic trade. Still others invoke the trans-Atlantic slave trade to assume a mantle of self-righteousness, and distance themselves, their political and economic system, their state and its efforts, from the repugnant modern traffic in human beings.

Is the analogy to the trans-Atlantic slave trade and slavery relevant? Is it useful? Is it misused? Can it contribute to understanding of modern trafficking in humans or lead to mechanisms to combat human trafficking in the twenty-first century? In Analogies at War, Professor Yuen Foong Khong explained that historical analogies are often misused by policymakers and identified some reasons for that trend: firstly, "people tend to access analogies on the basis of surface similarities," 18 and secondly, human cognitive processes of knowledge acquisition and analysis. ${ }^{19}$ Further, Khong noted that

[T] he power of historical analogies is in part a function of how deeply ingrained they have become in the official and public mindset. When their lessons become part of the unspoken and spoken lore, when there is only one consensual interpretation, their premises and their relevance become matters of dogma that few will see fit to question. At that point, analogies step beyond their role as heuristic devices for discovering facts and explanations and assume the role of explanations and facts themselves. ${ }^{20}$

Similarly, the analogies to the trans-Atlantic slave trade in the antitrafficking discourse encapsulate a particular interpretation of the past, seek to project that interpretation onto the present, and extrapolate a too-constrained set of lessons.

It is my hypothesis that those who have used the analogy to date have failed to explore it more than superficially, or to adequately map out both the similarities and differences between the two systems of exploitation. As a consequence, the ability to effectively combat the modern traffic in human beings (or indeed, to combat the slavery - or exploitative or forced labor - of the estimated 27 million people reportedly held in slavery within state borders but not trafficked) ${ }^{21}$ has been compromised both internationally and domestically by a failure to recognize and act upon

17 See, e.g., Vatican Official Says Human Trafficking Now Is Worse than African Slave Trade, Nov. 14, 2006, available at http://www.iht.com/articles/ap/2006/11/14/ europe/EU_GEN_Vatican_Human_Trafficking.php; Bales, Disposable PeOPLE, supra note 5, at 8. See also discussion infra Part IV.

18 See Yuen Foon Khong, Analogies at War 14 (1992).

19 Id.

${ }^{20} \mathrm{Id}$. at 262.

21 Bales, Disposable People, supra note 5, at 8. 
the structural roots of the modern trade. The analogy is underutilized as currently employed because it does not illuminate essential similarities or differences shared by the modern traffic in humans and the trans-Atlantic slave trade. Instead, use of the analogy too often appeals to emotions in order to serve the particular ends of the user. ${ }^{22}$ However, the analogy to the trans-Atlantic slave trade can be relevant if explored more deeply there are similarities not merely in individual plights but in the deeper structures of the world economic system and the factors that caused and fostered the rise of both phenomena.

This Article examines some uses of the analogy to the trans-Atlantic slave trade in the modern anti-trafficking discourse and the impact of those uses, and maps out the characteristics that underlie and distinguish the trans-Atlantic slave trade and the modern traffic in humans to determine whether the trans-Atlantic slave trade offers a conceptual framework that may be used to effectively combat modern trafficking in humans. The thrust of the exploration and analysis conducted in this Article does not depend upon a determination that modern trafficking in persons is or is not slavery, modern slavery, or a modern form of slavery, since the criticism of the uses of the analogy to trans-Atlantic slavery and the shortcomings of the frameworks utilized to understand and combat the traffic in human beings does not depend on either such a semantic congruence or an attempt to assert ownership of the term "slavery."

Part II of this paper describes modern trafficking in humans, white slavery, and the trans-Atlantic slave trade. Part III discusses the frameworks and mechanisms currently deployed to combat modern trafficking in humans. Part IV interrogates the uses made of analogies to both white slavery and the trans-Atlantic slave trade in contemporary anti-trafficking discourse, and assesses the effects of the analogies. Part $\mathrm{V}$ compares and contrasts modern trafficking in humans and the transAtlantic slave trade, laying bare the fundamental similarities in their economic roles and their intricate intertwining in the economic systems of their times. The Article concludes that the analogy to the trans-Atlantic slave trade leads to a more comprehensive and potentially more effective mechanism for combating the modern trafficking in human beings than do the legal and conceptual frameworks currently employed.

\section{An Overview of the Trans-Atlantic Slave Trade, White Slavery, and Modern Trafficking in Humans}

Since the end of trans-Atlantic slavery, nation states and international institutions have recognized and committed to protecting fundamental rights of human beings. ${ }^{23}$ Recognition and protection of those rights

22 See discussion infra Part IV.

${ }^{23}$ Examples of such commitments include the Universal Declaration of Human Rights, Dec. 10, 1948, G.A. Res. 217(III)(A), U.N Doc. A/810 at 71; the International Covenant on Economic, Social and Cultural Rights, Dec. 16, 1966, 933 U.N.T.S. 3; 
would seem to make impossible a resurgence in the enslavement of human beings. Yet that resurgence has been documented worldwide. ${ }^{24}$

Combatants against the modern traffic in human beings seek understanding and weapons by looking toward previous periods of human enslavement. Two instances of enslavement which appear to be particularly relevant due to the global scope of their manifestation are the transAtlantic slave trade and the white slavery of the late nineteenth and early twentieth centuries.

\section{A. The Trans-Atlantic Slave Trade}

The Trans-Atlantic slave trade was born amidst the rush of European powers to exploit the "New World" discovered by Christopher Columbus. ${ }^{25}$ Introduced by the Portuguese and Spanish ${ }^{26}$ to replace the indigenous inhabitants of the Americas who were quickly falling prey to the colonists' depredations, diseases, and labor demands, the trans-Atlantic slave trade and African slavery quickly became the economic and social norm - an integral part of the exploration and settlement of the hemisphere. $^{27}$

Historians estimate that, from the 1400 s until Brazil ended its slave trade in 1888 (the last country in the hemisphere to do so), ${ }^{28} 9.5$ million Africans were shipped from Africa to the Americas and elsewhere. ${ }^{29}$ While the vast bulk of the enslaved Africans and their New World descendants were destined for agricultural labor on the plantations of Europe's Caribbean island colonies, Central and South America, and the United States, slave labor was used in all aspects of New World life. From farming to candle making, shipbuilding to furniture making, African slaves provided labor for their masters and the colonies' economies. ${ }^{30}$

and the 1966 International Covenant on Civil and Political Rights, Dec. 16, 1966, 999 U.N.T.S. 171.

${ }^{24}$ See, e.g., U.S. Dep't of State, Trafficking in Persons Report, supra note 6.

25 The traffic of African slaves to Europe and European territories (such as Madeira) preceded the trans-Atlantic trade. See David Brion Davis, Inhuman Bondage: The Rise and Fall of Slavery in the New World 84 (2006) [hereinafter Davis, Inhuman Bondage]; Sidney W. Mintz, Sweetness and Power: The Place of Sugar in Modern History 30-32 (1985).

26 Davis, Inhuman Bondage, supra note 25, at 98, 103.

27 Id. at 80-81; see also Peter Kolchin, American Slavery 4 (2003).

28 Davis, Inhuman Bondage, supra note 25, at 323-27, 238.

29 See James A. Rawley et al., The Transatlantic Slave Trade 16 (revised ed. 2005) (reporting, analyzing and presenting in table format the analyses conducted in 1968 by historian Philip D. Curtin and in 2001 by historian David Eltis, who estimated, respectively, that 9,556,000 and 9,599,000 Africans were transshipped across the Atlantic during the trans-Atlantic slave trade).

30 Davis, Inhuman Bondage, supra note 25, at 129. 
Following pitched political battles in Britain, the African slave trade was outlawed in the British Empire in 1807, effective January 1, 1808. ${ }^{31}$ Enshrined in and protected by the U.S. Constitution, ${ }^{32}$ the slave trade officially ended in the United States by Congressional legislation on the same date. ${ }^{33}$ Nevertheless, illicit trade from Africa and a newly resurgent internal trade in Africans continued in the continental United States. ${ }^{34}$

While its armies, navies, and diplomats worked to persuade other European powers to end the trade in Africans, ${ }^{35}$ amidst ardent and passionate conflict Great Britain proceeded to abolish slavery itself both domestically and throughout its empire. ${ }^{36}$ Final legal abolition throughout the British Empire came in $1838 .^{37}$ In 1865 , following attempted secession by its southern states and a bloody and brutal civil war, the United States ended the chattel slavery of blacks. ${ }^{38}$ By 1888 , when Brazil abolished slavery, the trade in enslaved Africans across the Atlantic and

31 Id. at 231-37. At least one other historian identifies the effective date of the abolition of the British slave trade as May 1, 1807. See Adam Hochschild, Bury the Chains: Prophets and Rebels in the Fight to Free An Empire's Slaves 307 (2005).

32 According to Article I, Section 9, clause 1 of the U.S. Constitution:

The Migration or Importation of such Persons as any of the States now existing shall think proper to admit, shall not be prohibited by the Congress prior to the Year one thousand eight hundred and eight, but a tax may be imposed on such Importation, not exceeding ten dollars for each Person.

U.S. Const. art. I, § 9, cl. 1.1. See Paul Finkelman, Slavery and the Founders: Race AND Liberty in the Age of JefFerson 3-36 (2001) (discussing the debate about slavery and the slave trade at the Constitutional Convention and the "dirty compromise").

33 An Act to Prohibit the Importation of Slaves into any Port or Place Within the Jurisdiction of the United States, From and After the First Day of January, in the Year of our Lord One Thousand Eight Hundred and Eight, enacted May 2, 1807, available at http://www.yale.edu/lawweb/avalon/statutes/slavery/sl004.htm. See also, DAvis, INHUMAN BONDAGE, supra note 25, at 237.

34 Id. at 183.

35 See MiERs, supra note 10 , at 14-19.

36 Davis, Inhuman Bondage, supra note 25 , at $237-38$; see generally Hochschild, supra note 31. Although Lord Mansfield's historic Somerset v. Steward (1772) decision is now generally believed to have forbidden slavery in England, the holding was, in fact, much more narrow, and slavery did continue to exist in England. See William M. Wiecek, The Sources of Antislavery Constitutionalism in AMERICA 1760-1848 20, 32 (1977). Within a short time after the opinion was issued in the popular mind it "burst the confines of its [holding]." Id. at 33. See also id. at 3437.

37 The British abolition of slavery was a two-step model, which included a mandatory period of "apprenticeship" for the newly freed slaves, and the payment of compensation to slaveholders. See David Brion Davis, Slavery and Human Progress 205 (1984) [hereinafter Davis, Slavery and Human Progress].

38 Davis, Inhuman Bondage, supra note 25, at 319-22. 
the institution of slavery were legally and officially "ended" in the Americas.

\section{B. White Slavery}

The phenomenon of and alarm about the enslavement of white women arose in Europe and the United States in the late nineteenth and early twentieth centuries. Historian Eileen Scully identified three interdependent developments that gave rise to, among other things, "an international traffic in sex workers" 39 in that period. First, Scully pointed to the abolition of the African slave trade and the deployment of replacement non-white indentured labor to now labor-poor plantation economies; the movement of white males seeking economic opportunities to colonial and Western-dominated enclaves; and the movement of non-white males from newly impoverished rural areas to those same colonial and Westerndominated enclaves. ${ }^{40}$ Second, Scully described the movement of both non-white and white sex workers to seek economic opportunities and fill the demand arising from those movements, as well as the rise of a "universal racialized sexual hierarch[y]" with white female sex workers at the apex. $^{41}$ Third, Scully asserted that while, for some women, in the early days of the international sex trade the decision to become sex workers was a result of economic, social, and cultural vulnerabilities brought about by far-reaching societal changes, ${ }^{42}$ for many Western women, confronting circumscribed choices for professional engagement, the decision to become sex workers overseas was a rational one founded on desire for economic advancement. ${ }^{43}$

In the 1890 s and beyond, as the number of white women engaged in sex work in the faraway colonies grew and the universal racial hierarchy took greater hold, their existence became an increasing affront to the public and legislators in metropolitan centers. ${ }^{44}$ Women from Western

39 See Eileen Scully, Pre-Cold War Traffic in Sexual Labor and Its Foes: Some Contemporary Lessons, in Global Human Smuggling 77 (David Kyle \& Rey Koslowski eds., 2001).

40 Id. at 75-77.

41 Id. at 77.

42 Id. at 78-79. See also Kamala Kempadoo, Introduction: From Moral Panic to Global Justice: Changing Perspectives on Trafficking, in TRAFFICKING AND Prostitution Reconsidered: New Perspectives on Migration, Sex Work, and Human Rights x (Kamala Kempadoo, Jyoti Sanghera \& Bandana Pattanaik eds., 2005).

43 Scully pointed out the later domination and degradation of indigenous and other non-white women as the trade was taken over by organized groups that often specialized in women from those groups' own communities. Scully, supra note 39, at 80-81 ("[A]n initial phase of agency and initiative among migratory Chinese and Japanese sex workers was quickly overtaken by more coercive, exploitative arrangements.")

44 Id. at $82-87$. 
Europe and the United States worked as prostitutes in South America, the Middle East, and Asia, ${ }^{45}$ and rumors of organized networks that procured, for instance, English girls for prostitution in France and Belgium, and the increased visibility of "migratory prostitution" led to greater public perception of an onslaught against the metropole's very identity. ${ }^{46}$ Scully pointed out that since the victimization of whites alone was targeted, leaving unchallenged the exploitation of non-white women, the racialized character of the fight against the eighteenth and early nineteenth century traffic helped undermine the effectiveness of the international instruments adopted to combat the trade by targeting only the sexual exploitation of a single racial group. ${ }^{47}$

Marlene D. Beckman ${ }^{48}$ and Eileen Scully provided descriptions of public attitudes on both sides of the Atlantic. Beckman noted that " $[t]$ he Progressive Era reformers who supported the [Mann] Act had used the words 'white slavery' to promote the vision of women held in bondage against their will, of mysterious druggings and abductions of helpless young girls, and of unexplained disappearances of innocent and naïve immigrants forced into lives of prostitutions and vice." 49 Scully reported that

By 1910, the image of the white slave trade conjured up by London purity groups had taken full hold of the American imagination. Lurid stories of sullied white womanhood and organized syndicates linking major cities helped bring on board southerners who otherwise would have argued states' rights in the face of a broad expansion of federal police powers. The vision of a vast network of Jewish and French procurers kidnapping and luring white women from Europe and America to service lowly natives and "eastern rich potentates" was captivating, combining as it did racial anxieties, colonial debates, immigration politics, and public morality issues. Similar sensationalism and bourgeois prurience was evident elsewhere, from London to Moscow to Buenos Aires. ${ }^{50}$

\footnotetext{
45 Id. at 78-79.

$46 \mathrm{Id}$. at 84 .

47 Id. at 86-87 ("Those who might have been able to shut down the traffic as completely as had been the African slave trade were white, metropolitan populations easily outraged by tales of their young pure women brought to the outposts of barely veiled barbarity.")

48 See Marlene D. Beckman, Note, The White Slave Traffic Act: The Historical Impact of a Criminal Law Policy on Women, 72 Geo. L.J. 1111 (1984).

49 See id. at 1111 (referring to the White-Slave Traffic (Mann) Act, ch. 395, 36 Stat. 825 (1910) (codified as amended at 18 U.S.C. $\$ \$ 2421-2424$ (2000)).

50 Scully, supra note 39, at 86 (citations omitted). As discussed in Part IV infra, the reported public sentiments are reminiscent of the reactions to the modern traffic in humans.
} 
While scholars now agree that white slavery existed more in public perception than in reality, ${ }^{51}$ a number of international instruments and domestic statutes were adopted by the United States and European countries in response. The bi-Atlantic fear that white women were being sold into slavery to non-white males gave rise to the 1904 International Agreement for the Suppression of the White Slave Trade. ${ }^{52}$ As revealed by the very name of the agreement, it was the enslavement of white women, alone, that was its target. Pursuant to the provisions of the treaty, victims would be protected, while those who seduced them into prostitution would be punished. ${ }^{53}$ After the 1904 Act proved largely ineffective, the International Convention for the Suppression of White Slave Traffic was adopted in $1910 . .^{54}$ The two international instruments, together with two later treaties addressing the trafficking of women and children of all races (the International Convention for the Suppression of the Traffic in Women and Children ${ }^{55}$ and the International Convention on the Suppression of the Traffic in Women of Full Age), ${ }^{56}$ were consolidated by the League of Nations to produce the Convention for the Suppression of the Traffic in Persons and of the Exploitation of the Prostitution of Others. ${ }^{57}$ In the United States, Congress passed the White Slave Traffic Act (the Mann Act), imposing felony liability for the transportation of women across internal, i.e., interstate, or international borders for "the purpose of prostitution or debauchery or any other immoral purpose." 58

51 See id. at 87 (reporting that $99 \%$ of traffic victims were non-white women). Experts believe that the economic conditions of the time, which had propelled large numbers of women to work outside the home for the first time, gave rise to the perception, which was widely held on both sides of the Atlantic. See, e.g., David J. Langum, Crossing Over the Line: Legislating Morality and the Mann Act 16-17 (1994).

52 International Agreement for the Suppression of White Slave Traffic, May 18, 1904, 35 Stat.1979 1 L.N.T.S. 83.

53 Id.

54 International Convention for the Suppression of the White Slave Traffic, May 4, 1910, 211 Consol. T.S. 45, 103 B.F.S.P. 244.

55 International Convention on the Suppression of the Traffic in Women and Children, Sept. 30, 1921, 9 L.N.T.S. 416.

56 International Convention for the Suppression of the Traffic in Women of Full Age, Oct. 11, 1933, 150 L.N.T.S. 431.

57 Convention for the Suppression of the Traffic in Persons and of the Exploitation of the Prostitution of Others, Dec. 2, 1949, 96 U.N.T.S. 271. See Farrior, supra note 13 at 216-223 (discussing the treaties).

58 White-Slave Traffic (Mann) Act, ch. 395, 36 Stat. 825 (1910) (codified as amended at 18 U.S.C. $\$ \S 2421-2424$ (2000)). Commentator Marlene D. Beckman noted that:

[T] he Act was so named because its central purpose was to halt what many believed was a serious and widespread practice: Commercial procurers taking innocent young girls and women by force and holding them captive with threats 


\section{Modern Trafficking in Humans}

In the late 1980 s and into the 1990 s the issue of trafficking in human beings emerged in the consciousness of policymakers and the public. Growing numbers of victims were being enslaved by modern-day traffickers: tricked by schemes offering employment abroad or other prospects of fruitful economic opportunities, or simply sold by parents or other authority figures, men, women, and children around the world were being subjected to sexual or other exploitation without compensation. ${ }^{59}$ Transported across international borders, victims were deprived of freedom of movement, raped, beaten, and violated in various ways through the mechanisms of violence, force, psychological abuse, and fraud. By the late 1990s, conventional knowledge held, based on varying statistical sources, that up to four million people were trafficked annually across national borders, ${ }^{60}$ that 27 million individuals were held in some form of involuntary servitude or peonage, ${ }^{61}$ and that the trade in humans was a $\$ 5$ to $\$ 7$-billion-per-year industry, ${ }^{62}$ less profitable than only the traffic in

to their lives, a practice that resembled black servitude in its exploitative and barbarous nature.

See Beckman, supra note 48, at 1112 (emphasis added). Beckman discussed the legislative history of the Mann Act and the moral policing function to which it was later put. See id. passim. For example, it was the Mann Act that was used to prosecute black heavyweight champion, Jack Jackson, whose marriage to a white woman and sexual liaisons with other white females had transgressed the taboos of his era. See Kevin Johnson, Book Review, The Legacy of Jim Crow: The Enduring Taboo of Black-White Romance, 84 Tex. L. Rev. 739, 752 (2006). The statute was used to prosecute black men who engaged in liaisons with white women, even if the women were their fiancées and they were crossing state borders in order to marry. See RaCHEL F. Moran, Interracial Intimacy: The Regulation of Race and Romance 67 (2001). See also LANGUM, supra note 51, passim, for description and analysis of the social, economic, and political forces that influenced and determined the passage of the Mann Act and its implementation in policing morality in the United States.

59 See, e.g., Associated Press, Man Pleads Guilty to Enslaving Women, LAs VEgas Rev.-J., Dec. 4, 1999 at 3A; Kate Connolly, Czechs Struggle to Curb Sex Tourism, Globe And MaIl (Toronto), Jan. 16, 1999, at A13; Brian D. Crecente, Sex-Slave Ringleader Admits Role, PAlm BeACH Post, Jan. 16, 1999, at 1B; Peter Chen, Australia Aims to Eradicate Asian Sex Slave Trade, Central News Agency (Taiwan), January 5, 1999; John Barry, Tortured Au Pair Finds A New Life, Miami Herald, July 31, 1998, at 1B; Kieran Nicholson \& Sheba R. Wheeler, 3 Held in Alleged Sex-Slave Ring, Denver Post, Nov. 13, 1998, at B-02; Triads Taking Women to UK for Prostitution, South China Morning Post, Aug. 14, 1997, at 7 [hereinafter, collectively, Media Reports].

60 See Women as Chattel, supra note 6, at 1.

61 Bales, Disposable People, supra note 5, at 8.

62 Wong, supra note 4 , at 76. 
illegal drugs and arms. ${ }^{63}$ In addition, 50,000 persons were said to be trafficked annually into the United States. ${ }^{64}$

By 2006 , official figures regarding the scope of the modern traffic had substantially declined from those released among the first alarums about the trade. The U.S. State Department Trafficking in Persons Reports for the years 2004, 2005, and 2006 consistently have estimated the number of persons trafficked across international borders at 600,000 to $800,000 .^{65}$ The U.S. Attorney General's annual report to Congress released in June 2006 noted that between 14,500 and 17,500 victims were imported annually into the United States, a more than $60 \%$ decline from the prior estimates. ${ }^{66}$ Only a month later, the July 2006 Government Accountability Office report on the United States' anti-trafficking strategy pointed to significant methodological flaws and challenges in the collection of data regarding the modern traffic in humans and questioned the validity of the statistics disseminated through the U.S. Department of State's (State Department) annual Trafficking in Persons Reports and other mechanisms. ${ }^{67}$ The GAO Report seriously questioned the scope of the modern traffic in human beings as currently depicted, noting, among other things, discrepancy between the official estimates of the trade and the number of victims actually assisted worldwide or within the United States. ${ }^{68}$

While the development of consensus that the modern traffic in human beings may exploit fewer victims than was generally believed in the 1990s is cause for joy, it does give rise to the question why the problem initially may have been over-reported. Two contrasting accounts of the emergence of broad awareness of the trade and the development of an international consensus to combat it are illuminating. Commentators such as Kelly Hyland pointed to growing international appreciation of and con-

63 See Susan Tiefenbrun, The Saga of Susannah, A U.S. Remedy for Sex Trafficking in Women: The Victims of Trafficking and Violence Protection Act of 2000, 2002 UTAH L. Rev. 107, 140 (2002) (citing to congressional testimony of the Assistant Secretary of State for Democracy, Human Rights and Labor).

64 See Richard, CIA RePort, supra note 7, at 3.

65 See U.S. Dep't of State, Trafficking in Persons Report, 2004, at 6; U.S. Dep't of State, Trafficking in Persons Report, 2005, at 6; U.S. Dep't of State, Trafficking in Persons Report, 2006, supra note 6, at 6.

66 See Attorney General's Annual Report to Congress on U.S. Government Activities to Combat Trafficking in Persons Fiscal Year 2005 3 (2006) [hereinafter 2006 Attorney General Report]. That decline may reflect changes in information-gathering methodologies rather than a decrease in the scope of the traffic in human beings.

67 U.S. Gov't Accountability Office, Human Trafficking: Better Data, Strategy, and Reporting Needed to Enhance U.S. Antitrafficking Efforts ABROAd 10-17 (2006) [hereinafter 2006 GAO RePORT].

${ }^{68}$ Id. at 17; see also Kempadoo, supra note 42, at xix ("Many of the claims made about trafficking are unsubstantiated and undocumented, and are based on sensationalist reports, hyperbole, and conceptual confusions ...."). 
cern regarding the scope, complexity, and criminality of modern trafficking in humans as the impetus for the development and adoption of the United Nations anti-trafficking treaty in $2000 .^{69}$ Hyland identified the human rights abuses inflicted by traffickers on their victims as the central concern. ${ }^{70}$ In contrast, other scholars have highlighted states' growing realization of and concern regarding the threats to their sovereignty presented by modern trafficking in humans. ${ }^{71}$ For example, Anne Gallagher pointed to a widespread state concern regarding the threat of illegal and unregulated immigration, ${ }^{72}$ while Diane Wong located European alarm about human trafficking that arose in the period following the fall of the Berlin Wall within broader European fears of being inundated by migrants from the former Soviet Bloc. ${ }^{73}$

Given general knowledge that child trafficking and debt bondage, ${ }^{74}$ for example, have always existed and continued to exist even after the aboli-

69 See Kelly E. Hyland, The Impact of the Protocol to Prevent, Suppress and Punish Trafficking in Persons, Especially Women and Children, 8 HuMAN RIGHTS BRIEF 30 (Winter 2001). See infra note 88 and accompanying text for discussion and definition of the Trafficking Protocol.

70 According to Hyland, five factors contributed to the development of the protocol: (1) non-governmental organizations (NGOs) worldwide lobbied governments on behalf of trafficking victims; (2) projections that the number of victims would continue to rise in conjunction with rising migration, and therefore should be curbed; (3) nations viewed trafficking as not only a human rights issue, but also as an issue of transnational organized crime that required a global response; (4) governments grappled with prosecuting trafficking cases in the absence of trafficking laws; and (5) the existing body of international trafficking law was inadequate as a tool to combat trafficking. Id. at 30-31.

${ }^{71}$ See, e.g., Wong, supra note 4, at 74:

[T]he conjunction of trafficking and illegal immigration materialized into the political consciousness of Europe at the 11th International Organization for Migration (IOM) Seminar, devoted to the theme of "Global Human Trafficking" in 1994. In an influential paper presented to that conference by a leading European scholar on international migration, the emergent model of the new unholy trinity threatening the borders of Europe-trafficking, illegal immigration, and organized crime-was introduced and authoritatively quantified.

See also Anne Gallagher, Human Rights and the New UN Protocols on Trafficking and Migrant Smuggling: A Preliminary Analysis, 23 Hum. RTs. Q. 975, 976 (2001) ("While human rights concerns may have provided some impetus (or cover) for collective action, it is the sovereignty/security issues surrounding trafficking and migrant smuggling which are the true driving force behind such efforts.").

72 Gallagher, supra note 71, at 976 ("Wealthy states are increasingly concerned that the actions of traffickers and migrant smugglers interfere with orderly migration and facilitate the circumvention of national immigration restrictions.").

73 Wong, supra note 4 , at $74-75$.

${ }^{74}$ Debt bondage is a form of exploitation by which an individual's labor is appropriated to "pay off" a debt (real or purported) that is virtually impossible to repay, due to the low wages and/or the imposition of interest and additional 
tion of the trans-Atlantic slave trade ${ }^{75}$ there are three additional compelling and potentially complementary interpretations of the flurry of activity leading to the international convention adopted in 2000 . First, the attainment of a level of human progress and acceptance of the norm against slavery inevitably led to the determination to stamp out the continuing blight. Second, the perceived sharp increase in the illicit traffic, together with the types of victims (Eastern Europeans who are perceived as white) and the importation of the practices into the very heart of the West stimulated the strong reaction. Third, the end of the Cold War may have freed state resources to combat a previously identified blight for which resources and the potential for international cooperation previously were unavailable.

Confronted with evidence of the increase in the traffic and exploitation of human beings and violations of state borders and laws, scholars, policymakers, NGOs, and legislators came together in both the international and domestic U.S. arenas to combat human trafficking.

\section{Combating Modern Trafficking in Humans: CONCEPTUAL FramewORKS}

The specter of involuntary sex and of despoilment of innocent white maidens seized the world's attention in the late 1800 s and early 1900 s. Overtones of that appalled, fascinated, and condemnatory prurience continue to pervade public and institutional perceptions of the traffic in human beings in the early twenty-first century. ${ }^{76}$ The focus on innocent women and children and on the illicit sex foisted upon them draws the attention of policymakers, academics, and the public from the systemic reality of the traffic in humans, leading to reification of the perception of traffickers as aberrant (in)human beings and the failure to appreciate that traffickers, like their victims, are cogs in a vast and interconnected economic machine ${ }^{77}$ in which we all are complicit. ${ }^{78}$ Thus it is that the mod-

indebtedness (sometimes for items whose costs are assessed at more than market value).

75 See, e.g., notes 81 and 82 infra.

76 See, e.g., Senator Paul Wellstone, Remarks on the Senate floor in discussions preceding passage of the Trafficking Victims Protection Act. Trafficking Victims Protection Act of 2000 (transcript available through Lexsee 146 Cong. Rec. S.). Despite his acknowledgement that some victims were destined for sweatshops and other types of forced labor, Senator Wellstone's proffered examples of trafficking victims centered on women and young girls who had been sexually enslaved, some in the United States.

${ }^{77}$ To the contrary, the economic gains accruing from the enslavement and trafficking of others are spread throughout the society and economy. The economic benefits of trafficking to society as a whole and to individual states were noted by Professor Nora Demleitner in her 1994 article on modern trafficking. See Nora V. Demleitner, Forced Prostitution: Naming an International Offense, 18 FordHAM INT'L L.J. 163, 189 (1994) ("Trafficking in women has become a huge international business 
ern fight against human trafficking, including commentary, analysis, and would-be legislative solutions bears the imprint of the "iconic victim."79 As a result, it is from the legislative weapons of the early twentieth century that the weapons of the twenty-first have evolved. ${ }^{80}$

that brings immense economic benefits to everyone involved except the women forced to work as prostitutes."). Venturing to more specifically identify the beneficiaries of the trade, Demleitner notes that

In addition to the tourist agencies, hotels, and transportation services, the police and the government bureaucracy all benefit directly or indirectly from forced prostitution which has turned into a large industry. In some countries, such as Thailand, government officials and the local elites have come to accept ... forced prostitution because they view the practice as the key to regional development and an important source of foreign currency.

Id. at 190 (emphasis added) (internal footnote omitted). See also, Saskia Sassen, Women's Burden: Counter-Geographies of Globalization and the Feminization of Survival, 71 Nordic J. INT'L L. 255, 268-70 (2002) (describing the increasing role of women and their exploitation in the economic development strategies of poorer countries); Louise Shelley, Trafficking in Women: The Business Model Approach, Brown J. OF World AFF. Summer/Fall 2003, at 119, 125.

The investment patterns of the traffickers resembled those of people who were smuggled rather than those of drug traffickers. Just as individuals smuggled to the United States return their salaries to buy land and build and improve homes, the traffickers followed the same pattern on a large scale. They could buy millions of dollars worth of farms with the enormous profits made from trafficking even a relatively small number of women.

See also Peter Andreas, The Transformation of Migrant Smuggling Across the U.S.Mexican Border, in Global Human Smuggling 117 (David Kyle \& Rey Koslowski eds., 2001) ("As one smuggler explained, 'Figure it this way. If I work in a factory five days, I make $\$ 125$ a week. If I take one person across the border, I get $\$ 300$.'”).

78 See, e.g., David Batstone, From Sex Workers to Restaurant Workers, the Global Slave Trade is Growing, AlterNet, March 15, 2007, available at http://www.alternet. org/story/48951

We may not even realize how each one of us drives the demand during the course of a normal day. Kevin Bales, a pioneer in the fight against modern slavery, expresses well those commercial connections: "slaves in Pakistan may have made the shoes you are wearing and the carpet you stand on. Slaves in the Caribbean may have put sugar in your kitchen and toys in the hands of your children."

79 See, e.g., Jayashri Srikantiah, Perfect Victims and Real Survivors: The Iconic Victim in Domestic Human Trafficking Law, 87 B.U. L. Rev. 157, 187 (2007).

80 See, e.g., Peter Andreas \& Ethan Nadelman, Policing the Globe: Criminalization and Crime Control in International Relations 36 (2006) ("Intense media coverage and activism by governmental and nongovernmental organizations have drawn enormous attention to sex trafficking in recent years, leading to a flurry of new international criminalization initiatives that very much echo the earlier debates and moralizing rhetoric about white slavery.") (emphasis added). Similarly, just as the scope of the nineteenth century white slavery is now questioned, the contraction in the number of estimated trafficked victims may reflect an initial hysteria about the widespread scope of the modern phenomenon. See, e.g., 2006 GAO REPORT, supra note 67, at 2, 10-18 (discussing, among other things, the challenges of and flaws in data collection methodology, unreliability of the data, and 
The UN Working Group on Contemporary Forms of Slavery first raised the issue of sex tourism in its 1978 report, ${ }^{81}$ and the existence of international sex markets was generally known through media reports and other information channels. ${ }^{82}$ However, not until the 1990 s did modern trafficking in humans first begin to impinge on the consciousness of the Western public. ${ }^{83}$ A perceived growth in the buying and selling of human beings followed the collapse and dissolution of the Soviet Union. ${ }^{84}$ Media and other reports disseminated frightening statistics and horrific tales of the purchase and sale of, in particular, women and young girls from the former Soviet Union into Western Europe. ${ }^{85}$ The images of forced sexual slavery on a large scale rang alarm bells around the world. The human rights violations and the victimization of women and children affronted developed world concepts of where, what and who human beings had become in the post-World War II and post-Cold War era, in light of the era's flourishing legal recognition and protection of human rights.

The role of a conceptual framework is to create a mechanism for understanding, interpreting, and explaining a phenomenon. In addition, a framework is a mechanism for dealing with (whether through acceptance or targeted interventionist strategies) that phenomenon. Diagnosis, understanding, and mechanisms for dealing with the phenomenon create multiple feedback effects, as more complete understanding leads to more effective combat or more peaceful co-existence. International mechanisms and instruments utilized to combat human trafficking include both those specifically created for the purpose of confronting the "new" inter-

the fall in the estimated numbers of trafficking victims since 2000). The initial hysteria may have stemmed from and lead to the conflation of trafficking with prostitution, with a consequent over-counting of the number of estimated victims.

81 MiERs, supra note 10, at 429 ("Sex tourism was first raised at the [UN] Working Group in 1978. By 1989, it was rife in the Philippines, Sri Lanka, Thailand, and Taiwan, and by 1996, it was active in Brazil.").

82 See, e.g., Paul Handley, The Lust Frontier, FAR E. ECon. Rev. (Nov. 2, 1989); Steven Erlanger, Thriving Sex Industry in Bangkok Is Raising Fears of an AIDS Epidemic, N.Y. Times, March 30, 1989; Marline Simons, The Littlest Prostitutes, N.Y. Times, Jan. 16, 1994. See, also, Shelley, supra note 77, at 119 ("Although 'sexual trafficking' has been a long-standing phenomenon in Asia, it has spread to many areas of the world."); Kempadoo, supra note 42, at vii ("Human trafficking exploded into the public consciousness at the start of the twenty-first century, yet it is not a new issue and has been a global concern since the mid-nineteenth century."), xi (describing the issue of trafficking as "integral" to the international women's movement by 1985).

83 See, e.g., Media Reports, supra note 59.

84 Wong, supra note 4. See also ANDREAs \& Nadelman, supra note 80, at 34.

85 See, e.g., Gillian Caldwell et al., Global Survival Network, Crime and Servitude: An Expose of the Traffic in Women for Prostitution from the Newly Independent States (1997) (available in Trends in Organized Crime, Summer 1998). 
national traffic and those targeted at other ills and now pressed into service to combat the modern traffic in humans. All fall within at least one of the conceptual and legal frameworks utilized and deployed to foster understanding of and combat the modern trafficking of human beings: law enforcement, human rights, women's and children's rights, and labor rights. ${ }^{86}$ Of these, the law enforcement framework is predominant both internationally and in the United States.

\section{A. Law Enforcement}

The law enforcement framework for interpreting and combating human trafficking is the most pervasive and broadly accepted. ${ }^{87}$ Components of this framework can be found in a number of international and domestic instruments. It is through this prism that the UN Protocol to Prevent, Suppress and Punish Trafficking in Persons, Especially Women and Children, Supplementing the United Nations Convention Against Transnational Organized Crime (hereinafter, the Trafficking Protocol) ${ }^{88}$ was adopted and ratified as a protocol to the more wide-ranging Convention Against Transnational Organized Crime. ${ }^{89}$ United by the threats to nation state sovereignty ${ }^{90}$ presented by the perceived surge in trafficking conducted by criminal networks, UN member states quickly adopted

${ }^{86}$ See generally Elizabeth M. Bruch, Models Wanted: The Search for An Effective Response to Human Trafficking, 40 STAN. J. INT'L L. 1 (2004). A fifth conceptual framework proffered by anti-trafficking scholar Louise Shelley has not yet been transposed into domestic legislation or international treaty instruments. See infra Part III.E for discussion of Professor Shelly's analytical framework.

87 One commentator points out that even "[a]ll existing international [labor] agreements that address human trafficking in detail take a law enforcement approach to the problem." See Anna Zalewski, Note, Migrants for Sale: The International Failure to Address Contemporary Human Trafficking, 29 Suffolk Transnat'L L. Rev. 113, 129 (2005).

88 Protocol To Prevent, Suppress and Punish Trafficking in Persons, Especially Women and Children, Supplementing the United Nations Convention Against Transnational Organized Crime, G.A. Res. 25, annex II, U.N. GAOR, 55th Sess., Supp. No. 49, at 60, U.N. Doc. A/45/49 (Vol. I) (2001), entered into force Sept. 9, 2003. [hereinafter Trafficking Protocol].

89 United Nations Convention Against Transnational Organized Crime, G.A. Res. 25, annex I, U.N. GAOR, 55th Sess., Supp. No. 49, at 44, U.N. Doc. A/45/49 (Vol. I) (2001), not in force [hereinafter UN Organized Crime Convention, or UN Convention].

90 Dimitri Vlassis, then-Secretary, Ad Hoc Committee for the Negotiation of the United Nations Convention Against Transnational Organized Crime, explained that, among member state concerns that led to drafting and adoption of the Convention and its protocols, the threat to sovereignty was predominant: "Dominant among the concerns remains safeguarding sovereignty, which is ... the last bastion of national integrity and identity." Dimitri Vlassis, The United Nations Convention Against Transnational Organized Crime and Its Three Protocols: Development and Outlook 2 (unpublished paper, on file with the author). Vlassis also asserted: "Crime as business 
both the UN Transnational Organized Crime Convention and the Trafficking Protocol in $2000 .^{91}$

One of the principal achievements of the Trafficking Protocol is the first international definition of trafficking. The Trafficking Protocol defines trafficking in persons as:

[T] he recruitment, transportation, transfer, harbouring or receipt of persons, by means of the threat or use of force or other forms of coercion, of abduction, of fraud, of deception, of the abuse of power or of a position of vulnerability or of the giving or receiving of payments or benefits to achieve the consent of a person having control over another person, for the purpose of exploitation. Exploitation shall include, at a minimum, the exploitation of the prostitution of others or other forms of sexual exploitation, forced labour or other services, slavery or practices similar to slavery, servitude or the removal of organs. ${ }^{92}$

Further, consent of the victim to his or her exploitation is irrelevant, ${ }^{93}$ while the "recruitment, transportation, harbouring or receipt of a child for the purpose of exploitation" is defined as trafficking in persons, even if the means set forth in Article 3(a) (quoted above) are not used. ${ }^{94}$

Pursuant to the UN Organized Crime Convention and the Trafficking Protocol, trafficking is or will be criminalized in all states that are party to the instruments when: first, the offense rises to the level of a "serious crime" (as defined in the Convention); second, the offense is "transnational" in nature; and third, the offense involves an organized criminal group. ${ }^{95}$ The Convention defines a "serious crime" as "conduct constituting an offence punishable by a maximum deprivation of liberty of at least four years or a more serious penalty."96 An "organized criminal group" is defined as "a structured group of three or more persons, existing for a

was recognized to pose a more serious threat to society and national economies than traditional forms of crime." Id. at 2 (emphasis added).

91 See Janie Chuang, The United States As Global Sheriff: Using Unilateral Sanctions to Combat Human Trafficking, $27 \mathrm{MICH}$. J. INT'L L. 437, 442 (2006) (noting that " $t]$ he United States introduced the first draft of the trafficking protocol in January 1999 and, less than two years later, the General Assembly adopted the [Trafficking] Protocol.") Four offences are established by the Convention: "(a) participation in an organized criminal group; (b) money laundering; (c) corruption; and (d) obstruction of justice." Vlassis, supra note 90, at 21. As of October 2007, 147 states were parties to the UN Organized Crime Convention. See www.unodc.org/ unodc/crime-cicp-signatures.htmi.

${ }^{92}$ See Trafficking Protocol, supra note 88, at art. 3(a).

93 See id. at art. 3(b).

94 The Trafficking Protocol defines "child" as "any person under eighteen years of age." See id. at art. 3(d).

95 See UN Organized Crime Convention, supra note 89, at art. 3 (scope of application).

96 See id. at art. 2(b). 
period of time and acting in concert with the aim of committing one or more serious crimes or offences established in accordance with this Convention, in order to obtain, directly or indirectly, a financial or other material benefit." 97 Therefore, incidents of trafficking involving the coordination of three or more persons and crossing international borders fall within the purview of the UN Organized Crime Convention and the Trafficking Protocol. The broad definition of the two terms makes clear the instruments' coverage of crimes formerly subject to purely domestic jurisdiction. Internationally criminalized, those activities now will be subject to international prosecution and cooperation, and to other obligations of the state parties to the instruments.

The obligations undertaken by member states pursuant to the UN Organized Crime Convention and the Trafficking Protocol include the criminalization of trafficking through the adoption of new laws that include the elements agreed to in the Protocol, ${ }^{98}$ international cooperation and information sharing, ${ }^{99}$ and repatriation of victims of trafficking. ${ }^{100}$ The Trafficking Protocol also includes exhortations regarding the treatment of victims, including non-criminalization of their actions. ${ }^{101}$ Dimitri Vlassis, in his description of the procedures and issues that led to

97 See id. at art. 2(a).

98 See id. at art. 5.1 ("Each State Party shall adopt such legislative and other measures as may be necessary to establish as criminal offences [participation in an organized criminal group].") and Trafficking Protocol, supra note 88, at art.5.1 ("Each State Party shall adopt such legislative and other measures as may be necessary to establish as criminal offences [trafficking in persons].").

99 See, e.g., UN Organized Crime Convention, supra note 89, at art. 18 ("States parties shall afford one another the widest measure of mutual legal assistance in investigations, prosecutions and judicial proceedings in relation to the offences covered by this Convention ..."); Trafficking Protocol, supra note 88, at art. 10.1 ("Law enforcement, immigration or other relevant authorities of States Parties shall, as appropriate, cooperate with one another by exchanging information, in accordance with their domestic law, to enable them to determine [the legality and legitimacy of persons and documents crossing borders]"); see also Trafficking Protocol, supra note 88 , at art. 11, 12 (addressing other law enforcement and border control cooperation obligations).

100 See Trafficking Protocol, supra note 88, at art. 8.1 ("The State Party of which a victim of trafficking in persons is a national or in which the person had the right of permanent residence at the time of entry into the territory of the receiving State Party shall facilitate and accept, with due regard for safety of that person, the return of that person without undue or unreasonable delay.").

101 See, e.g., Trafficking Protocol, supra note 88 at art. 2(b) ("The purposes of this Protocol are ... [t]o protect and assist the victims of such trafficking, with full respect for their human rights."); id., at art. 6.3 ("Each State Party shall consider implementing measures to provide for the physical, psychological and social recovery of victims of trafficking in persons, including in appropriate cases . . . and in particular, the provision of appropriate housing ...."). See also Trafficking Protocol, supra note 88 , at art. 7 (addressing the status of trafficked persons in receiving states.) 
the adoption of the instruments, and Dr. Anne Gallagher, then affiliated with the UN High Commissioner for Human Rights, in her perceptive analysis of the UN Trafficking Protocol, ${ }^{102}$ described the struggle between law enforcement and human and women's rights concerns in the drafting process. Both commentators reported that the law enforcement and border security concerns predominated.

The UN Organized Crime Convention's focus on protecting the integrity of state borders and territory is evidenced by the way in which human trafficking and migrant smuggling are treated. Despite the intimate relationship between human trafficking and migrant smuggling, both international and domestic efforts continue to treat the two as very dissimilar issues. Pursuant to the Protocol Against the Smuggling by Land, Sea and Air, supplementing the UN Convention Against Transnational Organized Crime ("Migrant Smuggling Protocol"), ${ }^{103}$ migrant smuggling is defined as "the procurement, in order to obtain, directly or indirectly, a financial or other material benefit, of the illegal entry of a person into a State Party of which the person is not a national or a permanent resident."104 As defined by the two Protocols (both of which were opened for signature simultaneously with the Organized Crime Convention), migrant smuggling involves the movement of a person across state borders, while trafficking does not. ${ }^{105}$ In addition, the exploitation purpose built into the trafficking definition appears to distinguish trafficking from migrant smuggling. Yet, an individual may consent to being trafficked, and a person willingly smuggled across state borders may find out, too late, that s/ he has in fact been trafficked. Indeed, law enforcement personnel admit that migrant smuggling and human trafficking are practically indistinguishable. ${ }^{106}$ Nevertheless, pursuant to the Migrant Smuggling Protocol,

102 See Gallagher, supra note 71.

103 U.N. Ad Hoc Committee on the Elaboration of a Convention Against Transnational Organized Crime, Protocol Against the Smuggling by Land, Sea and Air, supplementing the UN Convention Against Transnational Organized Crime, Annex III; UN Doc. A/55/383 (2000) [hereinafter the Migrant Smuggling Protocol)].

104 Id. at art. 3(a). Article 3(b) defines "illegal entry" to "mean crossing borders without complying with the necessary requirements for legal entry into the receiving state."

105 Compare Article 3(a) of the Trafficking Protocol with Article 3(a) of the Migrant Smuggling Protocol. See Trafficking Protocol, supra, note 88 at art. 3(a) and Migrant Smuggling Protocol, supra note 103 at art. 3(a).

106 See Andrew Cockburn, 21st Century Slaves, NAT'L GeograPhic, September 2003, at 9:

Almost invariably those who cannot migrate legally or pay fees up front to be smuggled across borders end up in the hands of trafficking mafias. "Alien smuggling [bringing in illegal aliens who then find paying jobs] and human trafficking [where people end up enslaved or sold by the traffickers] operate exactly the same way," said a veteran field agent from the U.S. Immigration and Naturalization Service (INS). "The only difference is what happens to people at the other end." 
states retain discretion to determine whether an individual victim consented or even contracted to be smuggled across the border or was a victim of trafficking. Dr. Gallagher pointed out that "[n]othing in either Protocol acknowledges [the] operational link between smuggling and trafficking."107 She further opined that

Implementation of the new distinction between trafficked persons and smuggled migrants is likely to be controversial. The failure of the protocol to provide guidance on the identification issue is a significant, and no doubt deliberate, weakness. The potential problems are as follows: Under the terms of the two protocols, dealing with trafficked persons will be more costly and impose a greater administrative burden on states than dealing with smuggled migrants. States therefore have an incentive to ratify one and not both protocols. For the same reasons, border authorities and immigration officials responsible for identifying and categorizing irregular migrants also have an incentive to identify such persons as being smuggled rather than as trafficked. ${ }^{108}$

At the same time that anti-trafficking efforts were coalescing on the international front, the United States Congress was studying the problem of trafficking and its international and domestic manifestations. The Trafficking Victims Protection Act of $2000^{109}$ was adopted a mere month before the UN Organized Crime Convention and Trafficking Protocol were opened for signature. ${ }^{110}$ Together, the international instruments and the U.S. legislation have been influential in the fight against and interpretation of trafficking. In addition to the obligations voluntarily undertaken by state parties under the Convention and Protocol, the series of State Department reports issued pursuant to the mandates of the TVPA have vastly increased public and institutional awareness of, and knowledge about, human trafficking. ${ }^{111}$ The assertion of political and economic pressure by the United States through its "naming and shaming" and "carrot and stick" tactics has encouraged numerous states to sign onto and ratify the Trafficking Protocol. ${ }^{112}$ In addition, the sanctions

\footnotetext{
107 See Gallagher, supra note 71, at 1001.

$108 I d$. at 1000 (emphasis in original).

109 See Trafficking Victims Protection Act of 2000, 22 U.S.C. $\$ 7101$ (2000).

110 The UN General Assembly adopted the Convention on November 15, 2000, opening it for member state signature. The Trafficking Victims Protection Act became law in the United States on October 28, 2000. See Statement on Signing the Victims of Trafficking and Violence Protection Act of 2000, 36 WeekLy Comp. Pres. Doc. 44, at 2662 (Oct. 28, 2000).

111 The U.S. State Department has issued Annual Reports in each of 2001 through 2007. Each successive Report reflects a deepening and broadening of the scope of coverage of the Reports.

112 States which do not meet the minimum standards outlined in the Trafficking Victims Protection Act face U.S. economic sanctions. See Trafficking Victims
} 
and "naming and shaming" aspects of the TVPA, together with the influence of U.S. foreign policy efforts, have stimulated both governmental and NGO efforts directed against trafficking throughout the world. ${ }^{113}$

The law enforcement framework also is apparent in other international instruments. For example, Article 7 of the Rome Statute of the International Criminal Court, effective July 1, 2002, defines "enslavement," "sexual slavery," "enforced prostitution," and "other forms of sexual violence of comparable activity" as crimes against humanity. ${ }^{114}$ The Statute defines "enslavement" as "the exercise of any and all of the powers attaching to the right of ownership over a person and includes the exercise of such power in the course of trafficking in persons, in particular women and children." 115 However, these particular crimes against humanity may be prosecuted before the International Criminal Court only "when committed as part of a widespread or systematic attack directed against any civilian population, with knowledge of that act."116

Protection Act of 2000,22 U.S.C. $\S 7101 \S 110$ (2000). It may be an unanticipated bonus for the proponents of increased transnational law enforcement that, in order to sign onto the Trafficking Protocol, states must also ratify the UN Organized Crime Convention, which includes more wide-ranging requirements that state parties criminalize specified types of activities (including those not related to trafficking) and participate in transnational cooperation against such activities. See Gallagher, supra note 71, at 978 ("States must ratify the convention before ratifying one or any of its protocols.").

113 See, e.g., Chuang, supra note 91 , at $489-90$ for a description of the paradoxical effects of the U.S. reporting and sanctions regime on governmental and NGO antitrafficking efforts:

Anecdotal evidence suggests that the specter of TIP sanctions causes some governments (of developing countries, in particular) to develop their antitrafficking programs based entirely on what they perceive to be the expectations of the TIP Office. Focused on fulfilling those externally imposed standards, those governments fail to conduct their own, context-specific assessment of the needs on the ground, and overlook or ignore the recommendations of local NGOs. The pressure to conform to U.S. expectations thus has tremendous potential to chill government participation in anti-trafficking norm development within their own countries, not to mention at the global level.

The [Trafficking Victims Protection Act] sanctions regime has also had a chilling effect on NGO participation in the TIP reporting process itself. While the TIP Office actively encourages NGOs to contribute data to the TIP Report, there have been reports of retaliation against cooperating NGOs by their host governments in response to poor rankings in the TIP Report.

(citations omitted).

114 See Rome Stat. of the Int'l Criminal Court art. 7, II 1(c) and (g), July 1, 2002, 2187 U.N.T.S. 3.

115 Id. at art. 7, II 2(c) (emphasis added).

116 See A. Yasmine Rassam, International Law and Contemporary Forms of Slavery: An Economic and Social Rights-Based Approach, 23 Penn. St. L. Rev. 809, 835 (2005) (citing Prosecutor v. Akayesu, Case No. ICTR-96-4-T, Judgment, II85 (Sept. 2, 1998)). 


\section{B. Human Rights}

The human rights perspective is second most influential in framing and interpreting the issue of trafficking and in focusing public opinion. Both the international and domestic U.S. instruments evidence a mix of law enforcement and human rights concerns. The human rights framework used to interpret and combat the modern traffic in human beings focuses on the human rights violations suffered by the victims of human trafficking. ${ }^{117}$ Proponents of that framework point to the violation of the prohibition against slavery embodied in numerous international instruments, ${ }^{118}$ particularly the status of the prohibition against slavery as a ius cogens norm as well as constituting a crime against humanity. ${ }^{119}$ In addition to violating the victims' human right not to be enslaved, trafficking in humans violates other rights, among them the rights to freedom of movement, to minimum labor conditions, to payment for labor, and to bodily integrity. ${ }^{120}$

117 However, at least one legal scholar has questioned the characterization of human trafficking as constituting violations of human rights, pointing to international law's recognition and enforcement of human rights against states, rather than private actors. See Ryszard Piotrowicz, Trafficking in Human Beings and their Human Rights in the Migration Context, in InTERnational Migration Law 275, 278 (Ryszard Cholewinski, et al, eds., 2007) (posing the question). While acknowledging the international human rights focus of various international instruments targeting trafficking, Professor Piotrowicz warns that characterization of trafficking as violative of victims' human rights obscures understanding of the traffic in human beings and may lead to failure of the efforts to provide victims with assistance and protection. Id. at 281 .

118 See, e.g., Rassam, supra note 116, at 809-810. The international instruments that embody the prohibition against slavery include the Slavery Convention of 1926 , Sept. 25, 1926, 46 Stat. 2183, U.S. No. 778, 60 L.N.T.S. 253; the 1956 Supplementary Convention on the Abolition of Slavery, the Slave Trade, and Institutions and Practices Similar to Slavery, entered into force Apr. 30, 1957, 266 U.N.T.S. 40; and the International Covenant on Civil and Political Rights, G.A. Res. 2200A (XXI), U.N. GAOR, 21st Sess., 999 U.N.T.S. 171 (opened for signature Dec. 16, 1966, entered into force Mar. 23, 1976).

119 Rassam, supra note 116, at 810 . Customary norms of international law which have attained the status of ius cogens are nonderogable. See Restatement (THIRD) of the Foreign Relations Law of the United States $\$ 702 \mathrm{cmt}$. $\mathrm{n}$ and Reporters Note 11 (1987). The list of ius cogens norms includes the prohibitions against slavery, piracy, and the use of force, for example. A norm's attainment of ius cogens status signifies the deep and broad consensus of the international community on the issue. Id.

120 The International Covenant on Civil and Political Rights, Dec. 16, 1966, 999 U.N.T.S. 171 [hereinafter ICCPR], prohibits slavery, servitude and forced or compulsory labor. See art. 8. The ICCPR also recognizes rights to freedom of movement (art. 12) and association (art. 22). Article 7 of the International Covenant on Economic, Social and Cultural Rights, Dec. 16, 1966, 993 U.N.T.S. 3 [hereinafter IESCR] recognizes rights to "just and favourable conditions" of work and fair wages, among other things. See id. at art. 7. 
The human rights framework focuses on the victim, requiring justice for violation of those rights that are legally recognized and protected but, more importantly, protection of those rights and, through them, the rights holder. ${ }^{121}$ While proponents of the human rights framework, as well as women's rights advocates, succeeded in the inclusion of victim protection provisions in the Trafficking Protocol, commentators note that the law enforcement provisions are clearly prioritized by that instrument. ${ }^{122}$ Although it may be argued that the law enforcement framework's mechanisms function to uphold and protect the human rights (including women's and children's and labor rights) violated by the traffic in human beings, a close reading of the Organized Crime Convention and Trafficking Protocol makes clear that the law enforcement concerns (criminalization, prosecution and border enforcement) were predominant. ${ }^{123}$ The Convention is, therefore, "essentially an instrument of international cooperation," 124 the central focus of which is to "combat transnational organized crime more effectively, rather than the protection of the victims of the crimes and/or their human rights." 125

Confronting clear evidence of member state law enforcement priorities, proponents of the human rights framework nevertheless continue to proffer other rights, the recognition and protection of which proponents claim would contribute to victim protection, and perhaps to a diminution in the incidence of trafficking, by stemming the supply of potential victims. ${ }^{126}$ Others place great emphasis on women's and children's rights, a

121 See, e.g., Bruch, supra note 86, at 32 ("A human rights approach centers on the individual affected and offers the possibility of reconceptualizing that person as a rights holder rather than a mere 'victim' .... One is entitled to protection of [human] rights simply by virtue of being human ...."). Professor Bruch offers an insightful assessment of the development, manifestations, benefits and disadvantages of the law enforcement, human rights, and women's rights frameworks. See id. passim. See also Rassam, supra note 116, at 851 ("situating the discourse on slavery within a human rights context enables a dual recognition of their victimization and their voice as holders of rights and participants in the discourse on slavery.").

122 See, e.g., Gallagher, supra note 71, at 989 ("Part Two of the protocol, dealing with protection of the trafficked person, contains very little in the way of hard obligation."). See also Chuang, supra note 91, at 448 ("To the extent the [Trafficking] Protocol obliges states parties to provide assistance and protection to trafficked persons, it is mostly couched in aspirational terms rather than as a matter of hard obligation.").

123 Gallagher, supra note 71 , at 976.

124 Id. at 978.

125 Id. Arguably, law enforcement, including law and order and border enforcement, is a necessary (if insufficient) precondition for the recognition and protection of human rights.

126 See, e.g., Jonathan Todres, The Importance of Realizing 'Other Rights' to Prevent Sex Trafficking, 12 Cardozo J. Gender \& L. 885 (2005/6) (advocating the recognition and protection of the rights "to be free from gender-based violence and discrimination; (2) the right to be free from other forms of discrimination; (3) the 
specific subset of human rights, and the violation of international instruments that enshrine the rights of those groups and establish state obligations addressing these groups' vulnerabilities.

\section{Women's and Children's Rights}

Women and children are the most typical and violated of the victims of trafficking, and the stories told about and profiles of trafficking victims shine spotlights on young village girls and women who are sold by families and/or tricked into enslavement. ${ }^{127}$ Viewed through the prism of women's and children's rights, trafficking in human beings violates the human rights of women and children that are enshrined in various international instruments. ${ }^{128}$ Pursuant to this conceptual framework, recognition and enforcement of the rights of these groups by the governments of sending and receiving states will lead to a diminution in trafficking. ${ }^{129}$ The reported rise in the trafficking of human beings, however, points to the shortcomings of existing international instruments ${ }^{130}$ and calls for the development of greater international consensus regarding the status of women and the adoption of additional, more focused, instruments to combat modern traffic.

The principal international instruments enshrining women's and children's rights include: the UN Convention on the Elimination of All Forms of Discrimination Against Women (CEDAW) ${ }^{131}$ and the Conven-

right to birth registration; (4) health rights; and (5) the right to education."). Id. at 885.

127 See, e.g., U.S. DeP'T of State, Trafficking in Persons Report at 6, 19 (2007) [hereinafter 2007 TIP Report] (describing the sale and prostitution of young girls in Cambodia and Burma by their parents and other adults); see also Tiefenbrun, supra note 63 , at $141-42$.

128 See, e.g., Special Rapporteur on Violence Against Women to the Commission on Human Rights, Integration of the Human Rights of Women and the Gender Perspective, UN Doc. E/CN. 4/2000/68 (February 29, 2000). See also, Tiefenbrun, supra note 63, at 111-112 (enumerating some rights violated by sex trafficking and listing the international instruments in which those rights are enshrined).

129 Available statistics all substantiate the perception that women and young girls constitute the vast majority of trafficking victims. See, e.g., 2006 GAO Report, supra note 67 , at 12 . Table 2 compares the victim profiles reported by the U.S. government, the ILO, the International Office of Migration (IOM) and the UN Office on Drugs and Crime (UNODC). The UNODC report that $77 \%$ and $33 \%$ of victims were female and children, respectively, constituted the lowest of the tabulated estimates of victimization of these two groups of victims.

130 Convention on the Elimination of all Forms of Discrimination Against Women, 1249 U.N.T.S. 13 (1979) [hereinafter CEDAW]. CEDAW, for example, offers inadequate protection. See, e.g., Chuang, supra note 13, at 78.

131 See id. The U.S. signed CEDAW in 1980 but has not yet ratified the instrument. 
tion on the Rights of the Child (CRC) ${ }^{132}$ and its Protocols. Each of these conventions has been adopted by more than $150 \mathrm{UN}$ member states. ${ }^{133}$ Proponents of the women's and children's framework point to Article 6 of CEDAW, which requires that state parties "take all appropriate measures, including legislation, to suppress all forms of traffic in women and exploitation of prostitution of women." 134 Such proponents believe that Articles 32 and 34 through 36 of the CRC are especially pertinent to the efforts to combat trafficking. Pursuant to Article 32 of the CRC, state parties "recognize the right of the child to be protected from economic exploitation and from performing any work that is likely to be hazardous or to interfere with the child's education, or to be harmful to the child's health or physical, mental, spiritual, moral, or social development."135 Pursuant to Article 34, the state parties "undertake to protect the child from all forms of sexual exploitation and sexual abuse."136 Article 34, pursuant to which state parties undertake to "take all appropriate national, bilateral and multilateral measures to prevent the abduction of, the sale of or traffic in children for any purpose or in any form"137 appears to be even more compelling. In addition, under Article 36, state parties undertake to "protect the child against all forms of exploitation prejudicial to any aspect of the child's welfare."138

Failure to uphold those rights leaves women and children vulnerable to the danger of trafficking. Unfortunately, however, the enforcement provisions of both CEDAW and CRC are weak. ${ }^{139}$ Both require that signatory states submit to the applicable bodies created by each Convention

132 Convention on the Rights of the Child, 1577 U.N.T.S. 3 (1989) [hereinafter $\mathrm{CRC}$. Two optional protocols to the CRC have been adopted, and each has been adopted by close to 100 signatory states. See http://www.ohchr.org/english/bodies/ ratification/11_b.htm for the list of signatories. The two protocols are the Optional Protocol to the CRC on the Involvement of Children in Armed Conflicts and the Optional Protocol to the CRC on the Sale of Children, Child Prostitution and Child Pornography, GA Res. 54/263 (May 25, 2000), UN Doc. A/54/49 (the Child Trafficking Protocol).

${ }^{133}$ A list of CEDAW signatories is available at http://www.un.org/womenwatch/ daw/cedaw/states.htm; and a list of CRC signatories is available at http://www.ohchr. org/english/bodies/ratification/11.htm.

134 See CEDAW, supra note 130, art. 6.

135 CRC, supra note 132 at art. 32.

136 Id. at art. 34.

137 Id. at art. 35.

$138 I d$. at art. 36.

139 See, e.g., J. Oloka-Onyango \& Sylvia Tamale, "The Personal is Political," or Why Women's Rights are Indeed Human Rights: An African Perspective on International Feminism, 17 HuM. RTs. Q. 691, 715 (1995):

CEDAW has the weakest implementation and enforcement mechanism of any human rights convention. It lacks a provision for individual petitions, the Committee charged with the supervision and implementation of the instrument is generally less well-endowed than any of its counterparts, and the number of 
reports on their domestic conditions. ${ }^{140}$ While these bodies may react to the substance of the reports, they have no authority to impose enforceable sanctions. ${ }^{141}$ The principal weapon available to try to effect concrete change is the shame that state parties may feel regarding publication of their failure to adhere to treaty obligations.

Advocates of a human rights approach that is centered in the protection of women and children have succeeded in making women and children a primary focus of international efforts to combat modern trafficking. The Trafficking Protocol is indicative of this focus: in its very title, it refers to its special interest in the protection of women and children, despite the realization that men, too, are also vulnerable to this type of exploitation. ${ }^{142}$ One consequence of this choice is the fostering of a gendered perception of the modern traffic in human beings. That perception, by dint of the status of women in many societies, may relegate human trafficking to a "women's issue," and fail to attract the resources of time, energy, and money that might be conferred if trafficking in humans were perceived as a broad societal problem. The focus on protection of women and their perceived "proper" role is exemplified by the battle over "consent" (whether a victim could ever consent to being trafficked or to engage in prostitution) in the negotiations leading to the drafting and adoption of the Trafficking Protocol. ${ }^{143}$ While purporting to

reservations to the Convention's substantive provisions are the highest of any international human rights instrument.

(citation omitted).

140 Pursuant to Article 22 of CEDAW, states parties undertake to submit national reports to the Secretary General of the UN for consideration by the Committee on the Elimination of Discrimination against Women. See supra note 130 at art. 17 and 22. Pursuant to Article 44 of the $\mathrm{CRC}$, states parties undertake to submit regular reports to the Committee on the Rights of the Child through the Secretary General of the United Nations. See CRC, supra note 132 at art. 43 and art. 44.

141 However, on October 6, 1999, the UN General Assembly adopted the Optional Protocol to the CEDAW. See G.A. Res. 54/4, U.N. Doc. A/RES/54/4 (Oct. 15, 1999). The Optional Protocol introduced new communications and inquiry procedures. See id. at art. 2 - art. 6 and art. 8. Pursuant to the new procedures, individuals and groups may make complaints against states who are signatories of the Optional Protocol to the Committee on the Elimination of Discrimination against Women and the Committee may institute inquiries into grave or systematic violations of CEDAW.

142 See, e.g., Peter Kiefer, Poles Seeking Jobs Found Forced Labor in Italy, N.Y. Times, July 23, 2006 (describing the enslavement in Italian labor camps of young Polish men who had responded to newspaper advertisements regarding job opportunities in Italy); and Cockburn, supra note 106, at 18 (describing the trafficking/smuggling and enslavement on Florida farms of Mexican migrant workers).

143 See, e.g., Chuang, supra note 91, at 443-44 (describing the conceptual debates during the negotiations leading to the Trafficking Protocol). As summarized by Professor Chuang, 
further the interests of women, such perceptions and policies may limit their ability to engage in autonomous decision making.

Women and children, due to their particular vulnerabilities, are the most sympathy-inducing victims of trafficking. As a result, anti-trafficking efforts have been concentrated on their plight. However, unless integrated into the broader human rights framework, placing the emphasis on the vulnerabilities of women and children runs the risk of relegating efforts against human trafficking to the backwaters to which women's human rights are often consigned in the international legal system. ${ }^{144}$ Another concern is that "protection" of women may lead to further restrictions of women's rights - an infantilization derived from the perceived need to "protect" women from potential threats much as one would protect a child. This danger is exemplified by some state responses reported by Linda Smith and Mohamed Mattar in 2004:

In response to the growing problem of trafficking in women for domestic service to the countries of the Middle East, a number of countries, both on the sending and on the receiving end, have undertaken certain preventive measures. For example, the government of Bangladesh, a country of origin for trafficking of women, in response to the increasing incidents of abuse of domestic servants in the countries of the Middle East, now prohibits single, unskilled females from traveling alone to most countries of the Middle East. In the Dominican Republic, the Directorate for Migration of the Dominican Republic has established certain rules for women traveling out of the country, which require them, for instance, to demonstrate to the Dominican authorities before leaving the country that they are in possession of at least $\$ 1,000 .{ }^{145}$

The perverse and counterproductive result of such legislation is to make women in those countries who wish to explore economic options

On one side of the divide are the "abolitionists," who believe that all prostitution is inherently exploitative and degrading to women. Abolitionists recognize no distinction between "forced" and "voluntary" prostitution and believe that the failure of states to prohibit all prostitution violates women's rights to sexual autonomy. On the other side are those who believe that women can choose sex work as a viable livelihood option because it is the absence of adequate protections for sex work - not the sex industry itself - that opens the door to trafficking and other abuses. Under this view, state action to penalize adults choosing to engage in prostitution amounts to a denial of individual liberty.

(citations omitted).

144 See, e.g., J. Oloka-Onyango \& Sylvia Tamale, supra note 139, at 694-95 ("The question [how indeed are women's rights human rights?] is not moot, given the continual marginalization of women and the 'ghettoization' of gender issues by the dominant structures of race, capitalism and patriarchy.").

145 See Linda Smith \& Mohamed Mattar, Creating International Consensus on Combating Trafficking in Persons: U.S. Policy, the Role of the UN, and Global Responses and Challenges, 28 FletChER F. WORLD AFF. 155, 165 (2004). 
abroad even more dependent on third parties (usually male) to facilitate their movement.

\section{Labor Rights}

Proponents of a labor rights framework in the fight against trafficking target a perhaps broader aspect of the phenomenon by focusing on the exploitation of the forced labor of the trafficking victim, rather than on the exploitation of their sexuality. This framework highlights the violation of internationally recognized and enforceable labor rights and also draws attention to migrant and would-be migrant laborers as a key source of trafficking victims.

One proponent calls for "a nuanced framework that understands how migration impacts trafficking." 146 Underlying this view is the principle that concentrating too much on the sexual exploitation of trafficking victims creates a failure to appreciate, identify, and combat situations that foster victim vulnerability. Victims of trafficking who are not also sexually exploited fall through the cracks with respect to the relief offered. On the international level, asserting that "the majority of trafficked persons are migrant workers," 147 commentator Anna Zalewski calls for a fuller integration of the law enforcement provisions of the Trafficking Protocol with the protections offered by the International Convention on the Protection of the Rights of Migrant Workers and Members of their Families (the "Migrant Convention"). ${ }^{148}$ According to Zalewski, the "wide range of economic, social, cultural and labor rights" offered by the Migrant Convention, including to undocumented workers, and the obligations undertaken by state parties to protect migrant workers and their families offer a bulwark against the exploitation of trafficking. ${ }^{149}$ In the domestic U.S. context, Professor Jennifer Chacón identified U.S. immigration and labor laws as intricately involved in creating preconditions that facilitate trafficking into the United States. ${ }^{150}$

Other strands of the labor rights framework seek to combat modern human trafficking through encouragement of governments to recognize and uphold the labor standards overseen by the International Labor Office. ${ }^{151}$ Enforcement of basic labor rights, including payment of a fair

146 See Zalewski, supra note 87, at 134 .

147 Id. at 121.

148 G.A. Res. 45/158, U.N. Doc. A/RES/ 45/158 (Dec. 18, 1990). (The Migrant Convention became effective on July 1, 2003.). See Zalewski, supra note 87, passim.

149 See Zalewski, supra note 87, at 127-128.

150 See Jennifer Chacón, Misery and Myopia: Understanding the Failures of U.S. Efforts to Stop Human Trafficking, 74 FordHAM L. Rev. 2977 (2006).

151 The principal UN agency specializing in the setting and monitoring of labor standards, the International Labour Organization (ILO) was first created under the Treaty of Versailles. The organization monitors states' compliance with the international labor standards they have agreed to adhere to through, among other 
wage for labor, humane labor conditions, etc., would attack the conditions under which agricultural and factory workers labor in many countries. A number of ILO instruments are believed to be particularly applicable to the labor rights framework. States that ratify the Convention (ILO No. 182) concerning the Prohibition and Immediate Action for the Elimination of the Worst Forms of Child Labor undertake to prohibit and eliminate slavery and practices similar to slavery, child use and procurement for prostitution and pornography, and child use, procurement and offering for illicit activities (specifically including drug trafficking), each of which is included among the Convention's list of the worst forms of child labor. ${ }^{152}$ In addition, as Professor Stephanie Farrior has noted, the identification of child prostitution as "one of the worst forms of forced labor" by the ILO's Committee of Experts on the Application of Conventions and Recommendations has led the ILO to focus its enforcement efforts on the trafficking of children. ${ }^{153}$ The 1930 Forced Labour Convention" ${ }^{154}$ defines forced labor as "all work or service which is exacted from any person under the menace of any penalty and for which the said person has not offered himself voluntarily."155 The 1957 ILO Convention Concerning the Abolition of Forced Labour ${ }^{156}$ retains the 1930 Forced Labour Convention's definition of forced labor ${ }^{157}$ and requires that state parties pursue "effective measures to secure the immediate and complete abolition of forced and compulsory labor." ${ }^{158}$ Other potentially relevant ILO Conventions include the Convention (ILO No. 87) On Freedom of Association and Protection of the Right to Organize $^{159}$ and Convention (ILO No. 95) on Protection of Wages. ${ }^{160}$

mechanisms, review of states' reports of their domestic conditions and visits to noncompliant countries. See Stephanie Farrior, supra note 13, at 223-225.

152 See Convention (ILO No. 182) Concerning the Prohibition and Immediate Action for the Elimination of the Worst Forms of Child Labour, art. 3, June 17, 1999, 38 I.L.M. 1207 (1999), entered into force Nov. 19, 2000.

153 See Farrior, supra note 13, at 223.

154 Convention (ILO No. 29) Concerning Forced or Compulsory Labour art. 2(1), June 28, 1930, 39 U.N.T.S. 55.

155 Id. at art. 2. See Rassam, supra note 116, at 837 and Michelle O.P. Dunbar, The Past, Present, and Future of International Trafficking in Women for Prostitution, 8 BUFF. WOMEN's L. J. 103, 113-114 (1999-2000) (discussing ILO instruments applicable to efforts against trafficking). See also Farrior, supra note 13, at 223-24.

156 Convention (ILO No. 105) Concerning the Abolition of Forced Labour, June 25, 1957, 320 U.N.T.S. 291.

157 Id. at art. 1.

158 Id. at art. 2.

159 Convention (ILO No. 87) On Freedom of Association and Protection of the Right to Organize, adopted by the General Counsel Sept. 7, 1948, 68 U.N.T.S. 17.

160 Convention (ILO No. 95) on Protection of Wages, January 7, 1949, entered into force September 24, 1952 (partially revised by ILO Convention No. 173) available at http://www1.umn.edu/humanrts/instree/ilo95.html. 
Ignoring or failing to appreciate the plight of non-stereotypical victims of trafficking ${ }^{161}$ allows loopholes and lacunae for such victimization to flourish. ${ }^{162}$ As noted by Teresa Loar in her testimony before the House International Relations Committee Subcommittee on International Relations and Human Rights:

Traffickers themselves are often engaged in more than one kind of trafficking because they follow the profits. For example, we see cases where girls are lured from a village and the traffickers force some of the girls to work in domestic servitude or carpet weaving, while others, considered more attractive, are culled out and sold to brothels. Thus, in the fight against trafficking, there are practical reasons why the United States does not limit its efforts to one form of trafficking over another form. ${ }^{163}$

\section{E. Another Voice: Market-Based Organizational Analysis}

Another conceptual framework offered in response to modern trafficking in human beings is an analysis of the business and organizational practices and purposes of traffickers. Unlike the four frameworks described above, at present this analytical framework does not appear to have been incorporated into any legal system.

Professor Louise Shelley offers a market-based business organization analysis of the traffic in humans which reflects the diversity of cultural and political contexts of the relevant markets and their participants. ${ }^{164}$ She discerns six different types of business models in the sex trafficking industry. Under the first model, the Natural Resource Model: Post-Soviet Organized Crime, women are a natural resource to be exploited in the same way that more conventional natural resources such as timber or minerals are exploited for economic gain. ${ }^{165}$ Pursuant to Professor Shelley's second model, the Trade and Development Model: Chinese Traffickers, while the market is more typically focused on the smuggling of men, the trade also covers the trafficking of women for sex. The model is characterized by the maintenance of longer-term relationships and trafficker

161 I.e., those not trafficked for sex (such as those exploited as domestic, factory or agricultural workers), and those who are adult males.

162 See Srikantiah, supra note 79, at 158 ("suggest[ing] that federal agencies implementing the statute have restricted relief based on a flawed understanding of victim volition, under which victims who appear to be under the total control of a trafficker are viewed as worthy of relief, and other victims are rejected as undeserving").

163 See Theresa Loar, Director, President's Interagency Council on Women and Senior Coordinator for International Women's Issues U.S. Dept. of State, Prepared Testimony for Fed. News Serv. (Sept. 14, 1999) (emphasis added).

164 See Shelley, supra note 77. Shelley's analysis is confined, however, to the sex trafficking industry.

165 Id. at 123 . 
concerns for long-term profitability. ${ }^{166}$ The profitability of the third model, the Supermarket Model: Low Cost and High Volume U.S.-Mexican Trade, is dependent on the movement of large numbers of people across the border at low cost. ${ }^{167}$ The fourth model identified by Professor Shelley, the Violent Entrepreneur Model: Balkan Crime Groups, is characterized by high rates of violence and human rights abuses directed toward the victims, victims' families, and investigators. ${ }^{168}$ Professor Shelley describes her fifth model, the Traditional Slavery with Modern Technology: Trafficking out of Nigeria and West Africa, as reliant on the exploitation of uneducated women and of children, noting that it resembles traditional slavery "modernized for the global age." 169 Finally, under the sixth model, the Rational Actor Model: Dutch Approach to Regulation, more than is the case with any of the other models (each of which involved varying degrees of usually disguised state complicity), the business of trafficking is regulated in a manner that is similar to the regulation of legitimate businesses. ${ }^{170}$ A characteristic of all six models identified by Professor Shelley is that vulnerable individuals are exploited by traffickers from their own countries and ethnic groups. The domestic traffickers first identify and procure the merchandise (victims) who are exploited for maximum profitability, according to the cultural, economic, and political norms of their home cultures. From these various home-grown sources, some of the merchandise may be traded to the global marketplace.

Professor Shelley's business organization framework comes closest, of the frameworks discussed in this Article, to an economic analysis of modern trafficking in human beings. Unlike the remediative frameworks discussed earlier, her framework both explicitly and implicitly refers to the economic incentives and entrepreneurial drives that form and facilitate the late 20 th and early 21 st century traffic in humans. ${ }^{171}$ The business organization framework does not fully analyze the ways in which the traffic in humans is integrated into the global economic structure. Nevertheless, given the availability of analyses such as hers, which parse the economic motivations and practices of traffickers, it is difficult to understand the slight emphasis of the other frameworks on prevention through economic mechanisms directed at the economic incentives of traffickers and would-be traffickers. ${ }^{172}$ Certainly criminals must be prosecuted, and

\footnotetext{
166 Id. at 124 .

$167 I d$. at 125 .

168 Id. at 126.

169 Id. at $126-27$.

170 Id. at 127.

171 Shelley does not really address (other than in her analysis of the Soviet natural resource model) why the traffickers choose this type of trade, other than the generic quest for profit.

172 The Trafficking Protocol does contain hortatory language regarding the need for economic stimulation of the economies of source countries. The Trafficking
} 
victims must be assisted and their rights vindicated. However, to fail to truly understand the causes and factors that generate the contemporary traffic in human beings is to be resigned to a never ending stream of imprisonment (of traffickers) and rights violation, vindication, and rehabilitation (of victims). Structural analysis of modern trafficking in human beings and understanding of intertwined factors, together with a multipronged approach, will lead to a more successful attack.

Of the conceptual frameworks analyzed in this Article, only Professor Shelley's seeks to identify the motivations and mores of the traffickers. Each of the other frameworks addresses the violated rights of the victim and if, like the law enforcement framework, it addresses the trafficker, it is in order to impose after-the-fact punishment which, it is hoped, will also serve to deter future acts of exploitation.

\section{F. Neo-Abolitionism}

The four dominant conceptual and legal frameworks for comprehending and combating the modern traffic, i.e., law enforcement, human rights, women's and children's rights and labor rights, are fundamentally neo-abolitionist, targeting, in the case of the United States, not only the traffic in humans, but the sale of sex. ${ }^{173}$ Neo-abolitionist thinking manifests a deep-seated conviction that this vastly complex and intricately networked economic, social, and political issue will be eradicated or controlled through legal mechanisms that focus almost exclusively on prohibition and punishment of the trafficker and rehabilitation of the violated victims. Since the rehabilitation needs of the victims are acknowledged, this is certainly not the bare-bones abolitionist approach that saw the end to legal trans-Atlantic slavery in Britain and its colonial possessions and in the United States. However, in light of the ongoing political,

Victims Protection Act contains similar provisions. However, the principal focus of both instruments is on criminalization and law enforcement.

173 See, e.g., Paula Goode, Letter to the Editor, Prostitution's Brutality, N.Y. Times, Mar. 18, 2007, at 11 (writing as the Acting Dir. Of U.S. Office to Monitor and Combat Trafficking). See also Andreas \& NADElman., supra note 80, at 37 ("As in the earlier prohibitionist crusade against white slavery, an underlying agenda for some of the most influential state and nonstate actors today is the targeting of prostitution via the transnational angle of targeting trafficking."). Even the Trafficking Protocol, the instrument hailed as the first multilateral anti-trafficking treaty, is flawed and shows the compromise of states parties and interested NGOs the unenforceable exhortation of the recognition of some human rights of victims in return for stronger obligations to coordinate in the criminalization and eradication of the trans-border crimes of which trafficking is a subset. The law enforcement framework, in particular, although softened by some overtures toward and concessions to human rights (as evidenced by the victim protection provisions that decriminalize, for instance, the illegal border passage of the victim and exhort other protective mechanisms by state parties), reflects a neo-abolitionist approach. See Trafficking Protocol, supra note 88, Arts. 1, 6 and 7. 
social, and economic manifestations in the United States and former British colonies and possessions (the Caribbean, for example), of the failure to deal with other than the legal underpinnings of trans-Atlantic slavery the evident faith in neo-abolitionism is puzzling.

Neo-abolitionism is also reflected in the push from some state parties to abolish prostitution. As Dimitri Vlassis explained, a major sticking point during the negotiations leading to the Trafficking Protocol was whether all types of prostitution should be made illegal. That drive toward the elimination of all forms of prostitution is manifested in the rhetoric of some U.S. administration officials. ${ }^{174}$ The TVPA does attempt to address some of the economic vulnerability of the victims and to remove some of the economic incentives of the trafficker by, for example, providing the victim a private cause of action to recover the trafficker's ill-gotten gains. This mechanism contrasts nicely with the abolitionist era of the nineteenth century, where compensation was paid, in the British West Indies and elsewhere, to the slaver-trafficker for loss of property, not to the exploited ex-slave. To the extent that mechanisms such as those provided by the TVPA are utilized, some of the concerns regarding the abandonment of the victim to the system may be overcome.

However, abolitionism, on its own, does not succeed in ending institutionalized exploitation. ${ }^{175}$ That is, to the extent that legal instruments are not aimed at the structural underpinnings of and incentives for the activities of the actors involved, mere prohibition and criminalization of the activities will not and cannot transform exploitative relationships. As explained by A. Yasmine Rassam,

Not only does abolition of slavery fail to provide economic measures requisite to remedy the social injustice perpetrated on the enslaved, it fails to create the conditions of agency. The limited utility of abolitionism, which reinforces the victimization of slaves and fails to provide post-emancipatory alternatives, is evidenced in the emancipation movement in the United States. ${ }^{176}$

Therefore, as a result of the continued necessity of securing cheap labor and of the racial hierarchy that had sustained trans-Atlantic slavery, the much-vaunted and celebrated abolition of the slave trade and slavery in the British Empire was followed by the introduction of the indentured servitude of Chinese and Indian laborers in the Caribbean colonies of the

174 See Goode, supra note 173 (writing as the Acting Dir., Office to Monitor and Combat Trafficking in Persons).

175 See, e.g., ANDreas \& Nadelman, supra note 80 at 34 ("The creation of a global regime directed at the suppression of the white slave trade early in the twentieth century accomplished little toward its objectives.") (discussing the attempt to abolish prostitution via the international instruments created to combat the white slave trade).

176 Rassam, supra note 116 , at 850 . 
British Empire, ${ }^{177}$ the "blackbirding" of the inhabitants of the South Pacific to the Queensland colony of Australia, ${ }^{178}$ and the forced labor of native inhabitants in many of the newly colonized territories of the dismembered African continent. ${ }^{179}$ The necessity of that cheap labor is demonstrated by, for example, the definition of slavery in the Slavery Convention of 1926 which was expressly circumscribed so as to exclude the forced labor exacted by colonial powers from natives of their colonial possessions. Pursuant to the 1926 Convention, while states are required "to prevent compulsory or forced labor from developing into conditions analogous to slavery," at the same time, "forced labor may only be exacted for public purposes." roads, public buildings, and other infrastructure of many African colonies. Similarly, in the United States, the Civil War, the Emancipation Proclamation, and the Thirteenth Amendment were followed by the horrors of Jim Crow, the Ku Klux Klan, and widespread lynchings and exploitation of the descendants of African slaves. ${ }^{181}$

It is worth noting that some historians have linked the widespread fight against slavery in Britain in the 1800 s to the emergence of a new working class whose status and well-being were linked to a re-evaluation of

177 See Eric Williams, From Columbus to Castro: The History of the CARIBBEAN 347-60 (1984). As succinctly summarized by Williams, "the Caribbean, which had in the seventeenth century sought in the white indentured servant a substitute for the indigenous Amerindian, turned in the nineteenth to indentured Asians as a substitute for the African slave who had supplanted the white indentured servant." Id. at 351.

178 See discussion, note 271 infra. The practice of blackbirding involved the kidnapping of South Pacific Islanders and their transport to the sugar-producing regions of Queensland.

179 See Lowell J. Satre, Chocolate on Trial: Slavery, Politics \& The ETHics of Business 43 (2005):

All European powers in the nineteenth and early twentieth centuries sought regular and inexpensive labor for their colonies. ... The ending of slavery and the slave trade in the nineteenth century forced employers to look elsewhere for labor. Indentured labor was one alternative, leading to the transfer of millions of people throughout the world. .. . Natives were drafted by governments to build roads, haul goods, collect rubber, and mine gold . . . .

See also id. at 1-12 (describing eyewitness accounts of the enslavement of natives in Africa in 1904-1905); Miers, supra note 10, at 24.

180 See 1926 Slavery Convention, supra note 118, at art. 5; discussion, notes 281 . 283 and accompanying text infra regarding the effect of the "except" clause in the Thirteenth Amendment and its impact in re-enslaving blacks.

181 See McKee, supra note 14; Guyora Binder, The Slavery of Emancipation, 17 CARdozo L. Rev. 2063, 2101-03 (1996) (arguing that slavery persisted and still persists in the form of racial subordination after the passage of the Thirteenth Amendment). 
labor. ${ }^{182}$ In much the same way, the international and domestic U.S. antitrafficking campaigns of the 1990s and today invite critical inquiry regarding whether the neo-abolitionist approach is the most effective way to attempt to confront and vanquish this "new" form of human exploitation. These campaigns may, instead, represent the coming together of strange bedfellows - the law enforcement, border, and sovereignty protection interests with the moralistic, anti-prostitution voices that hearken back to the strands of the temperance movement that triumphed in the U.S. Prohibition and international white slavery fights. And, in that case, if trafficking and prostitution are conflated, can current anti-trafficking efforts truly understand and curtail the modern traffic in humans?

\section{Analysis of the White Slavery and Trans-Atlantic Slave Trade Analogies and Their Uses}

This Part of the Article reproduces examples of invocations and analogies to white slavery and the trans-Atlantic slave trade and analyzes trends in that usage. As demonstrated here, the analogy to the transAtlantic slave trade is pervasive in the anti-trafficking discourse but that use is superficial, counterproductive, and harmful.

The use of analogies is fundamental to human reasoning and analysis, allowing the analyst to compare new experiences to old, categorize the new, and decide how and whether to deal with the newly encountered experience. In his analysis of policymakers' decisions during the Vietnam War, Professor Yuen Foong Khong explained that

Analogies are cognitive devices that "help" decision-makers perform six diagnostic tasks central to political decision-making. Analogies (1) help define the nature of the situation confronting the policymaker, (2) help assess the stakes, and (3) provide prescriptions. They help evaluate alternative options by (4) predicting their

182 See Davis, Inhuman Bondage, supra note 25 , at 246-48. That is, to the extent that labor and laborers were disdained as a result of enslavement in the colonies, it would be more difficult for the working class to demand respect and fair pay from the owners of capital. On the other hand, for capitalism and economic growth to continue to be viable, the working class's consumer demand had to be encouraged and facilitated through pay rises and other benefits. Id. at 248 :

[B]y the late eighteenth century there was a pressing need felt by both skilled workers and employers to dignify and even ennoble wage labor, which for ages had been regarded with contempt. And what could better dignify and ennoble free labor, and even provide a sense of equality between the man who pays wages and the man who received them than a common crusade against chattel slavery?

In an early example of Professor Derrick Bell's interest convergence theory at work, the interests of the owners of capital and of labor in the metropole were aligned with the emancipation interests of black slaves in the colonies. See Derrick Bell, Brown v. Board of Ed. and the Interest-Convergence Dilemma, in THE DERRICK BELL. READER 35 (Richard Delgado \& Jean Stefancic eds., 2005). 
chances of success, (5) evaluating their moral rightness, and (6) warning about dangers associated with the options. ${ }^{183}$

However, Professor Khong noted that

Historians and political scientists who study how decision-makers "learn" from the past have observed that policymakers tend to rely on the analogies that come most readily to their minds, that they are impressed by superficial similarities, and that they seldom probe more deeply or widely in search of less obvious but perhaps more relevant analogues. ${ }^{184}$

Professor Khong further identified the interaction of the analyst's resort to superficially appropriate analogies with human cognitive processes. Among the cognitive processes that he highlighted were (a) the fact that policy makers use the frameworks that are most familiar to them, (b) the use of top-down processing, where the information received is compared to the framework already identified, so that information that confirms that applicability of the chosen analogy is noted and contrary information discarded or ignored, and (c) the perseverance of the chosen analogy, in defiance of contradictory information. ${ }^{185}$ In that regard, Professor Khong noted that "[W]hen analogies are used to define the situation and evaluate the options ...., they 'introduce choice propensities into an actor's decision-making': they predispose the actor toward certain policy options and turn him away from others."186

Further, with respect to analogies to historical events and trends, Professor Khong asserted that their power

[I]s in part a function of how deeply ingrained they have become in the official and public mindset. When their lessons become part of the unspoken and spoken lore, when there is only one consensual interpretation, their premises and their relevance become matters of dogma that few will see fit to question. At that point, analogies step beyond their role as heuristic devices for discovering facts and explanations and assume the role of explanations and facts themselves. ${ }^{187}$

He cautioned that

[D]ecisions-makers often use history badly more often than not . . invok[ing] inappropriate analogues that not only fail to illuminate the new situation but also mislead by emphasizing superficial and irrelevant parallels. Inasmuch as such analogies influence decisions,

\footnotetext{
183 KHONG, supra note 18, at 10.

184 Id. at 35 .

185 Id. at 36-39.

186 Id. at 21 (quoting Alexander George, The Causal Nexus Between Cognitive Beliefs and Decision-Making Behavior: The 'Operational Code' Belief System, in Psychological Models in International Politics 112 (Lawrence Falkowski ed.,

187 Id. at 262.
} 1979). 
they are deemed to be at least partially responsible for costly or failed policies. ${ }^{188}$

In the popular mind, the deeply ingrained image and interpretation of the trans-Atlantic slave trade is of a revolting, tragic, and never-to-berepeated error in human history. However, yet more deeply ingrained is the racial hierarchy and subordination that allowed and fostered the centuries-long trade. It is the enslavement of whiteness that, together with the threats to state borders and authority, precipitated coordinated international action by state entities against the modern traffic in humans. But it is the image of enslaved Africans that will arouse and harness visceral public outrage and support for anti-trafficking efforts. Yet, ironically, the racism that arose from the trans-Atlantic slave trade prevents users of the analogy from delving more deeply into the substantive meanings and similarities of the modern traffic and the trans-Atlantic slave trade.

The examples reproduced and analysis conducted below expose the inherent contradictions of the competing and complementary invocation of analogies to the trans-Atlantic slave trade and white slavery. While the trans-Atlantic slave trade analogy is used to invoke the image of enslaved blacks in order to inspire taking action against modern trafficking in humans, at the same time the subordination of blacks, blackness, and the colored "other" is viewed as more "natural" than the enslavement of whites and whiteness.

\section{A. The White Slavery Analogy}

A layer of irony and contradiction is exposed with the realization that, like the trans-Atlantic slave trade, white slavery was a product of labor imbalances (albeit with greater agency inhering in the white slaves of the late nineteenth and early twentieth century), ${ }^{189}$ yet the leaders of efforts to combat white slavery chose to focus, much as today's anti-trafficking champions, on the sexual enslavement of victimized females, rather than on structural economic and social causes.

While relatively fewer overt analogies are made in the anti-trafficking discourse to nineteenth and early twentieth century white slavery, the effect of white slavery is pervasive on the perceptions of and mechanisms used to fight modern human trafficking and is present in both explicit and implicit invocations of white slavery in diverse fora. Professor Elizabeth M. Bruch argued that " $[\mathrm{t}]$ he early emphasis on protecting white women now seems obviously racist and sexist. Yet that emphasis has continued to pervade the current discussions of, and policy towards, human trafficking." 190 Professor Bruch further noted that "[a]s a result of these

188 Id. at 12 (emphasis added).

189 See discussion supra Part II and infra Part V.

190 See Bruch, supra note 86, at 3. 
biases, the current approaches to human trafficking replicate many of the flaws of earlier approaches - namely, a focus on victimization, a fruitless cycle of debate on the role of prostitution, problematic definitional questions, and a process of decision making that excludes critical voices." ${ }^{191}$ Even more, the focus of the late nineteenth and early twentieth century activists on sex and the protection of women has continued to limit understanding of the fundamental similarities among the transAtlantic slave trade, white slavery, and contemporary trafficking in humans.

\section{Media Reports and Commentary}

Illustrative examples that contribute to public perception of the issue appear in the media. A 1998 New York Times exposé of modern trafficking reported that:

The international bazaar for women is hardly new, of course. Asians have been its basic commodity for decades. But economic hopelessness in the Slavic world has opened what experts call the most lucrative market of all to criminal gangs that have flourished since the fall of Communism: white women with little to sustain them but their dreams. Pimps, law enforcement officials and relief groups all agree that Ukrainian and Russian women are now the most valuable in the trade. $^{192}$

As reported in the article, an anti-trafficking expert explained that: "It's no secret that the highest prices now go for the white women .... They are the novelty item now. It used to be Nigerians and Asians at the top of the market. Now it is the Ukrainians."193

A 1997 report by Global Survival Network quotes Vladimir, a Russian trafficker, who explained: "The Japanese will take anything, as long as she has a passport and she is Russian. Whether she is fat or skinny does not concern them."194 The authors further noted that

Russian women are in high demand in many countries because of their "exotic" nature and relative novelty in the sex market. Russia and the Newly Independent States, including Ukraine and Latvia, have become primary "sender" countries, supplementing and some-

191 Id.

192 Michael Specter, Traffickers' New Cargo: Nä̈ve New Slavic Women, N.Y. Times, January 11, 1998 (emphasis added), reprinted in 146 Cong. Rec. 15, 22042-43 (2000).

193 Id. (quoting Marco Buffo of On the Road, an Italian anti-trafficking organization). That the perspective reflected in this New York Times article was influential in and reflective of the views of U.S. legislators perhaps may be inferred by the reproduction, in full, of the article in the Congressional record containing the discussions leading to adoption of the Trafficking Victims Protection Act.

194 Caldwell et al., supra note 85 , at 5. 
times replacing previously significant sources of women from Asia and Latin America. ${ }^{195}$

These descriptions of the customer demand forces at work in the markets serviced by the international sex trade may evidence both the objectification and sexualization of the exotic (and perhaps forbidden) and the ongoing reverberations of the racialized hierarchy of the nineteenth and early twentieth century migratory sex trade identified by Eileen Scully. ${ }^{196}$ The contemporary public, the pushers, and the customers share the same racialized perceptions of the "worth" of white human "merchandise" visà-vis non-white "merchandise." As the owners of African and Africandescended women created and exploited a hyper-sexualized erotic image of their slaves, so does the lingering desire to exploit and dominate "otherness" drive the valuation of the traffic's victims. ${ }^{197}$

The viewpoints and perceptions expressed can be analyzed on a number of levels: modern slavery is said not to be based on race, unlike the slavery of yesteryear. ${ }^{198}$ Yet the racism which arose with and permitted yesteryear's trans-Atlantic slavery makes today's enslaved white women more valuable vis-à-vis enslaved blacks or Asians. ${ }^{199}$ In addition, it was the specter of the enslavement of white women that most affronted public opinion in the West and spurred to action legislators in the West, who had ignored decades-long reports of the enslavement of Asian and African women and children. ${ }^{200}$ Added to the sense of urgency now surrounding

195 Id

196 See Scully, supra note 39, at 77 (identifying "the emergence of universal racialized sexual hierarchy"); discussion Part III.

197 See Chuang, supra note 13, at 69 ("racial factors can drive international trafficking across borders for the purpose of recruiting foreign women to meet the racial preferences of certain brothel clientele").

198 For example, according to John R. Miller, then-Director of the U.S. State Department's Office to Monitor and Combat Trafficking in Persons, "[w]e believe that when we look at victims of the world today - unlike the slavery of preceding centuries where the chief criterion was race - we look at the victims of all races, and sadly as many as $80 \%$ are of the female gender, and as many as one-third are children." John R. Miller, The Call for A 21st Century Abolitionist Movement, 1 Intercultural Hum. Rts. L. Rev. 37, 38 (2006) (citations omitted).

199 See Specter, supra notes 192-93 and accompanying text. The disparity in the perceived "value" of white women vis-a-vis non-white women is exemplified in the United States by the difference in the media coverage of kidnapped, abused, or murdered white and non-white women. See, e.g., Eugene Robinson, (White) Women We Love, Wash. Post, June 10, 2005, at A23; Media Under Fire on Missing Persons: Uneven Emphasis on Attractive White Girls, Women Criticized, MSNBC, June 15, 2005, http://www.msnbc.com/id/8233195/from?ET/; Have You Seen Her? When Black Women Disappear, the Silence Can Be Deafening, Essence Magazine, June 22, 2005, at 128.

200 See, e.g., MiERs, supra note 10; Specter, supra note 192. 
the issue, was the newly perceived vulnerability of national borders following the fall of the Soviet Union. ${ }^{201}$

\section{Academia}

In an example from the legal academy of invocation of white slavery, Professor Nora Demleitner argued in her 1994 article for recognition of "forced prostitution" as an international offense. ${ }^{202}$ Professor Demleitner traced the international fight against sex trafficking from the First Congress of the International Abolitionist Federation in $1876^{203}$ through various white slavery conventions of the early twentieth century and the work of several UN agencies, such as the Working Group on Slavery. ${ }^{204}$ Throughout the article, Professor Demleitner clearly identified modern trafficking in humans as an issue of forced sex ("forced prostitution") having more in common with white slavery than with black trans-Atlantic slavery. Indeed, although she noted that the tactics employed in the abolition fight against black slavery were utilized by white slavery crusaders ${ }^{205}$ and recognized some similarities in the economic underpinnings of the modern sex traffic and trans-Atlantic slavery, ${ }^{206}$ she focused on the sexual exploitation of trafficking victims and did not address the systemic similarities in the three phenomena. ${ }^{207}$ Professor Demleitner implicitly viewed the international instruments through which white slavery was fought as the natural predecessors of the international cooperation that she advocated, and rejected categorization of forced sex as "slavery" or a form of slavery, arguing instead for the more

\footnotetext{
201 See supra notes 71-73 and accompanying text.

202 Demleitner, supra note 77 passim.

203 Id. at 165.

204 Id. at 176.

205 Id. at 165 ("In many respects, their crusade against trafficking in women and forced prostitution resembled that against black slavery.")

206 Id. at 189 ("As was black slavery in the nineteenth century, forced prostitution is not only a human rights issue but also an economic phenomenon.")

207 For example, she asserted that: "Since technology has not yet advanced enough to replace women's sexual services, the demise of forced prostitution based on economic considerations is far from imminent. In this regard, forced prostitution differs from slavery which became outmoded with the onset of industrialization and automation." Id. at 190 (citations omitted). As discussed in Part V infra, slavery did not end and has not become outmoded, and modern forms of enslavement are not confined to forced prostitution.
} 
specific name of "forced prostitution" 208 in order to avoid, among other risks, conceptual confusion with black slavery. ${ }^{209}$

\section{Legislation}

In public debates leading to the passage of the TVPA, despite some acknowledgement of the existence of labor trafficking, some influential U.S. lawmakers seemed particularly concerned about the sexual enslavement of white women from Eastern Europe. For example, Senator Sam Brownback, reading from the New York Times exposé discussed in Part IV.A.1 infra, declaimed:

It happens every single day. Not just in Israel, which has deported nearly 1,500 Russian and Ukrainian women like Irina in the past three years. But throughout the world, where selling naïve and desperate young women into sexual bondage has become one of the fastest-growing criminal enterprises in the robust global economy. ${ }^{210}$

Senator Paul Wellstone expressed similar motivations for supporting the trafficking legislation:

My wife Sheila urged me to do something about this problem several years ago. Consequently, she and I spent time with women trafficked from the Ukraine to work in brothels in Western Europe and the United States. They told us after the breakup of the Soviet Union and the ascendancy of the mob, trafficking in women and girls became a booming industry that destroyed the lives of the youngest and most vulnerable in their home countries. ${ }^{211}$

208 Demleitner, supra note 77, at 194.

Slavery tends to be viewed in terms of nineteenth century black slavery rather than be deemed a more general and all-encompassing concept. The problem with labeling forced prostitution as "slavery" is one of rhetoric and linguistics. Individuals react to and interpret data and stimuli with regard to similar happenings in their past that provide meaning to new data. "Our interpretation of any sign is our psychological reaction to it, as determined by our past experience in similar situations, and by our present experience." Because our past experience with the word "slavery" has been shaped primarily by nineteenth-century black slavery, the word denotes "whatever meaning it has through belonging to a [...] group of events, which may be called its context." It is difficult for lay persons to conceive of forced prostitution in the same overall framework as slavery even if the individual elements of the term legally fit into the definition of slavery.

(quoting The Rhetoric of Western Thought (James L. Golden et al. eds.,1983) (citations omitted).

209 Demleitner, supra note 77 , at 194-196.

210146 Cong. Rec. 15, 22041-42 (2000) (statement of Sen. Brownback) (quoting Specter, supra note 192).

211 Id. at 22045. However, the trafficking cases cited by Wellstone included the enslavement of non-white women and children i.e., Thai, Albanian, Mexican, Russian, Chinese and Czech. Id. at 22045-46. 
Despite his emphasis on sex trafficking during debate on the Senate floor, Senator Wellstone did acknowledge that trafficking victims were exploited in "sweatshops and other types of forced labor" in addition to brothels. ${ }^{212}$ And, of the draft of the TVPA, Senator Brownback stated, "[t]his bill challenges the myriad forms of slavery including sex trafficking, temple prostitution, and debt bondage, among other forms." 213

Senator Wellstone also noted that:

[O]ver a 3-year period, hundreds of women from the Czech Republic who answered advertisements in Czech newspapers for modeling were ensnared in an illegal prostitution ring. ${ }^{214}$

The emphasis on sex and a thrust toward prohibiting paid sex work is exemplified by administration official, Paula Goode, then-Acting Director of the Office to Monitor and Combat Trafficking in Persons, in her letter responding to a New York Times editorial:

[Your editorial] about sex slavery, leaves the impression that force and rape are somehow separate from prostitution. This impression is wrong. Few activities are as brutal and damaging to people as prostitution. . . The demand for prostitution creates sex slaves today ... ${ }^{215}$

The conflation of prostitution, forced prostitution, and trafficking for the purposes of sexual exploitation detracts from and weakens the fight against human trafficking. Using the anti-trafficking discourse to attack prostitution (in all its forms, even where consensual) diminishes the resources targeted at forced prostitution and trafficking for the purposes of sexual exploitation. It also creates an image of trafficking as a phenomenon purely exploitative of the sexuality and bodies of women and children, hiding the systemic exploitation of which trafficking in humans is but one extreme example. This conflation and the focus on sex fail to address the power/subordination dynamic in relationships and exploitations of labor and the poor, as well as developing versus developed country imbalances that form the stabilizing matrix that facilitates the modern traffic in human beings.

\section{B. The Trans-Atlantic Slave Trade Analogy}

The analogies to the trans-Atlantic slave trade occur in many fora and are widespread in media reports, the scholarly literature, legislative history, and policy and other pronouncements from the U.S. executive. A critical analysis of the usage of the trans-Atlantic slave trade analogy exposes some persistent trends and a stronger appeal to emotions than to the intellect. They may be summarized as (1) the emotional exhortation

\footnotetext{
212 Id. at 22046.

213 Id. at 22044.

214 Id. at 22046.

215 Goode, supra note 173.
} 
to action, (2) the diminution of the horror of trans-Atlantic slavery, (3) the assumption of the mantle of righteousness, and (4) distancing of our (enlightened) time from theirs or "how far we've come." Running throughout is an inherently contradictory view of trans-Atlantic slavery: it is both (a) the ultimate in evil that never should have been, but is being repeated and (b) less noxious than the modern traffic in human beings (either because more persons are victimized or because human trafficking is happening today).

\section{Emotional Exhortation to Action}

Here, the modern exploitation is compared to the trans-Atlantic slave trade in order to stimulate the audience to action. Trans-Atlantic slavery is used as an emotional and historic touchstone - the blueprint against which this "new" traffic is measured. As a result of the immediate access to visceral imagery and emotions that this touchstone evokes, the more the new system of exploitation is said to resemble the trans-Atlantic slave trade, the more powerful is the analogy-user's call to action; and the more likely it is that the audience will support the mechanisms suggested by the analogy-user in the crusade against the modern traffic.

For example, in a speech to the UN General Assembly on September 23, 2003, President George W. Bush declared:

We must show new energy in fighting back an old evil. Nearly two centuries after the abolition of the transatlantic slave trade, and more than a century after slavery was officially ended in its last strongholds, the trade in human beings for any purpose must not be allowed to thrive in our time. ${ }^{216}$

Note the President's use of the trans-Atlantic slave trade analogy: he refers to the "ending" of the trans-Atlantic slave trade two centuries ago (the United States ended its slave trade in 1807); and to the "end" of slavery. ${ }^{217}$ But he glides over the reality that the United States' internal slavery and slave trade did not "end" until the Civil War and the Thirteenth Amendment. Also ignored is the question whether the conditions endured by the ex-slaves and their descendants (including peonage and Jim Crow laws and customs, as well as other limitations on their freedom and autonomy) might fit within the definitions now used to delineate "modern slavery." 18 The effect of the tone of this speech is to bathe the

216 George W. Bush, President, Address to the United Nations General Assembly in New York City (Sept. 23, 2003), available at http://www.whitehouse.gov/news/ releases/2003/09/20030923-4.html.

217 The "end" and "ending" of slavery and the slave trade are in quotations to refer to the viability of the argument that there was no such historic end to the practice(s).

218 See Binder, supra note 181, at 2064 (discussing the post-Emancipation United States and "the paradoxical possibility that the institution of slavery could persist without any individual being lawfully held as a slave"). See also, McKee, supra note 
United States in righteousness - it is the crusader against the modern scourge without acknowledgement of its historic complicity or its modern role in the traffic in humans.

In his New York Times video blog, journalist Nicholas Kristof invokes the image of the trans-Atlantic slave trade to illustrate the horrors of modern trafficking in Cambodia.

Audio Narration: To us slavery seems a remote part of history but it is not. . . . They had been sold into slavery by their parents or kidnapped by neighbors. The problem here isn't prostitution, as such, and the real problem isn't trafficking, it is slavery. Every year worldwide 700,000 people are ensnared by human trafficking across international borders. I found it stunning that [simultaneous depiction of black slaves with the following scrolling text: It seems almost certain that the modern slave trade is larger in absolute terms than the Atlantic slave trade in the 18th and 19th centuries] scholars estimate that the slavery trade today is probably larger than it was in the 18 th or 19 th centuries. At its worst the trafficking system takes innocent village girls and imprisons them in brothels to be raped repeatedly. The big difference from 19th century slavery frankly is that they are all dead by AIDS in their early 20's. And these kids are just as deserving to be saved by the international community as the whales or as the Brazilian rain forest. Now the talk about sex slavery may sound like hyperbole, but it is not. And the shame lies not with the girls but with our own failure to respond as firmly to slavery today as our ancestors did in the $1860 \mathrm{~s}^{219}$

The excerpt exemplifies the use of emotional exhortation to action. The image of the horror of trans-Atlantic slavery is invoked and the modern traffic in human beings is compared to it, including the implication that the modern traffic is worse than was trans-Atlantic slavery. However, as is typical of such comparisons, the nature of trans-Atlantic slavery or a more than superficial analysis of it are not assayed. ${ }^{220}$

\section{Diminution of the Horror of Trans-Atlantic Slavery}

Here, once again evoking the touchstone of trans-Atlantic slavery and taking for granted broad consensus in favor of rejecting and condemning its horrors - the analogy-user implicitly or explicitly diminishes the horror of that historic and reverberating system of exploitation. The purpose of the user is to magnify the modern traffic in humans, whether

\footnotetext{
14 , at 150 (describing some of the mechanisms through which the freedom of blacks was constrained in the American South after Emancipation).

219 Nicholas Kristof, Heartbreak and Hope: A Return to Cambodia, N.Y. Times VIDEO, Dec, 18, 2006 http://video.on.nytimes.com/?fr_story=A641d424dd4599388bcd ae902ca7f45f1be4b010 (author's transcription).

220 See, e.g., discussion infra Part IV.B.2.
} 
with respect to the extent of the human rights violations committed or the scope of the exploitation (usually the absolute number of victims or number of countries involved). That diminution also serves to stimulate both emotional reaction and action in the reader-listener. The message, in effect, is "as horrible as you know the trans-Atlantic slave trade and slavery to have been, an even greater horror is full-fledged in our time, in our country, in our lives."

Some examples follow:

There are more slaves alive today than all the people stolen from Africa in the time of the transatlantic slave trade. ${ }^{221}$

Two hundred million people are victims of contemporary forms of slavery. Most aren't prostitutes, of course, but children in sweatshops, domestic workers, migrants. During four centuries, 12 million people were believed to be involved in the slave trade between Africa and the New World. The 200 million - and many of course are women who are trafficked for sex - is a current figure. It's happening now, today. ${ }^{222}$

Contemporary forms of slavery include bonded labour, trafficking, the worst forms of child labour, forced marriage and the abuse of domestic migrant workers. These now involve many times the number of people the transatlantic slave trade ever involved. Although reliable statistics on contemporary slavery are hard to come by due to its illegal nature, Kevin Bales estimates that 27 million people are contemporary slaves (Bales, 1999). Some international NGOs have put the number as high as 200 million. ${ }^{223}$

Whatever the exact number is, it seems almost certain that the modern global slave trade is larger in absolute terms than the Atlantic slave trade in the eighteenth and nineteenth centuries was. ${ }^{224}$

In analyzing the examples above, several issues are worthy of note: In the comparison made by Bales, and repeated by van den Anker and Kapstein, several aspects are overlooked. First, in their use of the transAtlantic slave trade as a comparator, the authors imply that modern trafficking is worse than the quintessential and readily accessible image of slavery. Second, the use of absolute versus proportional numbers as comparators is problematic. ${ }^{225}$ A meaningful analysis would refer to the pro-

221 Bales, Disposable People, supra note 5, at 9.

222 Specter, supra note 192, at 11 (quoting Michael Platzer, the Vienna-based head of operations for the United Nations' Center for International Crime Prevention).

${ }^{223}$ Christien VAN DEN ANker, Contemporary Slavery, Global Justice and Globalization, in The Political Economy of New Slavery 15, 18 (Christien van den Anker ed., 2004) (emphasis added).

224 See Kapstein, supra note 5, at 105.

225 Ethan Kapstein, at least, appears to acknowledge this in passing. See id. ("Whatever the exact number is, it seems almost certain that the modern global slave 
portion of the existing human population that was enslaved at the time of the trans-Atlantic slave trade versus the proportion of the contemporary human population that is enslaved, or to the proportion of Africa's then population that was enslaved during the slave trade versus the proportion of post-Soviet European or Asian population now enslaved. Another worthwhile calculation would be a comparison of the individual countries' or regions' proportion of export earnings or economic activity represented by the trade in enslaved persons at the time of the trans-Atlantic slave trade and in the present. Third, van den Anker's and Kapstein's references to Bales' and NGO statistics evidence academic, NGO, and official struggles to understand the scope of the trafficking problem. Unable to definitively pin down the scope of the modern traffic in humans, they unquestioningly repeat numbers thrown out by prior authors until those numbers gain the aura of hard fact. ${ }^{226}$

\section{Assumption of the Mantle of Righteousness}

Here, the analogy-user assumes the mantle of righteousness by invoking images of her own or her country's past actions against and continued condemnation of trans-Atlantic slavery. The mantle of righteousness confers authority upon the individual spokesperson or country, and delays or prevents questioning of the mechanisms now proposed or employed by that individual or country against modern trafficking in human beings. After all, who would [and why] question the activities of a country or person with such an impeccable anti-slavery lineage and proven methods of combating the analogous scourge?

Some examples follow:

People of conscience have fought against the different manifestations of slavery for centuries. This anti-slavery legislation is in the tradition of William Wilberforce . . . who [was an] ardent abolitionist .... ${ }^{227}$

The right to be free from slavery and involuntary servitude is among [the inalienable rights recognized in the U.S. Constitution]. Acknowledging this fact, the United States outlawed slavery and involuntary servitude in 1865 , recognizing them as evil institutions that must be abolished. Current practices of sexual slavery and traf-

trade is larger in absolute terms than the Atlantic slave trade in the eighteenth and nineteenth century was.") (emphasis added). Id.

226 See 2006 GAO REPORT, supra note 67, discussing the challenges of gathering reliable statistics about modern trafficking in human beings.

227146 Cong. Rec. 15, 22044 (2000) (statement of Sen. Brownback) (invoking the famous British anti-slavery crusader and legislator on the Senate floor during debate preceding passage of the Trafficking Victims Protection Act, which had been bundled with the Violence Against Women Act, Justice for Victims of Terrorism Act and Aimee's Law). 
ficking of women and children are similarly abhorrent to the principles upon which the United States was founded. ${ }^{228}$

More than 140 years ago, the United States fought a devastating war to rid our country of slavery, and to prevent those who supported it from dividing the nation. Although we succeeded then in eliminating the state-sanctioned practice, human slavery has returned as a growing global threat to the lives and freedoms of millions of men, women, and children. ${ }^{229}$

Further questioning and a more intellectual inquiry reveal, however, that the analogy-user's affiliated country was, firstly, not so committed in its opposition to trans-Atlantic slavery and, secondly, that the abolitionist mechanisms then deployed (versions of which are now advocated) were not as successful as is implied. ${ }^{230}$ Also implicit, especially in light of the staunch historical and contemporary opposition to the practice, is denial of any complicity in or avoidance of the appearance of involvement in the re-emergence of enslavement and slavery. Another thread is the condemnation of (developing) countries that are identified as complicit in or not working hard enough against modern trafficking. If country $\mathrm{X}$, for example, the United States or the United Kingdom, defeated slavery so long ago, shed so much blood, and eliminated slavery so successfully, why hasn't country Y, for example, Ghana or Thailand, done the same ${ }^{231}$ This use also turns the tables so that the historically victimized, that is, African countries that were sources of trans-Atlantic slaves, become the contemporary victimizers.

Structural inequalities that may appear to be "natural" because they are historically ingrained or biologically or otherwise "inevitable" all are manifested in the modern traffic in humans: male versus female; rich versus poor; developed versus developing countries; white versus non-white; and the state and corporate interests versus the individual. Assumption

228 Trafficking Victims Protection Act, 22 U.S.C. $\$ 1701(\mathrm{~b})(22)$ (Purposes and Findings).

229 U.S. Dep't of State, Trafficking in persons Report (June 2004), at 6.

230 See discussion, supra Part III.F.

231 See Kempadoo, supra note 42, at xvii.

[T]he dominant international approach to trafficking primarily identifies foreignoriginating international gangs and "source" countries as the main culprits, criminals, and beneficiaries in the trafficking business. Given that the majority of "destination" countries are claimed to be Western, postindustrial countries, this creates an international divide around nationality and race .... The narrow lens of the state anti-trafficking approach and the skewed representation of migration are particularly evident for the United States. ... Thus, the first U.S. government report to document trafficking in the country identifies Mexican, African, and Middle Eastern families; Thai and Latin American men; Russian, East European, and Italian organized crime groups and syndicates; Asian, Mexican, and Nigerian smuggling rings; the Canadian "West Coast Players"; Chinese Triads; Hmong gangs, etc., as the primary agents who profit and benefit from trafficking .... 
of the mantle of righteousness serves to hide from the listener-reader (and perhaps from the analogy-user herself) the structural participation of "legitimate" enterprises and institutions in modern trafficking in humans. ${ }^{232}$

\section{Distancing Our (Enlightened) Time from Theirs or "How Far We've Come"}

In distancing our modern times from the centuries of the trans-Atlantic slave trade, the analogy-users assure the contemporary listener-reader of her own virtue and hide the ball so that the listener-reader cannot see the structural and systemic similarities in the two phenomena. So, unlike the average individual and consumer of the past, today's listener-reader believes that she is not complicit in or a beneficiary of the modern traffic in humans. In addition, because the modern traffic in humans is presented as an aberration in our enlightened times, the listener-reader thinks that she need not question the systemic framework of our society, economy, or political systems. By hiding the ball, by assuring us of our lack of complicity, the analogy-user makes it easier for us to accept the neo-abolitionist law enforcement framework as potentially the most effective and complete for ending the repellent modern trade. Deeper inquiry into the legal, economic, social, and political framework of our contemporary world seems to be unnecessary.

Some examples of this trend include:

We have to make sure that we get our language straight. There are a lot of euphemisms. I head up an office that is called the Office of Monitoring and Combating Trafficking in Persons. Trafficking in persons is the euphemism; what we are really talking about is the slave trade. Back in the nineteenth century, when people talked about slavery, they did not talk about slaves. They talked about field hands or house boys. It made it sound better. Today we talk about forced laborers or sometimes the phrase sex worker - as if one could describe it as a normal form of work .... it is important to call it by its real name: slavery. ${ }^{233}$

Just as the British government (after much prodding by its subjects) once used the Royal Navy to stamp out the problem, today's great

232 As Kamala Kempadoo states:

The crediting of trafficking to the foreign "Other" who is configured as a threat to Western societies and civilization, serves thus as a scare tactic to corral racist, nationalist sentiments and to obfuscate the interaction between the state, corporate capital, and underground sectors .... The few cases of corporate corruption and use of trafficked labor that have come to light - such as Walmart and Tyson Foods in the U.S. . . suggest that there are indeed multiple parties who benefit from criminal activities.

Id. at xix.

${ }^{233}$ Miller, supra note 198 , at $41-42$ (citations omitted). 
powers must bring their economic and military might to bear on this most crucial of undertakings. ${ }^{234}$

Yet, if societies and states now are so enlightened and knowledgeable how could this form of exploitation (slavery) "re-emerge?" The distancing from the ancestral wrongs facilitates glossing over or ignoring the fundamental similarities between the trans-Atlantic slave trade and the modern traffic in human beings. Those similarities might point to a fundamental problem with modern civilization's system of organizing itself. After all, as Ethan Kapstein cautions, "Just as the brutal facts of the Atlantic slave trade ultimately led to a reexamination of U.S. history ... so must growing awareness of the modern slave trade spark a recognition of the flaws in our contemporary economic and governmental arrangements." 235

5. Superficiality of the Uses Made of the Trans-Atlantic Slave Trade Analogy

The uses of the trans-Atlantic slave trade analogy focus on affronts to human dignity, the ius cogens violation status of slavery, and the efforts of developed countries to combat this modern manifestation of slavery. The integral connection of the modern traffic with the global economic system is substantially unexamined, while seemingly acknowledged in a token fashion. For example, then-Director of the U.S. State Department Office to Monitor and Combat Trafficking in Persons, Ambassador John Miller, acknowledged the economic underpinnings of the new emergence.

I will list a few of the causes of human trafficking. Poverty is a tremendous push factor, and when coupled with the attraction for a more materialistic society, a pull factor, it forms one of the major foundations for human trafficking. Greed is a second cause. We have all heard about organized crime. We now talk about the big sources of revenue for organized crime: the drug trade, the arms trade, the people trade. Greed coupled with the attitude in many cultures towards women, imposes a higher toll on sex trade. Greed generates many categories of slavery, such as domestic servitude, child soldiers, factory, and farm labor slavery. There are exotic forms of slavery - such as child camel jockey slavery - in many of these countries. The challenges that these kinds of slavery pose for all nations are threefold. First and foremost, there is the challenge to human rights and dignity. Second, there is the health challenge. When you deal with sex slavery, you are dealing with HIV/AIDS and sexually transmitted diseases. Finally, there is the challenge of national security and stability. This challenge affects the stability of

${ }^{234}$ Kapstein, supra note 5, at 104.

235 Id. at 103. 
many countries, especially in how the slave trade is connected to organized crime. ${ }^{236}$

Yet, the United States' efforts against the traffic in humans, while acknowledging the economic connections of the human trade and the global economy, choose to focus legislative mechanisms on criminalization and punishment, rather than on structural solutions. The failure to proffer structural solutions does not necessarily denote ignorance, on the part of policymakers, of the structural underpinnings. ${ }^{237}$ However, that apparent understanding of the universal economic moorings of the human trade has not given rise to a comprehensive or effective solution. Instead, a perhaps subconsciously directed decision to reject uncomfortable reality - a form of willful innocence - may be at play. As a consequence, the discourse and the weapons employed against the scourge are impoverished by the lack of widespread appreciation of the economic role of trafficking in the globalizing twenty-first century and a failure to confront that role head-on.

While allusions to trans-Atlantic slavery are used to frame the discourse on the subject of modern trafficking in human beings, it is the fight against white slavery, rather than the trans-Atlantic slave trade, to which the typical modern trafficking combatant owes her intellectual debts. In effect, users of the analogies talk the talk of the trans-Atlantic slave trade, but walk the walk of white slavery - frequent analogies are made to trans-Atlantic slavery, but the conceptual and legal frameworks created to react to modern human trafficking embody the neo-abolitionist focus on sex and the criminalization-law enforcement model of the fight against white slavery.

In a letter to the New York Times, reacting to planned regulation of prostitution in Tijuana, Mexico, Ambassador John Miller asserted:

In addition to being inherently harmful and dehumanizing, prostitution and related activities fuel the modern-day slavery known as sex trafficking. What other "profession" creates such abuse and devastation?

While some attempts to regulate prostitution may be well intentioned, we should not be focusing on regulation of prostitution, but rather on abolition of slavery.

Apologists for the trans-Atlantic slave trade of yesteryear advocated for better ventilation and mattresses on ships for slaves, but all the

${ }^{236}$ Miller, supra note 198, at 38 (citations omitted).

${ }^{237}$ For example, in discussing the reasons for the Trafficking Victims Protection Act on the Senate floor, Senator Wellstone noted that "[ $\mathrm{t}]$ he trafficking of human beings for forced prostitution and sweatshop labor ... is one of the greatest aspects of the globalization of the world economy." 146 Cong. Rec. 15, 22045 (2000). In the same speech, he further stated that "[p]rofit in the trade can be staggering. . . . Trafficking has become a major source of new income for criminal rings." Id. 
regulation in the world would not have changed the fact that people used as slaves deserved freedom. The children and women of today deserve freedom too. ${ }^{238}$

Ambassador Miller's letter verges on the conflation of enslavement with sexual exploitation. The "people" enslaved during the trans-Atlantic slave trade "deserved freedom." However, it is women and children by implication, the sexually exploited -who deserve freedom today. While Ambassador Miller evokes the image of the historic systematic enslavement of Africans and the contemporaneous societal rationalizations in support of the trade, his concern about modern trafficking is focused on the sexual exploitation of innocent and vulnerable women and children.

\section{The Analogies Offer Much More}

Both the white slavery and trans-Atlantic slave trade analogies have been misused. The analogy to white slavery evokes sexual exploitation of hapless and vulnerable females, while the analogy to trans-Atlantic slavery evokes emotions of horror, rejection, and denial, and taps into popular misperceptions of that enslavement - that it was an aberrational practice. The systemic attributes of the two phenomena are unexamined, despite the availability of critical scholarship that offers more fundamental understanding of both, situating them within the economic, social, and political realities of their times. ${ }^{239}$

The heritage of white slavery is more entrenched than is the heritage of the trans-Atlantic slave trade in the legal and conceptual frameworks constructed in response to the modern traffic. While the legal weaponry has been broadened so as not to overtly exclude victims of any race and to implicitly include the victims of both genders, ${ }^{240}$ the white slavery analogy's evocation of sexual exploitation has a persistent hold on the analyses of policymakers and scholars. This Article contends that the analogy to the trans-Atlantic slave trade, thoughtfully and substantively explored, may provide a richer understanding of the modern phenomenon and illuminate a potentially more effective path to its eradication. ${ }^{241}$ The Article

238 Miller, supra note 3 (discussing the planned regulation of prostitution in Tijuana, Mexico).

239 See, e.g., Scully, supra note 39; Kempadoo, supra note 42; and DAvIs, supra note 25 .

240 See, e.g., the gradual transition from the race and gender specific titles of the relevant international treaties (see, e.g., supra notes 52-57) to more inclusive terminology. The change in the titles of the instruments reflects the modern instruments' more encompassing identification of victims and offenses.

${ }^{241}$ In-depth exploration of white slavery, particularly its situation within the migratory movements of the Industrial era, also may illuminate valuable systemic linkages and characteristics of modern trafficking in human beings. That exploration is beyond the scope of this article. 
further argues that the focus on abolition and law as the weapons of choice must be widened to address structural economic realities.

\section{A Perpetual Institution? Exploring the Trans-Atlantic Slave Trade Analogy}

Slavery as a social and economic relationship has never ceased to exist during recorded history, but the form that it takes and its definition have evolved and changed. ${ }^{242}$

Separated from the trans-Atlantic slave trade by a more-than-centurylong span of years and seeming eons in human social, cultural, and legal development, modern human trafficking might appear to be an aberration, a dreadful glitch in the march of human progress. However, a comparison of modern trafficking in humans and the trans-Atlantic slave trade lays bare the fundamental similarities in their functioning, their economic roles, and their intricate intertwining in the economic systems of their times. The analysis conducted here focuses on the status of slavery under the law; the status of the enslaved victim; the economic structure of the trade; and the level of integration of the trade in the broader economy. This Article does not pretend to accomplish a complete analysis of the similarities and differences between the modern traffic in humans and the trans-Atlantic slave trade. Instead, in this Part, this Article points to the structural characteristics of the two forms of exploitation which remain unexamined because of the superficial use made, thus far, of the analogy to the trans-Atlantic slave trade.

\section{A. Defining Slavery}

Modern trafficking in human beings has been characterized, not uncontroversially, as modern slavery. ${ }^{243}$ The analysis conducted in this Article is not dependent on either a determination whether the modern traffic in human beings is slavery or on the creation or acceptance of a particular definition of slavery. ${ }^{244}$ In view of the continuing controversy about definitions, and in order to provide helpful background to prepare for the conduct of this Part's in-depth comparison of modern trafficking in humans and the trans-Atlantic slave trade, it is helpful to review some of the more influential definitions and conceptualizations of what is slavery.

${ }^{242}$ Kevin Bales \& Peter T. Robbins, "No One Shall Be Held in Slavery or Servitude:" A Critical Analysis of International Slavery Agreements and Concepts of Slavery, Hum. RTs. Rev., Jan.-March 2001 at 18.

243 See, e.g., Kristof, supra note 219.

244 See Davis, Slavery and Human Progress, supra note 37, at 8 ("The more we learn about slavery, the more difficulty we have defining it.") Id. Slavery has existed throughout human history, as evidenced, for example, by Orlando Patterson's typologies. See, Orlando Patterson, Slavery and Social Death: A Comparative Study (1982). 
This review also illuminates the gap between legal and real prohibitions against slavery and slavery-like exploitation such as peonage and involuntary servitude, as well as the mutations of forms of exploitation in systems of entrenched subordination. The review also demonstrates the hollowness of statements that claim or imply the achievement of the demise of "slavery."

An ancient institution, slavery has existed throughout cognizable human history, ${ }^{245}$ and the reports of its demise have been greatly exaggerated. Efforts to define "slavery" have given rise to a great deal of controversy, steeped, no doubt, in the deep emotional reactions evoked by the term and invocation of the exploitation it represents. As stated by Kevin Bales and Peter T. Robbins,

The process of defining slavery has caused controversy in two ways: first, there are arguments about which practices should be categorized as slavery and thus designated for elimination, and secondly, because definitions have often been accompanied by obligations on states to carry out particular actions, there has been confusion about how to best accomplish the eradication of different forms of slavery. ${ }^{246}$

The conventional image of slavery is of "chattel slavery," the ownership, recognized and enforced by the legal system, of one human being by another. Historian David Brion Davis asserted that "[t]raditional definitions of slavery have stressed that the slave's person is the chattel property of another man or woman, and thus subject to sale and other forms of transfer . .."247 The enslavement experienced by Africans, beginning with their procurement for the trans-Atlantic journey, fits within this definition. Legal historian Andrew Fede summarized the perception of slavery in pre-Civil War America: "George Stroud . . . captured this idea when he called 'the cardinal principle of slavery' the notion 'that the slave is to be regarded as a thing, - as an article of property, - a chattel personal.'"248

Modern scholars and activists, however, have sought to expand the scope of the definition so as to include under its umbrella other forms of human-to-human domination and subjugation. For example, Orlando

245 Bales \& Robbins, supra note 242, at 18.

246 Id. at 20. Particularly pertinent to this article's criticism of the neo-abolitionist frameworks deployed to combat the modern traffic, the authors further note that: "This last question has been especially problematic since the relevant conventions have treated slavery as an institution that can be outlawed, but its actual eradication requires social and economic remedies in addition to legal ones." Id. (emphasis added).

247 See Davis, Inhuman Bondage, supra note 25 , at 30.

248 Andrew Fede, People Without Rights 4 (1992) (citing George M. Stroud, A Sketch of the Laws Relating to Slavery (1856)). See also Dredd Scott v. Sandford, 60 U.S. (19 How.) 393 (1856) (holding that blacks were chattel). 
Patterson defined slavery as "the permanent, violent domination of natally alienated and greatly dishonored people."249 Patterson expanded on his definition by noting that "[p]erhaps the most distinctive attribute of the slave's powerlessness was that it always originated (or was conceived of as having originated) as a substitute for death, usually violent death." 250 According to him, "[w]hat was universal in the master-slave relationship was the strong sense of honor the experience of mastership generated, and conversely, the dishonoring of the slave condition."251

Kevin Bales and Peter T. Robbins offer the following, arguably narrower definition: "a state marked by the loss of free will where a person is forced through violence or the threat of violence to give up the ability to sell his or her own labor power."252 While Patterson's definition dwells on the psychological, emotional, and social subjugation and inferior status of the slave, Bales and Robbins concentrate on the economic exploitation of the enslaved and stress the role of control in the relationship. ${ }^{253}$ Bales's and Robbins' definition would encompass both the slavery to which victims of the trans-Atlantic slave trade were destined as well as the subjugation of modern trafficking victims. The question whether Patterson's definition would encompass both types of trafficking in human beings is explored in Part V.B.2.b. infra.

\section{International Law Definitions}

In addition to the definitions proffered by scholars, "slavery" is defined in a number of international instruments and United States statutes. Kevin Bales and Peter T. Robbins traced the evolution of the international prohibition against slavery, and the definitions employed in international documents. ${ }^{254}$ According to the authors, the League of Nations' Slavery, Forced Labor and Similar Institutions and Practices Convention of 1926 contains the most influential international law definition of slavery. That convention defines slavery as "the status or condition of a person over whom any or all of the powers attaching to the right of ownership are exercised." 255 After discussing the restatements of and amendments to that original definition offered in a number of other inter-

249 See Patterson, supra note 244, at 13. Patterson further elaborates on his definition, noting that "[s]lavery is one of the most extreme forms of the relation of domination, approaching the limits of total power from the viewpoint of the master, and of total powerlessness from the viewpoint of the slave." Id. at 1.

250 Id. at 5.

251 Id. at 11.

252 Bales \& Robbins supra note 242, at 32.

253 Id

254 Id.

255 See International Convention to Suppress the Slave Trade and Slavery art. 1, March 23, 1926, 46 Stat. 2183, 60 L.N.T.S. 253. 
national instruments, ${ }^{256}$ the authors assert that "[i]n spite of . . restatements or additions, the definition of slavery in the international legal context has not essentially been altered since 1926, although slavery has been repeatedly prohibited in numerous later international conventions."257

\section{U.S. Domestic Law Definitions}

While the Thirteenth Amendment to the U.S. Constitution and federal statutes prohibit slavery and involuntary servitude, ${ }^{258}$ as well as peonage ${ }^{259}$ slavery is not explicitly defined under U.S. law. However, case law involving peonage and involuntary servitude provide some guidance regarding the contours of slavery as conceptualized under U.S. law. With respect to involuntary servitude, for example, in U.S. v. Shackney, the U.S. Court of Appeals for the Second Circuit noted that

The term involuntary servitude . . . is substantially synonymous with slavery, though it may perhaps be regarded as slightly more comprehensive, and as embracing every thing under the name of servitude, though not denominated slavery, which gives to one person the control and ownership of the involuntary and compulsory services of another against his will and consent. ${ }^{260}$

The central concept addressed by the court's definition echoes Bales and Robbins' focus on the exploitation, via ownership and control, of the economic output of the individual.

With respect to peonage, similarly, in the Peonage Cases, the federal District court for the Middle District of Alabama distinguished slavery from peonage and concentrated on the economic relationship. The court opined that:

Peonage was not slavery, as it formerly existed in this country. The peon was not a slave. He was a freeman, with political as well as civil rights. He entered into the relation from choice, for a definite period,

256 Bales \& Robbins, supra note 242, at 21-25. The international instruments analyzed include the Report of the League of Nations Temporary Slavery Commission; the Universal Declaration of Human Rights; and the Supplementary Convention on the Abolition of Slavery, the Slave Trade and Institutions and Practices Similar to Slavery of 1956.

257 Id. at 25.

258 See note 267 infra. See 18 U.S.C. $\$ 1584$ : "Whoever knowingly and willfully holds to involuntary servitude or sells into any condition of involuntary servitude, any other person for any term, or brings within the U.S. any person so held, shall be fined under this title or imprisoned not more than 20 years, or both."

259 See 18 U.S.C. $\$ 1581(a)$. "Whoever holds or returns any person to a condition of peonage, or arrests any person with the intent of placing him in or returning him to a condition of peonage, shall be fined under this title or imprisoned not more than 20 years, or both."

260 U.S. v. Shackney, 333 F.2d 475 (2d Cir. 1964). 
as the result of mutual contract. The relation was not confined to any race. The child of a peon did not become a peon, and the father could not contract away the services of his minor child, except in rare cases. The peon, male or female, agreed with the master upon the nature of the service, the length of its duration, and compensation. .... If the peon wished to change masters or service, he could find a new employer who would advance enough to pay the peon's debts to his then master, and the peon would then become bound in the new employer's service. ... U. Under later laws, the party could not abandon the contract, except by mutual consent or "by some sufficient motive given by one party to another, such as having grievously injured him, or where the master kept the accounts in an ambiguous manner, so that the servant could not understand them."261

In 1988, addressing the issue of involuntary servitude and overturning the conviction of a couple accused of holding retarded farm workers in involuntary servitude, the U.S. Supreme Court rejected the inclusion of psychological coercion as an element in the prosecution of cases of involuntary servitude. The Court interpreted "involuntary servitude" pursuant to 18 U.S.C. 241 and 18 U.S.C. 1584 to mean "a condition of servitude in which the victim is forced to work for the defendant by the use of threat of physical restraint or physical injury, or by the use or threat of coercion through law or the legal process."262 The Court's holding excludes from prosecution actors who exploit their victims through psychological, rather than physical coercion. At the same time, by including the threat of the law and legal processes, the Court leaves unanswered the question of where, on the continuum of physical to psychological coercion, lies the threat of legal action. ${ }^{263}$

Slavery, involuntary servitude, and peonage, then, each include the common characteristics of the victim's loss of control of ownership of self. Such loss of control varies in degree: in slavery, the enslaved individual has no control or right to any aspects of her personhood. Nor may the enslaved individual assert rights and privileges against either the society in which she lives or the owners of her self. Involuntary servitude and peonage, while also varied with respect to the attributes of human personhood that are lost, lack the legally enforceable chattel ownership of "conventional" slavery and center on the economic exploitation of the individual, lack or inadequacy of compensation for labor and constricted ability to sell that labor in the open market.

\footnotetext{
261 The Peonage Cases, 123 F. 671, 673-74 (D.C. Ala. 1903)

262 See U.S. v. Kozminski, 487 U.S. 931, $952-53$ (1988).

263 Id. at 953-59 (Brennan, J., concurring).
} 


\section{B. Comparative Analysis of Trans-Atlantic Slavery and Modern Traffic in Humans}

Trans-Atlantic slavery and the modern traffic in humans can be compared and contrasted on several levels. Mapping out the characteristics that both underlie and distinguish the phenomena to determine the nature of the relationships between modern trafficking in human beings and the trans-Atlantic slave trade and using the context of the preceding review of definitions of slavery and other slavery-like forms of exploitation will facilitate assessment of whether modern trafficking in humans is sui generis, requiring completely new paradigms and responsive approaches. In this Part, legal, economic, and social-psychological aspects are examined, as are the roles of states and empires. Wide-ranging aspects of these multi-faceted phenomena are addressed here. As a result, the exploration is necessarily superficial, speculative and incomplete, inviting more in-depth exploration by scholars and policy makers.

The examination begins with the comparison proffered by well-known anti-slavery activist Kevin Bales, who has assayed the most thorough comparison encountered by the Author in researching the two subjects. ${ }^{264}$ In hearings before the U.S. Congress during debates leading to passage of the Trafficking Victims Protection Act, Bales summarized his comparison between old forms of slavery (including trans-Atlantic slavery) and the modern traffic in humans as follows:

Differences between Old and New Forms of Slavery ${ }^{265}$

\begin{tabular}{|l|l|}
\hline Old Forms of Slavery & New Forms of Slavery \\
\hline Legal ownership asserted & Legal ownership avoided \\
\hline High purchase cost & Very low purchase cost \\
\hline Low profits & Very high profits \\
\hline Shortage of potential slaves & Surplus of potential slaves \\
\hline Long-term relationship & Short-term relationship \\
\hline Slaves maintained & Slaves disposable \\
\hline Ethnic differences important & $\begin{array}{l}\text { Ethnic differences less } \\
\text { important }\end{array}$ \\
\hline
\end{tabular}

264 See, also Katyal, supra note 14 (conducting detailed comparison of the sexual exploitation of female slaves in the antebellum South and contemporary forced prostitution).

265 Bales, Disposable People, supra note 5, at 8-33, as reprinted in Slavery Throughout the World: Hearing Before the S. Comm. on Foreign Relations. 106th Cong. 27 (2000), available at http:/frwebgate.access.gpo.gov/cgi-bin/getdoc.cgi? dbname=106_senate_hearings\&docid=f:69751.pdf 
Bales's purpose, both in his testimony before the Congress and in his book, is to spur his listener-reader to action by emphasizing the horrors of the modern traffic by distinguishing it from prior forms of human enslavement. As demonstrated in the analysis conducted in this Article, in his comparison, Bales does not identify certain fundamental structural similarities that supersede, in their impact, those characteristics that may distinguish the two phenomena.

\section{Legal Status of Slavery}

In comparing the two systems of exploitation, no contrast appears to be as stark as the differences between the legal status of trans-Atlantic slavery versus the status of slavery or enslavement under contemporary laws. On the international level, slavery is prohibited, the injunction against its existence or enforcement having risen to the status of a peremptory norm of international law. ${ }^{266}$ On the domestic level, the Thirteenth Amendment to the U.S. Constitution prohibits slavery or involuntary servitude in the U.S. or any place subject to U.S. jurisdiction. ${ }^{267}$ However, a closer examination reveals a more nuanced reality than is apparent from a review of legal instruments prohibiting the institution and practice of slavery - the coexistence of institutionalized slavery-like exploitation with legal abolition.

\section{a. International}

Beginning in the nineteenth century, starting first with its own abolition of the slave trade in 1807 and intensifying with its abolition of the institution of slavery in $1834-38,{ }^{268}$ Britain, through a mesh of bilateral treaties, and its enforcement and interception actions on the high seas, sought to stamp out the trans-Atlantic slave trade and slavery on the international level. ${ }^{269}$ With the Brussels Act of 1890, which divided Africa and assigned its parts to the domination of European powers, Britain was able to multilateralize the prohibition against slavery. ${ }^{270}$

266 "It is now a well-established principle that the 'prohibitions against slavery and slavery related practices have achieved the level of customary international law and have attained "jus cogens" status." Bales \& Robbins supra note 242, at 19 (quoting M. Cherif Bassiouni, Enslavement as an International Crime, 23 N.Y.U. J. INT'L L. \& Pol. 445 (1991)). However, as discussed in Part V.A. supra, the definition of the term continues to be disputed, and its contours therefore murky.

267 U.S. Const. amend. XIII, $\S 1$. "Neither slavery nor involuntary servitude, except as a punishment for crime whereof the party shall have been duly convicted, shall exist within the United States, or any place subject to its jurisdiction." Id.

268 See supra notes 31 - 37 and accompanying text.

269 Miers, supra note 10, at 14-17 ("By the 1880s, Britain stood at the center of a great network of treaties against the export and import of slaves by sea. No other power had acquired such rights or shouldered such responsibilities.").

270 Id. at 20-23; Davis, Slavery and Human Progress, supra note 37, at 305. 
However, even from those early days of the international effort, the prohibition existed most strongly on paper, with a perceptible gap between the text and exhortations of the legal instruments and the realities on the ground. The existence of that gap was widespread and slavery continued to thrive in colonies held by Britain, as well as in colonies of its European rivals. ${ }^{271}$

The gap between legal status and reality on the international plane continued through the adoption of the international instruments specifically targeting slavery ${ }^{272}$ and of the foundational international human rights instruments which also specifically prohibited slavery: the Universal Declaration of Human Rights, the International Covenant on Economic Social and Cultural Rights, and the International Covenant on Civil and Political Rights. ${ }^{273}$ For example, Saudi Arabia did not end legal slavery until the early $1960 \mathrm{~s}^{274}$ Mauritania continues the practice of chattel slavery today. ${ }^{275}$

\section{b. Domestic (United States)}

The principal legal weapons available to combat slavery in the United States are the Thirteenth Amendment to the U.S. Constitution, the federal and state statutes enacted pursuant to the amendment, as well as common law tort claims. Examples of federal statutes contemporaneous with the passage of the Thirteenth Amendment include the 1866 Civil

271 For example, Suzanne Miers outlined the difficulties faced by the European colonizers in effectively stamping out slavery in lands where the practice was well entrenched and continued to be profitable. Miers, supra note 10, at 41-43. Indeed, unable to stamp out the practice in their African colonies, the European powers made a show of rescuing and releasing slaves, but then used them in forced labor projects justifying the practice as necessary for the building of the colonies' infrastructures. Id. at 47-48. See also Davis, Slavery and Human Progress, supra note 37, at 305. The tenaciousness and persistence of subjugation and enslavement is also demonstrated by the practice of "blackbirding," through which the Australian colony of Queensland utilized the labor of natives kidnapped from neighboring South Pacific islands. See A. Price Grenell, Island Continent 164 (Angus \& Rorbertson eds., 1972) ("North Queenslanders had successfully established a plantation system which, in spite of controls, reproduced certain aspects of slavery, particularly in the disgraceful 'blackbirding' of island natives.").

272 See supra discussion, Part V.A. For a thorough review of slavery under international law, see Renee Colette Redman, The League of Nations and the Right to Be Free from Enslavement: The First Human Right to Be Recognized as Customary International Law, 70 CHi.-KeNT L. Rev. 759 (1994).

273 See supra discussion of the human rights framework in Part III.B.

274 Miers, supra note 10, at 347-350 (describing events leading to the manumission of slaves in Saudi Arabia and the arrangements made to pay compensation to their owners). However, according to Miers, "[c]harges that slavery and an active slave trade still existed in Saudi Arabia continued into the 1980s." Id. at 350.

275 Bales, Disposable People, supra note 5, at 80-120. 
Rights Act ${ }^{276}$ and the 1867 Anti-Peonage Act. ${ }^{277}$ More contemporary statutes include, for example, the 1964 Civil Rights $\mathrm{Act}^{278}$ and the Fair Labor Standards Act. ${ }^{279}$ Examples of state anti-slavery legislation include state civil rights and labor statutes. Common law tort causes of action that may be deployed against slavery and enslavement include false imprisonment, intentional infliction of emotional distress, and fraudulent inducement. ${ }^{280}$

The powerful injunctions of the Thirteenth Amendment, however, were constrained in their effect by the Supreme Court's interpretations during the Reconstruction period. ${ }^{281}$ Further, the North's abandonment of the ex-enslaved to the whims of their ex-masters began all too soon after the first halcyon days of Reconstruction. ${ }^{282}$ In addition, the Thirteenth Amendment's exception for the forced labor of convicts was perverted and exploited to deepen post-Reconstruction exploitation and de facto slavery of Southern blacks. ${ }^{283}$

The continuing gap between legal proscription and reality on the ground is exemplified by the emergence of trafficking in human beings in the United States. The available legal instruments were inadequate to the task of prevention of the traffic and punishment of the perpetra-

27642 U.S.C. ch. $21 \S \S 1981,1981$ A (2000)

277 Act of March 2, 1867, ch. 187, $\S \S 1,4,14$ Stat. 546 (codified at 18 U.S.C. $\S 1581)$.

278 Act of July 2, 1964, Pub. L. No. 88-352, 78 Stat. 241 (codified at 42 U.S.C. ch. 21).

27929 U.S.C. ch. $8 \S \S 201-19$ (2000).

280 See Baher Azmy, Unshackling the Thirteenth Amendment: Modern Slavery and A Reconstructed Civil Rights Agenda, 71 Fordham L. Rev. 981, 1037-38 (2002) (discussing the "patchwork" nature and ineffectiveness of these bases of relief from the exploitation of slavery).

281 See id. at 1000 ("Separated by ten years, the two most famous Reconstructionera cases, the Slaughter-House Cases and the Civil Rights Cases operated as a judicial vise that squeezed the Thirteenth Amendment into a doctrinal sliver.") (citations omitted). See also Chacón, supra note 150, at 2994-5 (describing limitations placed on the power of the Thirteenth Amendment by judicial interpretations).

282 See Lawrence M. Friedman, A History of American Law 504 (2d ed. 1985) ("By $1875 \ldots$. . [t]he North lost interest in black welfare . . Blacks were relegated to a kind of peonage .... A tight network of law and practice was woven about rural blacks, who were desperately poor and largely illiterate."). See also Michael J. Klarman, From Jim Crow to Civil Rights: The Supreme Court and THE Struggle for Racial Equality 10-15 (2004) (describing the factors leading to the abandonment by the North of efforts to protect Southern blacks).

283 See Davis, Inhuman Bondage, supra note 25 , at 30 ("The 'except' clause allowed states in the post-Reconstruction South to send blacks to prison or 'prison farms' on trifling or trumped-up charges and to lease slavelike [sic] convict labor to large private farms and mines.") 
tors. $^{284}$ In addition, few options were available for the protection and assistance of trafficking victims. To respond to modern trafficking in humans, the TVPA was adopted in 2000 . The bill was referred to by one of its co-sponsors as "the largest anti-slavery bill that the United States has adopted since 1865 and the demise of slavery at the end of the Civil War."285 Seven years after its adoption, it is still too early to tell whether the TVPA will be effective. By the end of 2005 , only 95 trafficking cases had been prosecuted in the United States under the TVPA and there is yet no evidence that the legislation has slowed the flow of victims into either the United States or international markets. ${ }^{286}$

2. Status of the Slave

a. Legal

Another clear distinction between the two forms of exploitation may appear to rest on the recognition or non-recognition of individual legal personhood in the slave. However, the issue of a slave's legal personality is more complex than may at first appear. Under the system of chattel slavery for which the captured Africans were destined, the slave was chattel property. That chattel, similar to other live chattel, was transferable and inheritable, and a repository of value that could be leveraged, including through mortgages and other financial arrangements. ${ }^{287}$ In addition, under most United States slave society legal regimes, the status of "slave" was inherited from the mother, so that slave mothers conferred their status as enslaved individuals to their children. Some U.S. states went so far as to forbid or create hurdles to individual manumissions, thus limiting manumissions of their slave children by owner-fathers. ${ }^{288}$

284 One example was the gap left by the Supreme Court's refusal to include psychological coercion within the definition of involuntary servitude. See U.S. v. Kozminski, 487 U.S. 931(1988).

285 Senator Brownback, 146 Cong. Rec. S10164-02 at S10166 (October 11, 2000).

286 See 2006 Attorney General Report, supra note 66, at 15. In fiscal year 2005, of the 229 applications for the $T$ visas created by the Trafficking Victims Protection Act to allow legal temporary residence in the U.S. to trafficking victims, 112 were approved. See id. at 12.

287 See Davis, Inhuman Bondage, supra note 25, at 139.

288 See, e.g., Thomas R.R. Cobb, An Inquiry in The Law of Negro Slavery $\S 340$ (1858), reprinted in Paul Finkelman, The Law of Freedom and Bondage: A Casebook at 100 (1986) [hereinafter Finkelman, Freedom and Bondage] ("In every slaveholding State, however, restrictions, more or less stringent, have been placed upon the manumission of negro slaves, and conditions prescribed to regulate the exercise of this privilege by the master."); George M. STroud, A SKetch of the Laws Relating to Slavery in the Several States of the United States of America (2d ed. 1856) reprinted in Finkelman, Freedom and Bondage, at 104:

[I]n addition to the obstacle to emancipation which is created by the saving in favour of creditors, a very extraordinary one is opposed on behalf of the widows of deceased slave-holders. For where a widow is entitled by law to one-third of 
As a consequence of the similarity of the status of the human chattel of trans-Atlantic slavery to the other live chattel (i.e., livestock) of the time, it might seem logical to assume that the American slave lacked legal personhood. Such, however, was not the case. The "problem of slavery," the effect of the "paradox of trying to reduce a human being to salable chattel"289 is evident in the quasi-chattel status of black [trans-Atlantic] slaves. Throughout the trans-Atlantic trade, while themselves categorized, officially, as chattel, some slaves had the power to own property, including other slaves, to enter into contracts of purchase with their owners on their own behalf or on behalf of others, to contract themselves out for labor on a semi-independent basis, and to be held criminally liable for crimes committed. ${ }^{290}$

The essence of the slavery to which victims of the trans-Atlantic slave trade were bound included the legally recognized and enforced dominance by the owner, which included legally enforceable, and enforced, physical dominance. The trafficker-owners of the modern system of human trafficking do not have the privilege of that legal sanction for their ownership of today's victims. It might appear, therefore, that the trafficker's domination of her victim depends purely upon the illegal assertion of physical control and the threat of violence and even death. However, deeper analysis reveals that the trafficker's ownership and

her deceased husband's personal estate, unless he shall have left sufficient other personal estate after payment of his debts, to satisfy her claim of one-third, his slaves, though declared to be free by his last will, shall nevertheless not be free, but shall be held liable for the third to which the widow is entitled.

(emphasis in original). See also Paul Finkelman, An Imperfect Union: Slavery, Federalism AND COMiTy 5-6 (1981) (describing the 1859 refusal of the Mississippi High Court of Errors and Appeals to give legal effect in Mississippi to the manumission in Ohio by a Mississippi slave owner of his slave daughter).

289 Finkelman, Freedom and Bondage, supra note 288 at 35.

290 See, e.g., id. at 137 ("Some slaves lived on their own, apart from their masters, and hired out their own time or even opened shops, paying a portion of their earnings for this de facto freedom."). See also Mark V. Tushnet, The American Law of SLAVERY 1810 - 1860: CoNSIDERATIONS OF HUMANITY AND INTEREST 108-111 (1981) (discussing a North Carolina appellate court's reduction from murder to manslaughter of a slave's criminal conviction for killing his owner, during which the court notes, of the convicted slave's actions: "it was human infirmity to struggle; it was terror or resentment, the strongest of human passions, or both combined, which gave the struggle its fatal result ..."). Id. at 110. See also id. at 111-116 for further analysis regarding the imposition of criminal liability on slaves in the ante bellum South. While almost certainly not required by statute or case law, the discretionary recognition of such power in the slaves furthered the interests of the slave society. The slaves contracted with third parties as the agents of their masters, and masters could enforce such contracts on their own behalf against the third parties. Entering into and honoring contracts with slaves that would allow the slaves to purchase themselves and/or family members served the interests of masters by holding out to the slaves an incentive to work hard (to the ultimate benefit of their masters). 
domination rests on physical and psychological control that is buttressed by the (in)direct complicity of states whose legal systems perpetuate the dominance and control of the trafficker through, for example, the citizen versus non-citizen dichotomy, passport and immigrant control, and threats of deportation, as well as the "otherness" of the victims. ${ }^{291}$

In contrast to trans-Atlantic slavery, with the possible exception of Mauritania and some other countries, ${ }^{292}$ no legal system today recognizes and enforces chattel slavery. ${ }^{293}$ Instead, trafficking victims may have "full" legal personality under the laws of the jurisdictions where they are held. Indeed, both international and domestic U.S. instruments specifically aimed at combating trafficking include provisions which purport to confer additional legal protections upon trafficking victims. ${ }^{294}$ However, the trafficking victim moved across international borders may not have a legal personality that is equal to that of citizens or legal residents of that jurisdiction. While contemporary laws may prohibit de jure enslavement and slavery, current legal frameworks may facilitate the de facto slaverylike exploitation, including trafficking, of certain vulnerable groups and individuals. In the United States, for example, the legal personhood of immigrants, legal and illegal, has been steadily chipped away under immigration laws. As in trans-Atlantic slavery, the legal personhood of these individuals and groups is a fraction of the personhood of the citizen or permanent resident. ${ }^{295}$

291 See, e.g., Chacón, supra note 150 , at 3039-3040.

292 Davis, Inhuman Bondage, supra note 25 , at 330 ("[C]hattel slavery is still widespread in such Saharan nations as Niger, Mauritania, Chad and Sudan ...").

293 As discussed supra Part V.B. 1, the prohibition against slavery has acquired the status of a peremptory norm of international law.

294 See, e.g., Trafficking Protocol, supra note 88 at art. 6 (detailing protections that State Parties should provide to victims of trafficking); and art. 7 (providing that State Parties should consider the adoption of domestic legislation providing trafficking victims a right to remain, either temporarily or permanently, in the receiving State Party).

295 See, e.g., Amy Goodman, Immigrant Families Sold Out, Locked Up, AlterNet, February 28, 2007, http://www.alternet.org/story/48627 (reporting on indefinite detentions of immigrants, including children, pursuant to federal immigrant laws). See also Priscilla Huang, Which Babies are Real Americans, TomPaine.com (Feb. 20, 2007), http://www.tompaine.com/articles/2007/02/20/which_babies_are_real_ americans.php (discussing the question whether a baby born to undocumented immigrants is an American in the same way that a baby born to non-immigrant parents is, and the introduction, in the 2006 federal legislative sessions, of bills aimed at denying U.S. citizenship to children whose parents are neither U.S. citizens nor permanent residents). In that sense, the status of a mother may, as in trans-Atlantic slavery, be conferred on her children. Today, all children born in the United States are U.S. citizens, without regard to the citizenship status of the parent. Nonetheless, to the extent that the parent is restricted to legal quasi-personhood, the child experiences the disadvantages resulting from that status. This issue may be moot in the case of women trafficked for forced prostitution, as the practice of today's owner- 


\section{b. Social and Psychological}

For purposes of the comparison of the social status of the trans-Atlantic slave and the modern victim of trafficking, the aspects of the social sphere that will be examined are the public/private distinction and the physical and psychological aspects of trafficking. One might expect that the legal prohibitions against slavery in virtually every country in the world would lead to a marked distinction between the social aspects of modern trafficking versus trans-Atlantic slavery. At the very least, a cursory analysis would indicate that the private and public social experiences of slavery would be very dissimilar.

\section{i. Quasi-Personhood}

The quasi-personhood of the slave (discussed supra with respect to the legal sphere) is also manifest in the social sphere. Orlando Patterson's definition of slaves as "natally alienated and generally dishonored persons"296 speaks to the social and psychological deracination of the enslaved person. Not only is the natally alienated person deprived of his/ her original identity that was created in and supported by the community and society from which $\mathrm{s} / \mathrm{he}$ springs, $\mathrm{s} / \mathrm{he}$ is deprived of further interaction with that community and of the ability to create a similar status in the slave society in which $\mathrm{s} / \mathrm{he}$ now finds her/himself. The enslaved person is dishonored because his/her status is completely dependent on the status and whims of the owner. ${ }^{297}$

Patterson's definition, meant to apply to all kinds of slavery, is certainly apt with respect to the trans-Atlantic slave trade. Individual Africans brought as slaves across the Atlantic were severed involuntarily from their natal homes and communities. They and their descendants, deprived of contact with and knowledge of their origins, were alienated from those origins, their status resting solely upon such recognition and patterns as the slave society and their owners chose to give them. ${ }^{298}$ The slave, then,

trafficker, in contrast to slave owners in the past, is to discourage procreation by their slaves, either through the use of forced birth control methods, or forced abortion. See, e.g., Bales, Disposable People, supra note 5, at 15 ("Today no slaveholder wants to spend money supporting useless infants, so female slaves, especially those forced into prostitution, suffer violent, involuntary abortions.").

296 Patterson, supra note 244, at 13.

297 David Brion Davis writes of the bestialization of the slave and the slave society's analogization of slaves to domestic animals. See Davis, Slavery and Human Progress, supra note 37, at 13 (discussing analogy of slave to domestic animal and perceived need to domesticate the wild beasts (slaves)).

298 This rupture in the construction of identity was exemplified in the experiences of the Reverend Al Sharpton, a prominent civil rights activist and former U.S. presidential candidate. Due to the research conducted by journalists, Reverend Sharpton learned in 2007 that his great-grandfather had been owned by relatives of Senator Strom Thurmond, a strong supporter of segregation. Reverend Sharpton said 
possessed a quasi-personhood, since the slave's identity was constructed by a society from which s/he was always excluded, which conferred onto the slave an identity derivative from the identity of the slave's owner.

The same is true for the victims of modern trafficking in human beings. Like the victim of trans-Atlantic slavery in both the private sphere, vis-àvis his/her enslaver and others in private interactions, and the public sphere, vis-à-vis the public society which surrounds him/her, the victim of modern trafficking is deprived of full personhood. The modern victim is wrested, by fraud, misrepresentation or coercion, from his/her natal community. In order to assert and maintain domination over the victim, the trafficker then "seasons" the victim, much as Africans brought across the Atlantic were "seasoned" into accepting their captivity, and as the captivity and resignation of their descendants were safeguarded. A multi-step process of committing physical and psychological violence against the victim (a violence that is unchecked by the "public" norms of society), including the confiscation of the victim's passport and other identity papers, strips the victim of his/her prior identity, establishes the absolute power of the trafficker, and, through the process of de-humanization, establishes for the victim that $\mathrm{s} / \mathrm{h}$ is no longer a member of human society, with the rights and privileges such membership confers. ${ }^{299}$ Victims come to experience a form of Stockholm Syndrome, where they become dependent on the trafficker as the individual who supplies the basic needs of their existence and their sole "connection" to the outside world.

Despite the ability to travel more easily among different regions of the world, like the victim of trans-Atlantic slavery, the modern victim's natal alienation may also be physical: while the African brought across the Atlantic had little chance of returning to the natal homeland even if freed, the modern victim, even if physically allowed to or facilitated in returning to his/her homeland, remains alienated from his/her home culture. The nature of the imprisonment and experiences that $\mathrm{s} /$ he has been forced to endure may deprive such victim of any likelihood of re-integration into or truly becoming, again, a part of his/her natal society. ${ }^{300}$ In addition, the psychological natal alienation wrought through the dishonor may be permanent, even if the physical alienation has been overcome.

that the experience brought home to him the reality that his identity was constructed by a slave society, to the extent that the origins of his own name now made him uncomfortable. See Bob Herbert, Slavery Is Not Dead. It's Not Even Past, N.Y. Times, Mar. 1, 2007, at A19 ("It was the first time in my life that I thought about why my name is Sharpton,' he said. 'I mean this whole thing is as personal as why your name is what it is. You're named after someone who owned your greatgrandparents." ").

299 See Tiefenbrun, supra note 63, at 109-110 (describing the process by which a typical victim is enslaved and "broken in").

300 See, e.g., Kempadoo, supra note 42, at xv-xvi (describing the societal alienation of trafficked victims returned to their home countries). 
The slave's dishonor identified by Patterson might be expected to exist purely within the private realm of the personal relationship between the victim of trafficking and his/her victimizer. That is, in a modern society, where slavery is prohibited, and outside the norms of society, surely any dishonor experienced by the slave would exist only between the enslaved and his/her enslaver-exploiter (as well as, in the case of trafficking for sexual exploitation, "customers" who exploit the victim for sex). The dishonor of the trafficking victim should differ from the slavery of yesteryear because the victim's dishonor should exist only within the relationship; the dishonor is not (or should not be) recognized or enforced by the legal systems of host countries. In reality, however, despite the difference in the laws applicable to slavery and enslavement, the victim's dishonor may extend into the public sphere. For example, under the TVPA, the victim may be required to testify about her enslavement. ${ }^{301}$ That testimony in all likelihood will become public record. Similarly, victims who are repatriated to their home country return with the stigma of the exploitation they suffered. ${ }^{302}$

\section{ii. Temporality: Permanence/Impermanence}

Another aspect of the social sphere of the two phenomena where one might expect to discern a clear distinction is the permanence versus impermanence of the social status of the victims. In trans-Atlantic slavery, the legal recognition and enforcement of enslavement helped ensure the permanence and inheritability of the status of slavery. ${ }^{303}$ By contrast, in modern trafficking, the condition is impermanent. ${ }^{304}$ Once the victim

${ }^{301}$ In order to qualify for the $\mathrm{T}$ visas created by the Trafficking Victims Protection Act to benefit victims of "severe forms of trafficking" (as defined in the Trafficking Victims Protection Act), victims must cooperate with law enforcement, including testifying against their traffickers. Law enforcement's certification of that cooperation is a pre-requisite for receipt of the visa. See Trafficking Victims Protection Act, 22 U.S.C. $\$ 7101 \S \S 107(b)(1)(C)$ and (E) (2000).

302 See Kempadoo, supra note 42, at $\mathrm{xv}$ - xvi.

${ }^{303}$ Indeed, to the extent that the "badges and incidents" of slavery continue to constrain the lives of the slaves' descendants through the proxy of racial subordination, the power relationships emplaced through the trans-Atlantic slave trade are permanent.

${ }^{304}$ In discussing "modern trafficking," this article does not include the debt bondage which has been much publicized in the last few decades. In debt bondage as practiced in such countries as India and Pakistan, the debt of the parent may pass to the child, and/or the child and his/her labor may be given to "work off" the debt. While the modern trafficker often exercises power over the trafficking victim by convincing the victim that s/he must work off the debt acquired from the trafficker's expenditure of transport and administrative costs attendant to the victim's movement and recruitment, that debt is not meant to be inheritable. See, e.g., Tiefenbrun, supra note 63 , at 110 and 141-42 (discussing the "debt bondage" in which trafficked victims are held). In addition to charging victims for the cost of their recruitment, traffickers 
has been profitably exploited by his/her trafficker, s/he can be discarded, and may re-join society as a "free" person. (With the caveat, of course, that with respect to the death while enslaved of individual victims, the enslavement experience for that individual is always permanent.) As discussed infra with respect to the mechanics of supply, the modern trafficker has neither the need for nor interest in making his/her victim's status inheritable. In fact, the trafficker would prefer that the victim not procreate, as such reproductive activity may interfere with the profit-creating activity for which the victim was acquired. The distinction rests on the fact that, in modern trafficking, there is no desire for population replacement - the apparently inexhaustible supply of disposable people eliminates the slave owner's need to assure internally generated replacement of the product. Further, the inability to assure that the victim's offspring would inherit his/her status removes any incentive to allow the waste of the victim's time and energy in the non-economically profitable activity of procreation. However, the impermanence of the condition of enslavement may be accompanied by a more long-term stigmatization of surviving victims of modern human trafficking.

\section{iii. Enslaver's Status}

A further distinction between the trans-Atlantic slave trade and modern trafficking in humans in the social sphere is the social status of the slaveholder. In Patterson's definition the dishonor of the slave is in direct proportion to the honor and status of the slave holder. That is, in the slave society, the very fact of being a slave holder confers high status on the owner. Indeed, in several societies identified by Patterson, the ownership of slaves is based not on the economic benefits that might be conferred, but on the psychological and social benefits of status enhancement. In fact, according to Patterson, the costs of slave ownership might be contraindicated in some societies in light of the economic realities of that relationship. In such cases, slave ownership may be largely ceremonial or status-based, conferring little, if any, economic benefit. In trans-Atlantic slavery, not only was the status of the slave owner enhanced, but the ownership of slaves created benefits for the owner.

Surely, given the underground and illicit nature of contemporary slave ownership, the status of the modern trafficker would not reflect a similar enhancement of status. Here, again, a distinction must be recognized between the public and the private spheres. In the private relationship between the modern victim and his/her trafficker, the absolute power enjoyed by the trafficker over his victim surely confers psychological "benefits" similar to those enjoyed by owners of African slaves. Contrary

will further bind the victim by charging him/her for the costs of feeding and housing the victim. See also 2007 TIP REPORT, supra note 127, at 26 (describing a trafficking victim who "owed" her trafficker for her plane ticket and whose debt was increased by her trafficker each time that a client made complaints about her). 
to expectations, however, those benefits are not confined to the private realm. The economic benefits that the modern trafficker extracts from his/her victim allow that trafficker to acquire goods and services that may enhance the trafficker's status in the public sphere. There may be a danger of loss of such status or even the creation of a diminished social standing should the illicit source of such benefits be discovered. Nevertheless, the trafficker may enjoy both private and public benefits during the span of the relationship. In addition, even covert slave-ownership and domination may confer the psychological satisfaction diagnosed by Patterson in addition to the economic benefits derived from ownership.

\section{iv. Societies as Victims}

Finally, when comparing the social aspects of the two phenomena, we should consider their effects on the societies of the enslaved-victim and the enslaver-trafficker. In trans-Atlantic slavery, the societies from which the enslaved Africans were wrested suffered long-lasting harms stemming from the breakdown of social, familial, and cultural ties. That breakdown was enhanced by the permanence of the rupture of the enslaved from their homes. This characterization might appear to contrast with modern trafficking. That is, as a sub rosa illicit form of exploitation, trafficking might appear to be less systematic in its effect on the origin and destination societies than was trans-Atlantic slavery. Such, however, is not the case. It is not only the trafficked individual who suffers harm: the society from which $\mathrm{s} /$ he originates, including family members, friends, etc., also may be affected by the disappearance of the individuals. In addition, to the extent that a society may become a known or reliable source of victims, the losses may become widespread through the society, affecting societal ties, psychological well-being, economic activities, and other characteristics. Therefore, in this regard, trans-Atlantic slavery and the modern traffic in humans cannot be clearly distinguished on the basis of the personal harm (limitation of injury to the individual) versus cultural and social harm to the originating societies: in both modern trafficking in humans and the trans-Atlantic slave trade, social, cultural, and psychological harm are inflicted on originating countries.

With respect to receiving countries, in addition to the vast economic benefits derived from coerced labor, trans-Atlantic slavery may have damaged the development of the receiving countries by stunting economic and political development, and coarsening psychological and social interactions through the everyday cheapening of the value of human life. ${ }^{305}$ (Clearly, that type of harm may also occur in sending countries

305 For example, it is arguable that, despite the Thirteenth and Fourteenth Amendments, human rights recognition and enforcement in the United States remain stunted by the compromise that enshrined the slave trade and the institution of slavery in the U.S. Constitution. See U.S. Const. art. I, $\S 2$, cl. 3; art. I, $\S 9$, cl. 1; and art. IV, $\S 2$, cl. 3 . 
where significant numbers of people go away and many never are heard from again.) Similarly, today, destination countries are damaged by their status in the modern trafficking industry: they receive the benefits of cheap labor, and because of the hidden nature of the traffic, the effect on political and social development may be minimized. However, in the U.S., for example, the coarsening of the legal and political environment is apparent. $^{306}$

\section{c. Race/Ethnicity}

Trans-Atlantic slavery and the modern traffic in humans may be contrasted with respect to the roles of race and racial characteristics. While race was a defining characteristic in determining enslavement in the era of trans-Atlantic slavery, race is said to be less important in modern trafficking. ${ }^{307}$ Trans-Atlantic slavery was racial slavery, while modern trafficking may appear to be more purely economic slavery, with some elements of race mixed in for good measure. According to that perspective, in trans-Atlantic slavery, the race of the Africans was key in determining the status of an individual, ${ }^{308}$ while race is not determinative today. Is race therefore meaningless in modern trafficking? To the extent that trans-Atlantic slavery and the experiences of colonization have left their marks on the world, including in the cognitive processes of the descendants of enslavers and the enslaved, race and racial characteristics continue to play a role in determining who will be a victim, the "value" of the victim, and the type of enslavement to which that individual will be destined.

Trans-Atlantic slavery was race-based; the economic, social, and legal systems and the slaver wanted the slave to stand out for reasons of effective control. David Brion Davis notes that "[w]hile slaves in antiquity could usually be recognized by clothing, branding, collars, and other symbols, the millennia-long search for ways to identify 'natural slaves' would

306 For example, the primaries leading up to the 2008 U.S. Presidential election were characterized by a competition among the Republican candidates to appear most virulently anti-immigrant. See, e.g., Bob Herbert, Rambo and the GOP, N.Y. Times, Dec. 1, 2007 (describing a recent debate among Republican candidates). See, also, Maria Pabón López, The Place of the Undocumented Worker in the United States Legal System After Hoffman Plastic Compounds: An Assessment and Comparison with Argentina's Legal System, 15 IND. INT'L \& Comp. L. Rev. 301 (2004-2005) (discussing the lowered standards to which employers are held when employeeclaimants are undocumented immigrants).

307 See, e.g., Bales, Disposable PeOPle, supra note 5, at 10 ("In the new slavery race means little.").

${ }^{308}$ This was not the case with respect to contemporaneous institutions of slavery in other parts of the world. For example, in North Africa and other parts of the Moslem world, although there was a thriving trade in slaves from Africa, people from other ethnicities were also enslaved. See, e.g., Davis, Slavery and Human Progress, supra note 37 , at $47-48$. 
eventually be solved by the physical characteristics of sub-Saharan Africans." ${ }^{309}$ In contrast, in modern trafficking, the slaver controls the slave more effectively if the slave does not stand out from the rest of society. That is, to the extent that the enslavement of the modern trafficked victim is illicit, the trafficker would prefer that his/her victim not be conspicuous, bringing unwanted official attention to his trade and perhaps leading to its destruction.

The racialized hierarchy of contemporary global civilization reflected in modern societies, which are largely multi-ethnic and multiracial, allows the slaver to have it both ways. Today in multicultural societies, people of some races, including the descendants of enslaved Africans, fit in, yet do not fit in. They belong to yet are strangers to their societies, fitting in by standing out as subjugated and inferior. That is, the badges and incidents of slavery and inferiority continue to have power due to the use of skin color, ethnicity, and race (and memory) as signifiers. ${ }^{310}$ Traffickers are thus able to take advantage of both trends in their attempts to profit from, yet stay hidden within, that society and away from the law. The trafficker now has no need to specialize in any one racial grouping, although $\mathrm{s} / \mathrm{he}$ may do so. The trafficker may utilize equal opportunity principles in deciding the nature of his business. Since, in multicultural societies, all races interact and blend in, trafficking victims are less conspicuous both when they are racial minorities - racial minorities are, and are expected to be, subordinate, their public subordination evoking little comment - and as whites or members of the majority - who are not expected to be subordinated and may therefore be hidden in plain sight.

The result of this mutability in status is that slaves walk among us, but we do not "see" them. The inability to see the subjugation of those expected to be subjugated perhaps played a role in the delay in the international community's mobilization to combat modern trafficking. Instead, as discussed in Part IV, supra, that mobilization came with the recognition of threats to state borders and awareness of the exploitation of Eastern European women whose physical appearance and ethnicity signaled that they should belong to the dominant group.

309 Davis, InHUMAN Bondage, supra note 25, at 34.

310 See, e.g., Kwame Anthony Appiah, A Slow Emancipation, THE N.Y. TIMES Magazine, March 18, 2007 (discussing the lingering effects of the institution of slavery in modern Ghana). Bridget Anderson \& Julia O'Connell Davidson describe the treatment of women exploited as sex and domestic workers:

The racially/ethnically different worker is not perceived as an equal human being and so can be used and abused in ways that would be impossible in respect of workers of the same race/ethnicity. The migrant worker comes from an impoverished, "uncivilized," "backward" country and so is neither familiar with nor entitled to the rights, freedoms and respect owed to local workers . . . .

Bridget Anderson \& Julia O'Connell Davidson, Is Trafficking in Human Beings Demand Driven? A Multi-Country Pilot Study 42 (2003). 


\section{d. Gender}

Unlike the trans-Atlantic slave trade, where African and Africandescended individuals of all ages and both sexes were subject to the same risk of enslavement, women and children appear to be more likely than men to become victims of the modern traffic in human beings. ${ }^{311}$ Analysis of this difference in the two phenomena leads to at least three potential explanations.

The first potential explanation stems from the subordination of women and children in many cultures, which may increase vulnerability to traffickers. Firstly, in economic and social terms, women and children may be viewed as less valuable than are men with respect to their earning power, likelihood of being educated, and contributions to the family unit. Secondly, women and children in the majority of societies are trained and expected to be subservient, obedient and easily directed. The social, economic, and psychological subordination means that the young child - and especially the young girl child - may be sold or rented out by the family unit since s/he may represent an investment that is not expected to bring worthwhile returns. Further, the psychological training in subservience may create a victim with diminished capacity to resist his or her captors, while the possibility of resistance is further constrained by the comparatively weaker physical strength. In addition, the societal expectation of the subordination of women and children in both source and destination societies may make such victims easier to hide and control, even in plain sight, as such subordination may fit into the default reality of such societies.

The second potential explanation of the apparent gender disparity in victimization is that the data showing the comparatively greater exploitation of female and minor victims ${ }^{312}$ by modern traffickers may be affected by the expectations of data collectors. For example, the image of women and children as the quintessential trafficking victims may have affected the data collectors, so that they may expect that women and children will have been exploited and will be better able to identify and count them. In contrast, the exploited adult males may not attract the attention of the data collectors. Alternatively, the data collection by developed country NGOs and interest groups may be affected by those groups' perceptions of the subordinated status of women and children in developing country societies, so that female and minor victims are more easily identified and counted.

The third potential explanation points to the impact of definitions on data collection. To the extent that the definitions utilized to identify and target modern trafficking focus on the types of exploitation experienced

\footnotetext{
311 See supra note 129.

312 Their exploitation is statistically greater when compared to the relative exploitation of men, women and children in trans-Atlantic slavery and of adult males in the modern traffic in humans.
} 
by women, while ignoring the exploitation experienced by men, the "trafficking" of women may play out more visibly in the data gathering and media arenas. For example, the sex trafficking of women is targeted and may be more readily identified than the labor trafficking of men. ${ }^{313}$ Another clear example of this is the definitional distinctions between human smuggling and the trafficking in human beings. As discussed earlier in the Article, the differences in the two definitions appear to reflect the interests and compromises of states parties to the relevant conventions, rather than real world differences in the experiences of victims. ${ }^{314}$ In addition to the biases already identified, the definitional distinctions may also reflect and foster underlying gender stereotypes.

\section{Economic Structure}

An exploration of modern trafficking in humans and the trans-Atlantic slave trade would be incomplete without a comparison of the economic aspects of modern trafficking in humans and of the trans-Atlantic slave trade. The exploration and comparison done here is necessarily superficial, incomplete and speculative - some illustrative aspects of the economic characteristics of the two trades are selected and examined, leaving for further research and analysis the definitive comparison of the economic structure of the two trades.

\section{a. Integration into "Legitimate" Economy}

Trans-Atlantic slavery was a centuries'-long international trade in people and their labor. The dominant conception of the modern traffic in humans is that it is an abnormal parasitic appendage to global and domestic economies, the product of the greed of certain monstrous individuals and groups. An examination of various aspects of the economic underpinnings of the two forms of exploitation reveals, however, that modern trafficking in human beings is as interconnected with and central to contemporary domestic and global economies as was the trans-Atlantic trade and slavery to its contemporaneous economic systems. ${ }^{315}$

313 See supra note 142 (citing reports of labor trafficking of Polish and Mexican men in Italy and Florida, respectively).

314 See supra notes 103 - 108 and accompanying text.

315 David Brion Davis makes an explicit connection between the interconnection of today's global economy and the relationship between slavery in the American South and the industrial capitalism of the Northern states: "Like some of the later Third World regions where involuntary labor produced raw materials for industrial nations, the South was intimately connected with industrial capitalism and yet cut off for various reasons from its liberalizing and diversifying influences." DAvis, InHUMAN Bondage, supra note 25 , at 185 . See also id. at 184 for Brion Davis's discussion of the interconnectedness of the slave economy with the broader "nonslave" economy. 


\section{i. Stimulus for the Trade}

The similarity in the economic aspects of the two types of trade in human beings is clear. Both are based on a demand for labor, and the seller-owner participants in both phenomena attempt to satisfy that demand. Trans-Atlantic slavery sprang from the demand for labor in the New World, a demand that, for various reasons, could not easily be satisfied by either the migration of colonists from Europe or the enslavement of the indigenous people. To fill that gap in their productive capacity, the New World colonizers and their empires resorted to the importation of coerced labor, i.e., slaves, from Africa. ${ }^{316}$ Similarly, modern trafficking is caused by unfulfilled demands for labor, and is founded on labor shortages in some states and an excess of unused labor in others. Like the slave traders of the trans-Atlantic trade, the modern traffickers in human beings are supplying a factor of production essential to the economic activity of the market economies in which they operate.

One clear distinction between modern trafficking in human beings and the trans-Atlantic slave trade is the level of participation and agency of the regions, individuals, and entities that participate in the traffic. Through the trans-Atlantic slave trade, the European powers imposed upon Africa a mass-production industrial market in humans, a trade that, while already taking place between sub-Saharan Africa and the Middle East and North Africa, was not as widespread as it would become under European tutelage. Through that trade, Africa was forced to participate more actively in the global economy, and to specialize in the supply of a factor of production - Africa's human capital - specialization in which had detrimental effects on Africa's later development. ${ }^{317}$ In contrast to the African continent's coerced participation, the entrepreneurial traders of the modern trade in humans are willing and eager participants in this contemporary wave of globalization. Through the traffic in human beings, they seek to satisfy the contemporary global economic need for ever cheaper labor.

\section{ii. Type of Labor}

One distinction between the two trades may be that in trans-Atlantic slavery, the slave trader's function was to fill the gap created by the absolute shortage of available labor required to fulfill the economic needs of the New World colonies. By contrast, in the modern traffic in humans, the trafficked victims perform labor for which manpower may be available, but which that available manpower considers undesirable and refuses

316 As discussed supra, the decision to import enslaved Africans satisfied two complementary demands - the need for labor, and the need to identify the slaves among the colonists for easier control of the enslaved.

317 See, e.g., Nathan Nunn, The Long-Term Effects of Africa's Slave Trades (Nat'l Bureau of Econ. Research, Working Paper No. 13367, Sept. 2007), available at http:// www.nber.org/papers/w13367. 
to perform. The distinction may be summarized as: trans-Atlantic slavery = not enough people or labor versus modern human trafficking $=$ the performance of undesirable, degrading, or insufficiently compensated work.

One may more easily visualize the similarity in economic stimuli leading to the flourishing and expansion of the trade by looking beyond the stereotypical sex-trafficking tropes to the reality of the great diversity in the industries for which modern victims of trafficking are destined. The circumstances of modern trafficking's exploitation of victims are as varied as the tasks to which black slaves of the trans-Atlantic trade were destined. ${ }^{318}$ Further, even if one looks only toward the segment of the market that specializes purely in the trafficking of individuals for sex, the similarity with the trans-Atlantic slave trade is not overcome. Although the majority of slaves during the era of the trans-Atlantic slave trade were destined for more "prosaic" roles in the economic activities of the slave society, in addition to the quotidian opportunistic sexual exploitation of slaves by their owners, there was a very active "fancy" trade specializing in the marketing, for sexual exploitation, of enslaved African and African-descended women by their owners. ${ }^{319}$

\section{iii. Greed vs. Profit-Seeking}

A distinction in the economic sphere often made between modern trafficking in humans and the trans-Atlantic slave trade aims at the motives of the trader-owner participants. The rhetoric that invokes the transAtlantic slave trade to mobilize action against the modern traffic in human beings often inveighs against the greed of the modern trafficker. ${ }^{320}$ However, as Willem van Schendel and Itty Abraham note, "[m]any key words are reserved for the bad guys and their organizations .... . Such language constructs conceptual barriers between illicit bad-guy activities (trafficking, smuggling) and state-authorized good-guy activities (trade, migration) that obscure how these are often part of a single spectrum." 321 Greed may be understood as the desire to make

318 See, e.g., McKee, supra note 14, at 161 ("The jobs in which victims of modernday trafficking are placed are diverse . . . trafficked workers may be placed as ... household domestics, food industry workers, or prostitutes.").

319 See Deborah Gray White, Ar'N't I A Woman?: Female Slaves in the Plantation South 34-37 (rev. ed. 1999) (describing the sexual exploitation of female slaves); and 37-39 (describing the "Fancy Trade" specializing in the traffic of light-skinned women of African descent "for the exclusive purpose of prostitution and concubinage").

320 For example, Ambassador John R. Miller, supra note 198, at 39 ("Greed generates many categories of slavery, such as domestic servitude, child soldiers, factory, and farm labor slavery. There are exotic forms of slavery - such as child camel jockey slavery - in many of these countries.").

321 See Willem van Schendel \& Itty Abraham, Introduction: The Making of Ilicitness, in Illicit Flows and Criminal Things 9 (Willem van Schendel \& Itty Abraham eds., 2005). 
profit, the desire for profit being an inevitable, necessary, and oft-celebrated element of a market economy. The greed of the modern trafficker in human beings is merely the desire for profit, and the word "greed" is employed to characterize as illegitimate a central tenet of economic theory (profit-seeking) that society and economic theorists celebrate when speaking of legitimate industries on which society and the legal system have conferred approval. The greed or profit motive of today's ownerparticipants in the traffic in human beings is not different from the greed or profit motive of either the trans-Atlantic slaver or the modern entrepreneur. $^{322}$

\section{iv. Profitability}

A further distinction asserted regarding the two forms of human exploitation is based on the argument that the new slavery is much more profitable than the old. The purveyors of this argument ${ }^{323}$ imply that modern trafficking is even more aberrational than trans-Atlantic slavery and the slave trade because modern slavery is more profitable. The supporters of this argument point to the re-usability and long-term profitability of humans converted to merchandise in contrast to the traffic in drugs or arms, for example. ${ }^{324}$ The profitability of modern human trafficking is said to be based on the ability to exploit human victims, without relinquishing ownership or control to the end-user or customer. ${ }^{325}$

This argument reflects a common misconception with respect to the economic underpinnings of trans-Atlantic slavery and the confluence of factors that led to its eventual legal prohibition. Contrary to Bales's statements, black slave labor continued to be economically efficient up to the Civil War in the United States and the abolition of slavery in the British Empire. ${ }^{326}$ The scholarly literature undermines the assumption of the unprofitability and inevitable collapse of trans-Atlantic slavery. ${ }^{327}$ Trans-Atlantic slavery and the slave trade continued to be profitable to

322 See Davis, InHUMAN Bondage, supra note 25, at 181 (describing the strong economic basis for the trans-Atlantic slave trade and slavery).

${ }^{323}$ Bales, for example, makes a distinction between unprofitable old slavery and profitable new slavery. See Bales, Disposable People, supra note 5, at 15-16.

324 See, e.g., Tiefenbrun, supra note 63, at 141.

325 See id. at 140-141 ("Buying women who are trafficked is a limited investment; but the sale of their services continues to generate profits long after the initial outlays have been covered. In the drug trafficking industry, the high priced and highly sought after narcotics product can be sold only once, but when you commodify a human being she can be sold over and over again; thus, the potential profits in the sex trade industry are high ...").

326 See Davis, Inhuman Bondage, supra note 25, at 356 (fn. 4), and 106-107.

327 See id. at 181 ("Scholars still dispute some questions relating to the economics of American slavery, but during the past thirty years a broad consensus has confirmed the arguments ... . concerning the extraordinary efficiency and productivity of plantation slave labor, which in no way implies that the system was less harsh ...."). 
the very end, and there appears to be no economic reason why transAtlantic slavery and the slave trade should not have continued to the present day. ${ }^{328}$ It was the pressure of moral, political, and ethical forces and arguments, rather than economic factors, that led to trans-Atlantic slavery's "demise." 329

\section{b. Valuing Human Merchandise}

Another economic comparator that may be useful in evaluating the analogy between trans-Atlantic slavery and modern trafficking in humans is the value of human "merchandise." The claim is often made that today's slaves are cheaper and more disposable than the victims of old slavery (including, implicitly, trans-Atlantic slavery). ${ }^{330}$ However, this claim is based on economic factors that subordinate, but do not nullify, the modern era's appreciation for human rights.

Yet why make this claim at all? What purpose may be fulfilled in the policy-making rhetoric by asserting that or answering the question whether modern slaves are cheaper than were the slaves of yesteryear? Does it or should it matter that slaves are cheaper now? Those who propose the distinction seem to imply that this difference makes modern slavery worse, reflecting a cheapening of the value of human life in an era when, following the flowering of human rights recognition and enforcement after World War II, such cheapening and/or exploitation appears ever more egregious to the eyes of society. However, the price - whether the human being is sold high or low - should not affect our appreciation and horror of the sheer commodification of human life epitomized by both modern trafficking and trans-Atlantic slavery.

\section{i. Value and Chattel Slavery's Effect}

As discussed earlier in this Article, ${ }^{331}$ the legal status of slavery has been fundamentally transformed: while, in the era of the trans-Atlantic slave trade, the ownership of human beings and their status as chattels were legally recognized and enforced, such ownership is prohibited under international law and the domestic legal regimes of the vast majority of states. This transformation of the legal status of slavery has a fundamental impact on the economics of modern trafficking, including its effect on the monetary "value" of the victims of the traffic.

328 See id. at 181-84 (discussing the economic health of Southern slave economy, its similarity and precursor role with respect to modern factory production, and speculating that it could have continued profitably into modern times).

329 As discussed infra, however, that "demise" merely served to mutate the form of enslavement and exploitation that was utilized, and did not end de facto incarnations of slavery.

330 See e.g., Bales, Disposable People, supra note 5, at 14-16 (claiming that slaves are cheaper and more disposable today than were the victims of "old slavery"). 331 See supra Part V.B.1. 
The enforcement of ownership under trans-Atlantic slavery allowed the trader-owner to leverage the value of his chattel, as demonstrated in the use of human slaves, much like the use of animal and non-live chattel, in securing and mortgaging debt, working off debt, and inter-generational transfers. ${ }^{332}$ While the financial institutions of the trans-Atlantic slave trade era could and did extend credit based on the value of those slaves, with the knowledge that the legal system would enforce ownership rights and liens upon them, no reputable legitimate international or domestic institution today would make such a loan. The ability to leverage the legally protected ownership of human chattel inevitably made those slaves more valuable to their owner than are the victims of modern trafficking. In order to make similar use of their victim-slaves, it is perhaps possible that modern traffickers could resort to other participants in illicit enterprises who might have the interest and resources to extend credit to the enterprise. On the whole, however, the transformation of the status of slavery has limited the trafficker-owner's ability to legally exploit and leverage the interests in his/her slaves, thus contributing to a diminution in the slave's intrinsic monetary "value."

\section{ii. Disposability}

A central tenet of Kevin Bales's comparison of old and new slavery is that, in contrast to the victims of "old slavery," the victims of new slavery (including the modern traffic in humans) are disposable. ${ }^{333}$ Bales emphasizes that the owner-trafficker has little incentive to care for the victim, as a result of the ease and cheapness of replacement. However, this posited distinction between the attitudes of owner-traffickers cannot be generally substantiated - both the life expectancy and replacement rates of slaves in the New World, as well as the mortality rates during the voyages to market from Africa to the New World, emphasize the similarities in the

332 For example, slave statutes in South Carolina and Kentucky provided, respectively:

Slaves shall always be reputed and considered real estate; shall, as such, be subject to be mortgaged, according to the rules prescribed by law, and they shall be seized and sold as real estate.

Statute of June 7, 1806; 1 Martin's Digest 612 reprinted in WILliam Goodell, The American Slave Code in Theory and Practice: Its Distinctive Features Shown by Its Statutes, Judicial Decisions, and Illustrative Facts 10 (1823) (emphases added).

By the law of descents, slaves are considered real estate, and pass in consequence to heirs, and not to executors.

2 Littell \& Swigert's Digest, 1155, id. (emphases added). Reverend Sharpton's greatgreat grandfather was transferred to the possession of Strom Thurmond's relatives in order to enable the widowed dependent to hire him out as a means of paying off the debts of her deceased husband. See supra note 298 (discussing the revelations about Reverend Sharpton's ancestors).

333 See Bales, Disposable People, supra note 5. 
owner-traffickers' perception of the disposability of their merchandise. It is the drive for profits, not the intrinsic "value" or disposability of the merchandise, that determines the parameters of the exploitative structure as the owner-trafficker exploits his market.

Bales's argument appears to rest on comparing "old" slavery as epitomized in the American South after the United States' prohibition of the slave trade in 1807 decreased the supply of slaves and increased prices rather than on a wider inquiry into the varying incarnations of slavery in the New World or elsewhere. ${ }^{334}$ The scholarly literature makes clear that slave-victims of the trans-Atlantic slave trade and slavery were just as disposable as today's victims of trafficking. David Brion Davis reported that "a Brazilian sugar planter could double his investment if an adult slave lived and worked for only five years," that in the "late-seventeenthand eighteenth-century British and French Caribbean ... planters often affirmed that it was much cheaper to work slaves to death and buy replacements from Africa than to 'breed' new generations of slaves from infancy," and "that Brazilian sugar planters calculated that it was cheaper to buy imported African slaves than to pay the costs of raising black children to adulthood."335 And, discussing the mortality rates during the trans-Atlantic section of the triangular trade, Eric Williams noted that " $[\mathrm{t}]$ he mortality in the Middle Passage was regarded merely as an unfortunate trading loss, except for the fact that Negroes were more costly than cattle. Losses in fact ran quite high, but such concern as was evinced had merely to do with profits." 336

\section{iii. Sourcing and Recruitment: Methods}

Other economic characteristics of the two systems of trafficking in human beings that should be considered include the impact of the costs and profitability of the mechanisms and logistics of recruiting the human "merchandise." Some aspects that will be examined include comparing the methods of transporting the merchandise to market and the greater or lesser availability of the merchandise.

During the trans-Atlantic slave trade, human merchandise was sourced from one continent - Africa. As discussed before, the distinctiveness of the racial characteristics of Africans resolved slave owners' concerns

334 In Inhuman Bondage, Brion Davis noted that "in Brazil and much of the Caribbean, unlike the United States and earlier British North American colonies, slaves never achieved a positive growth rate that would have lessened the system's dependence on continuing importations from Africa. In northeastern Brazil, in the late eighteenth century, a slave's life expectancy at birth was approximately twentythree years, or twelve years less than that of an American slave in 1850." Davis, INHUMAN BONDAGE, supra note 25, at 117 (emphasis added).

${ }^{335}$ Id. at 116.

336 WILLIAMS, supra note 177, at 139. 
regarding identification and control of their chattel. ${ }^{337}$ The racial slavery of the trans-Atlantic slave trade restricted the "recruitment" activities of the owner-traffickers to the African continent and surrounding islands. A restructuring in the market for human beings, combined with the increasing interconnectedness - economic, cultural, and other - of the world has broadened the available sources for obtaining human victims. In addition, as discussed earlier, ${ }^{338}$ since the owner-trafficker no longer needs or desires that his merchandise be distinct from the general population, since control is now premised on the legal system and society's lack of knowledge of exploitation or failure of enforcement of victims' rights, the profitability of the enterprise now derives from exploiting the economic, rather than racial, vulnerability of potential victims.

The opening up of supply sources for human merchandise owes much to the movement away from a racial distinction toward economic distinctions. While the binary (black or white) distinction of trans-Atlantic slavery restricted the owner-traffickers to sourcing their merchandise in Africa, contemporary exploitation of economic, rather than mere racial, vulnerability, allows the owner-trafficker a wider range of choices. Today's victims of human trafficking are sourced from all continents, so that a worldwide market in humans is available to the trafficker-participants in this trade. As a result of the elimination of the need to specialize in enslaving a single racial category of humans, the contemporary trafficker may decrease the costs of recruitment to increase profitability of his enterprise. For example, the Eastern European traffickers discussed by Shelley ${ }^{339}$ may increase profits earned from their participation in the industry by sourcing their human merchandise domestically or from contiguous neighboring countries. ${ }^{340}$ By contrast, the owner-participant in the trans-Atlantic slave trade, to the extent that excess slaves were

\footnotetext{
337 See supra Part V.B.2.c.

338 See id.

339 See supra notes 164- 170 and accompanying text.

340 A noteworthy aspect of the supply structure of both the trans-Atlantic slave trade and the modern traffic in humans is the active participation of racial and ethnic groups in engineering and exploiting the enslavement of members of their own group. Even if one ignores the reality that there was no pan-African identity at the time of the slave trade (if one even exists today), it is still striking that African slave traders enslaved and traded people who looked like themselves to people who appeared to be so starkly different. Davis, Inhuman Bondage, supra note 25, at 88 ("it is crucially important to recognize that Europeans profited from the total lack of any "panAfrican consciousness.' Similarity in skin color and other bodily traits (as Europeans viewed them) brought no sense of a common African identity."). Similarly, in the modern traffic, traffickers practice equal opportunity exploitation, preying on victims from their own groups and countries, as well as foreign women. See Chuang, supra note 13, at 69 ("racial factors can drive international trafficking across borders for the purpose of recruiting foreign women to meet the racial preferences of certain brothel clientele"). See also id. at 72:
} 
unavailable for trade domestically, faced the continual challenge of crossing the Atlantic in order to procure new merchandise. ${ }^{341}$

In this regard, Kevin Bales speaks of a shortage of potential slaves in the era of the trans-Atlantic slave trade. The human merchandise was certainly more difficult to obtain, but it is unclear that there was an actual shortage that would affect the price. ${ }^{342}$ Such shortage as emerged during the nineteenth century was due to the British and American prohibition against supplying the human merchandise from Africa, which disrupted the existing supply chain.

\section{iv. Sourcing and Recruitment: Victim Agency}

Another factor that contributes to the perception of or actual difference in the value of human merchandise trafficked in both systems of exploitation is the methodology of recruitment. The "recruitment" of individual slaves in trans-Atlantic slavery owed little to the agency ${ }^{343}$ of the victims - merely by existing as Africans in regions that suffered the depredations of the trans-Atlantic slave trade, Africans lived in constant danger of enslavement and could be "recruited" into the trade. By contrast, today's victim-slaves (much as the victims of white slavery) some-

To the extent that these women feel they can return to their native villages, they often do so not as victims returning home with hopes of establishing a new life, but as recruiters in search of girls - either to take their own places and thus secure their own release from bondage, or to establish their own brothels.

341 This "scarcity of supply" aspect of the economics of trans-Atlantic slavery, for example, illuminates the economic as well as racial reason why, in most societies, the default legal rules provided that the slave's status was inheritable. The inheritability of slave status ensured a larger pool of potential victims to the slave owner, and ensured that expenditures toward the "upbringing" of the children of the ownertrafficker's slaves would be recouped. Indeed, in some slave societies, slave owners participated actively as instigators (through arranged couplings) of and progenitors in the production of their slaves' replacements. See, e.g., Neal Kumar Katyal, supra note 14 , at 798-800 (describing the sexual exploitation of female slaves in the antebellum South, including their purposeful "breeding," and citing to contemporaneous sources). See also Pamela D. Bridgewater, Ain't I A Slave: Slavery, Reproductive Abuse, and Reparations, 14 UCLA WomeN's L.J. 89, 119 (2005) ("[S]exual assault of female slaves became a wise investment strategy for cash-strapped slave owners interested in increasing the number of their slaves, even if they had to wait for the infants to become productive.").

342 See, e.g., Davis, Inhuman Bondage, supra note 25, at 244:

Clearly the economic costs of such abolitionist policies were extremely high. During the first six decades of the nineteenth century, there was more than an ample supply of slaves on the African coasts. Since the "culture of enslavement" continued to operate in Africa long after the sharp drop in European demand, the number of slaves in West Africa soon surpassed the number in the New World. Hence the price of slaves remained relatively low and stable. Yet throughout the American plantation societies, slave prices continued to rise in response to labor shortages.

${ }^{343}$ That is, the ability to make autonomous decisions or the exercise of free will. 
times play a more active role in their own victimization - they answer newspaper ads, travel across borders, and otherwise play an active role in seeking to exchange their labor for value. However, modern trafficking's and white slavery's victims' agency is and was circumscribed by the very limited choices available to the modern trafficked victim and the white slaves - the choice between seeking economic advantage and a better standard of living versus taking no action and failing to survive, or continuing to live in poverty or disadvantaged circumstances. ${ }^{344}$

\section{v. Sourcing and Recruitment: Interrelationship of Costs and Supply}

Several benefits accrue to the owner-trafficker of the modern traffic in humans from the "participation" of victims. The victim's participation in his/her own recruitment, in contrast to the lack of active economic participation of the victim of the trans-Atlantic slave trade, serves to offset the recruitment costs of the owner-trafficker. Today's victims sometimes pay part of their own costs of transport. The owner-trafficker needs to recoup less money from his/her own investment. The economic structure of this modern industry also serves to cheapen the value of the "victim-slave:" the owner-trafficker has invested fewer resources to acquire the slave, may need to "sink" less capital into acquisition of the victim-slave, and therefore needs to extract less value from the victim-slave in order to earn a profit.

Further contributing to the decline in the relative value of the modern trafficking victim, vis-à-vis the slave-victims of trans-Atlantic slavery, may be the changes in modes of transportation of human merchandise, including greater availability of such transportation. Transporting the "merchandise" to market may be easier and cheaper than it was during transAtlantic slavery. In the era of the trans-Atlantic slave trade, the costs of sourcing the merchandise included, for trans-Atlantic voyages, the costs of maintaining and operating a ship, employment and feeding of a crew of sailors, payments to native procurers (including the financing of "tribal" wars), ${ }^{345}$ feeding and maintaining the merchandise during the transAtlantic journey, as well as the risk of loss stemming from revolts and high mortality rates. For domestic sourcing, such as the movement of merchandise from the upper to lower Southern states (especially after the American slave trade was prohibited), similar costs of overland passage were incurred. In contrast, the transport costs of the modern trafficker are much different. The merchandise moves across international borders

344 See Cockburn, supra note 106, at 23: "'Back then,' said Dottridge, 'black people were kidnapped and forced to work as slaves. Today vulnerable people are lured into debt slavery in the expectation of a better life. There are so many of them because there are so many desperate people in the world.'" (quoting Mike Dottridge, former director of Anti-Slavery International).

345 See, e.g., Edward Ball, Slaves in The Family 135-136 (1999). 
via air, water, or land-based transportation systems that the slaver need not own or maintain, the slave-victim contributes to payment of his/her own costs, and the availability of modern medical intervention lowers the potential mortality rate so that even if the trafficked person is more disposable to the trafficker, it is easier to maintain the individual in a minimally functional exploitable state so as to extract a profit prior to disposal. All costs appear to be lower, even if the owner-trafficker and his/her organization must pay the costs of corrupting local officials to encourage them to turn a blind eye. Indeed, corruption costs are a cost of doing business, analogous to, and perhaps no less costly than, the costs of inciting "tribal" wars.

Kevin Bales also points to the increase in the world's population and consequent increased availability of potential victims as a factor that leads to the decrease in the cost of and greater disposability of the trafficking victims. Overpopulation also makes the "product" less expensive. This factor is also linked, as well, to the opening up of the limitations on racial groups that may be enslaved or victimized. The mono-racial sourcing of merchandise during trans-Atlantic slavery restricted the supply of victims to one race, which, in tandem with that race's origins on one continent, limited the source to a subset of the then-smaller world population. The larger and more varied population from which the modern owner-trafficker may choose leads to a greater ability to specialize in the type of product - both with respect to the labor performed and the race of the product. So, for example, today's owner-trafficker may specialize in Asian, European, or other victims, depending on the tastes of his/her end-user. Some similar specialization took place in trans-Atlantic slavery, within the confines of a single racial group. For example, the ownertraffickers of the trans-Atlantic slave trade knew of the desirability and therefore greater profits that would accrue from procuring Africans from certain regions for the rice fields of North Carolina. ${ }^{346}$

Bales, among others, has pointed out that victims of modern trafficking are more disposable because their traffickers no longer need them to breed their own replacements. This contrast between the business models of trans-Atlantic slavery and modern traffic in humans is due also to the change in the ways in which the supplies of potential victims are identified. This change is more closely related to economic factors than to the owner-traffickers" greater disregard for the "humanity" of their victims. Instead, the economic and legal framework within which the owner-trafficker works contributes to the determination of the "value" of the slave. In this case, since the inheritability of the status of the trafficking victim will not be enforced by the contemporary legal or moral and ethical systems, the owner-trafficker would gain no monetary value from encourag-

${ }^{346} I d$. at 103, 178-179 ("Slaves from the region the traders called Sierra Leone... were regarded as good all-around 'rice Negroes,' because they had grown rice for centuries."). 
ing or maintaining the as-yet unexploitable offspring of his/her own victims. Instead, the owner-trafficker may easily procure replacements from the continuing supply of economically vulnerable potential victims.

\section{State Complicity}

A further area of comparison of the trans-Atlantic slave trade and the modern traffic in humans is the role of states or empires in creating preconditions for the trade and fostering its continuation. The empires of yesteryear actively participated, economically, politically, and legally in the creation and maintenance of the trans-Atlantic slave trade. Today, despite the mobilization by state actors of anti-trafficking efforts on international and domestic fronts, such actors play a role in modern trafficking.

In trans-Atlantic slavery, states and empires created the legal framework designed to facilitate and enforce the enslavement of Africans and their descendants. The interests of slave-trading empires were served, in the era of the trans-Atlantic slave trade, by open borders that brought floods of coerced African labor to the shores of the New World. Today, the barriers of state-maintained international borders and laws regulating the movement of people serve to limit the natural flow of labor that might create equilibrium in labor markets. The successors to those empires, in short-sighted attempts to protect advantages gained through their colonial pasts, now seek to protect their predominance through the erection and maintenance of barriers to the entry of those "others." As individuals in labor rich states attempt to cross state borders to access the labor markets of labor-poor states, the border regulation and enforcement systems put in place by states create barriers to their movement, driving them, in many cases, into the arms of human smugglers and traffickers. ${ }^{347}$ As has been well-documented, many would-be migrants find that there is a porous border and a short step between the status of a smuggled person and the status of trafficking victim. ${ }^{348}$

In the slave societies of the era of the trans-Atlantic slave trade, the slave was a quasi-person, the attributes of personhood serving the interests and profit-seeking of the slave society. In modern societies and states, crouched defensively against the influx of would-be migrants, states have begun to withhold the attributes of full personhood from those who have either entered their borders illegally or, having entered legally, have remained past the legally mandated limit of their stay. The immigration laws employed by the United States, for example, serve to

347 See Zalewski, supra note 87, at 120 ("The relationship between the exorbitant number of people wishing to migrate and the limited legal opportunities available to do so contributes to the recent increase. Both the lack of legal opportunities and restrictive domestic immigration policies force individuals to resort to trafficking.") (citations omitted; emphasis added).

${ }^{348}$ See, e.g., supra note 106. 
facilitate and enforce enslavement and subjugation of economically vulnerable people. ${ }^{349}$ State immigration laws, and their domestic and international enforcement, function in effect like the "patterollers" 350 and Black Codes of the American South.

States, therefore, may be said to be complicit in creating and enforcing the vulnerability of some populations. That accusation is not negated by the mobilization of state resources against human trafficking. The effect of criminalization, much like the U.S. prohibition of its trans-Atlantic slave trade ${ }^{351}$ is to move the trade underground, and perhaps to make more vulnerable the victims of the trade. Failure is not the only risk springing from the ineffectiveness of neo-abolitionism. Other dangers include the further condemnation and repression of developing world socalled "source countries" and their nationals. Taking the long-term view, and interrogating the mechanisms of the current fight against modern trafficking, the question arises whether the current anti-trafficking campaign functions to continue the domination and stigmatization of the developing world. ${ }^{352}$ As David Brion Davis points out, "[e]mancipators can be as coercive and oppressive, in subtle ways, as enslavers. It was not the enslavers who colonized and subjugated Africa, but the European liberators." ${ }^{353}$

349 See, e.g., Kevin R. Johnson, Open Borders?, 51 UCLA L. REv. 193, 226-230 (2003) (describing how restrictive immigration laws and court decisions limiting the rights of undocumented immigrants facilitate the exploitation of undocumented immigrants and other non-citizens in the United States).

350 Southern roads were constantly patrolled by groups on the lookout for blacks traveling without a pass. See, e.g., Bullwhip Days: The Slaves Remember: An Oral History 139-40 (James Mellon, ed., 1988).

351 Davis, Inhuman Bondage, supra note 25, at 15 (describing the illicit transAtlantic trade conducted by U.S. vessels following the 1807 prohibition against the slave trade). See also Ron Soodalter, Captain Gordon's Infamy, SMithsonian MAGAZINE, June 2007 at 58 (describing lack of enforcement of U.S. laws prohibiting the trans-Atlantic slave trade).

${ }^{352}$ For example, the TIP report condemns source countries more than it does destination countries and, as noted by Professor Chacón, "current anti-trafficking efforts all but ignore the role of the internal policies of receiving countries like the United States." See Chacón, supra 150, at 3039.

353 See Davis, Slavery and Human Progress, supra note 37, xvii; Binder, supra note 181, at 2075 :

Even sincerely motivated moral crusades to suppress slavery carry risks to freedom. Implicit in the role of emancipator is a claim of political authority that may be grounded in cultural condescension to barbaric masters and helpless slaves alike. Thus the "international" crusade against the slave trade served to legitimize first British domination of Caribbean trade and finally British rule over much of Africa .... In sum, mass manumission, like individual manumission, has rarely ended the subordination of the slaves. Conceived as the manumission of individuals, mass manumission may deplete or even empty slavery as a social category without eliminating it as an institution and a set of cultural assumptions that structure power relations. 
The comparative analysis of the legal, psychological, social, and economic aspects of the modern traffic in humans and the trans-Atlantic slave trade reveals their fundamental similarities and exposes the superficialities of the uses made, thus far, of the analogy to the trans-Atlantic slave trade. Both are part of, bound by, and responsive to the legal, economic, and social forces of their times. Both the trans-Atlantic slave trade and the modern traffic in human beings are products of the entrepreneurial endeavors of human beings who exploit the vulnerabilities of other humans to the extent permitted or facilitated by the contemporaneous legal, economic, and social systems. The degree of exploitation, the manifestation of exploitation, the experience of exploitation, and the permanence or impermanence of its effects for particular individuals and societies may vary but, fundamentally, human-tohuman exploitation is pursued in return for gain.

\section{Conclusion: Beyond Neo-Abolitionism}

The experience of the seventeenth to nineteenth centuries had fixed in the Western mind the idea that slavery was an institution in which black people were owned as property. ${ }^{354}$

The analogy between the trans-Atlantic slave trade and the modern traffic in humans may appear to be particularly apt and may be deeply ingrained because of the visceral and deep-seated image in the public and policy-making mind, but is next to useless and merely sensationalist and exploitative, if it is not fully harnessed in the fight to combat the modern traffic. Professor Yuen Foong Khong's warnings about the potential misuses of analogical reasoning ${ }^{355}$ are well-taken. The analogy has been misused because of the superficiality of the comparison - a failure to explore more fully the fundamentals of the two phenomena - and the exploitative nature of the analogy's use. ${ }^{356}$

Ethan Kapstein advised that "[j]ust as the brutal facts of the Atlantic slave trade ultimately led to a reexamination of U.S. history . . . so must growing awareness of the modern slave trade spark a recognition of the flaws in our contemporary economic and governmental arrange-

(citations omitted).

${ }^{354}$ Bales \& Robbins, supra note 242, at 22-23 (emphasis added).

355 See supra notes 183-188 and accompanying text.

356 An interesting tactical question that is not fully explored in this Article centers around the question of the degree to which the most lurid elements and arguments should be emphasized in order to galvanize and motivate individuals, groups and societies that might otherwise be indifferent. A canny tactician must be aware of both the positive and negative powers of her weapons. The use made thus far of the analogy to the slave trade has failed to use its full power to fight the modern traffic in humans and to limit damage that may ensue from careless invocation. 
ments." 357 The analogy to the trans-Atlantic slave trade leads to a more comprehensive and potentially more effective framework for combating the modern trafficking in human beings than do the legal and conceptual frameworks currently employed. However, the power of the images and expectations constraining the minds of those who battled white slavery continues to constrain the minds, mechanisms, and paths of inquiry of those who steer the fight against human trafficking.

The challenge to plumb the depths of the analogy to truly seek understanding of the modern traffic in humans merely begins here. Comparisons of the modern trafficking in humans and the trans-Atlantic slave trade reveal the essential nature of the two phenomena - at bottom, they both trade in human labor. ${ }^{358}$ The growth of the nation state and the concomitant increase in the legislative and other barriers to the movement of peoples has driven and continues to drive the movement of people and their labor underground. To exist, survive, and thrive, human beings seek to exchange their labor for value - and migrants respond to market forces that promise higher prices for that labor across international borders. ${ }^{359}$ The modern traffic in persons includes many more factors and causes than the greed of "monstrous" traffickers. The trade presents significant economic opportunity to those who may have limited access to legitimate enterprises, and for whom a form of human capital and commodification of that capital is the most readily available resource that may be profitably exploited.

Willem van Schendel and Itty Abraham urge that "[w]e need to approach flows of goods and people as visible manifestations of power configurations that weave in and out of legality, in and out of states, and in and out of individuals' lives, as socially embedded, sometimes longterm processes of production, exchange, consumption and representation." 360 Rather than a peculiar institution, slavery has been an integral part of human existence. Whether or not institutionally, morally or

357 See Kapstein, supra note 5, at 103.

358 See, e.g., Kolchin, supra note 27, at 14 ("The initial demand for labor that eventually led to slavery was . . .color-blind."); and U.S. State Department, Trafficking in Persons Report, June 2004, at 6 ("[T] he 21st century slave trade feeds a global demand for cheap and vulnerable labor.") (emphasis added). The distinctiveness of the Africans' skin color and other racial characteristics served the identification and control purposes of the enslavers. See Davis, InHuman Bondage, supra note 25 , at 34 ("While slaves in antiquity could usually be recognized by clothing, branding, collars, and other symbols, the millennia-long search for ways to identify 'natural slaves' would eventually be solved by the physical characteristics of sub-Saharan Africans.").

${ }^{359}$ If the comparative advantage of some - usually developing - countries is their abundance of available labor, individuals and organizations from those countries should be able to freely trade their labor internationally, ideally within the institutional framework of the GATT/WTO system.

360 Van Schendel \& Abraham, supra note 321, at 9. 
socially condoned, it has always been with humankind. ${ }^{361}$ Professor Derrick Bell suggests that the United States Constitution's inherent contradictions represent the sacrifice of one group's interests - the African slaves - on behalf of other interests - survival of the Union. ${ }^{362}$ Modern traffic in humans may be rooted in a similar compromise. The link between the protection of the nation state's borders and the smuggling of and trafficking in humans merits further research. ${ }^{363}$

We should learn from the past, and not merely exploit it for emotional gain. The use made thus far of the trans-Atlantic slave trade in the fight against human trafficking has, in a sense, been self-protective of "modern" humanity's and the developed world's sense of self and willful innocence. It serves to prevent deep understanding that the world and human-to-human exploitation may not have changed as much as we would like to believe since the era of the trade in Africans. It serves to protect us from understanding that, like the consumers of the past, we are dependent on the abhorrent exploitation of others. It is easier to characterize traffickers as greedy, rather than profit-seeking, as aberrant, rather than of a piece with the economic structure within which we exist daily. But it would be impossible and irresponsible to ignore the cruel irony of anti-trafficking rhetoric that exploits the imagery of the trans-Atlantic slave trade alongside willful innocence regarding the trade's continued structural effects in the United States and around the globe.

From the comparison of fundamental structural legal and economic similarities and dissimilarities between the trans-Atlantic slave trade and the modern traffic comes a deeper understanding. That understanding should lead to a more comprehensive approach to the elimination of the modern traffic in human beings that confronts head-on the social, political and economic forces that continue to sustain it.

361 In his seminal work, Slavery and Social Death, Orlando Patterson discusses the various mechanisms of and justifications for slavery throughout human history. His analysis and that of Suzanne Miers - in her work SLAvery IN THE TwENTIETH CENTURY - illuminate the reality of slavery as an integral ongoing part of human life that, in historical terms, has only recently been condemned.

362 Derrick Bell, Prologue: The Chronicle of the Constitutional Contradiction, in The Derrick Bell Reader, supra note 181, at $17-22$.

${ }^{363}$ For example, it is well-established that the trafficking in humans from Central and Eastern Europe increased in tandem with the tightening of Western European borders and the immigration and refugee laws stimulated by the fall of the Soviet Union. 
